\title{
CERCETĂRILE ARHEOLOGICE PREVENTIVE DIN AȘEZAREA ROMANĂ DE LA ȘIBOT, PUNCTUL ,ÎN OBREJ” (JUD. ALBA) - CONSIDERAȚII PRELIMINARE ${ }^{1}$
}

\author{
Adela BÂltâc, Paul Damian, Virgil Apostol, Alina Streinu, AleXandra Dolea, \\ IOANA PARASCHIV-GRIGORE, EUGEN PARASCHIV-GRIGORE, \\ CORINA NICOLAE, BOGDAN VOICU
}

\section{PREVENTIVE ARCHAEOLOGICAL RESEARCHES ON THE ROMAN SETTLEMENT AT SIBOT-ÎN OBREJ (ALBA COUNTY). PRELIMINARY CONSIDERATIONS}

Due to the construction of the Orăștie-Sibiu Motorway 1 (section 1 Orăștie-Sebeș) preventive archaeological excavations were made from March to October 2012 at Șibot- $\hat{I}$ Obrej. They identified a habitat from Roman times (PI. III, IX), comprising both a residential area (settlement) and a funerary adjacent area (necropolis). Most of the site was occupied by the settlement, throughout these archeological excavations was possible to establish its Western, Eastern and Southern limits, while the Northern one is situated outside the motorway's perimeter. The settlement was crossed from East to West by a road (PI. XVII), oriented NNE-SSW, passing, most likely North to the necropolis (similar direction with the National Route 7). Parts of a Roman road were investigated as well as two streets and 17 buildings lined along the road, but some of them also having direct street access. These buildings with various sizes and individual planning were investigated fully or partly because some were placed under the embankment of the National Route 7. All buildings were oriented according to the streets, NNW-SSE, all of them being rectangular, and divided into several rooms (PI. XII-XV). The construction technique is similar for most buildings, namely river stones (rare shale, limestone and tiles) bound with mortar (for the main house) and clay (for the dependencies). Functioning floor levels were made of clay or, less commonly, with tiles. Some rooms had heating places, and the buildings were covered with various tiles. The buildings were provided with dependencies, best defined by the term courtyards, which were paved with gravel. Two complex buildings stand apart as having public use, one being the baths of the settlement, and the second a public space (forum?/conciliabulum?). On the entire surface of the settlement, three chronological moments were detected, but some features have only two, while other revealed several phases. In the necropolis the archeological excavations was possible to establish its eastern and western limits, partially the southern and the northern one. There were investigated 210 funerary complexes, of which 164 cremation tombs, the rite cannot be determined in 46 cases because of the poor conservation status. The orientation of tombs reveals no major differences, finding, with few exceptions, a predilection for a NE-SW axis (about 95\% cases). In some situations were observed a series of exterior structures adjacent to the graves, namely three graves placed inside a circular enclosure (a so-called "ring" type structure), other 11 tombs situated inside a small rectangular enclosure and 7 graves covered by a funerary tumulus (mound). The small number of exterior arrangements is probably due to the poor state of conservation of the entire necropolis. The archaeological the material is still being processed so until its completion, preliminary dating of the settlement and necropolis falls into the $2^{\text {nd }}$ century to the first half of the $3^{\text {rd }}$ century AD.

KEYWORDS: settlement, necropolis, residential buildings, public spaces, Roman era, Dacia. CUVINTE CHEIE: așezare, necropolă, locuințe, spații publice, epoca romană, Dacia.

\section{INTRODUCERE}

Posibilitatea existenței unui sit arheologic în punctul „În Obrej", pe raza localitătii Șibot (jud. Alba) a fost semnalată pentru prima dată în literatura de specialitate în anul $2011^{3}$. Concomitent ${ }^{4}$, în

\footnotetext{
${ }^{1}$ La cercetările arheologice din teren au mai participat Cătălina Neagu, Ionuț Bocan, Alexandru Raţiu, Mihai Vasile, Irina Ene, Emil Dumitraşcu, Marius Streinu, Andra Samson, Daniel Ene, Mihai Duca, Edmond Silviu Ene, Sebastian Dobrotă, Florentin Munteanu, Nicolae Stoica, Gică Băeștean.

2 Toponimul obrej, obrejă, obreje, foarte des întâlnit în toponimia din România, pare a desemna la origine ,,colină, deal, ridicătură de pământ" (Iordan 1963, 33). Localnicii din Șibot, cu care am discutat, nu cunoșteau un toponim anume pentru punctul în cauză, însă acesta apare pe hărți topografice diverse și militare, fie sub forma „Obreje”, fie sub forma „în Obrej”. Deoarece toponimul Obreje pare a mai fi folosit și pentru alte zone de pe raza localității Șibot (Popa 2011, 624 și fig. 151) vom utiliza toponimul „In Obrej” pentru a nu se crea confuzii.

${ }^{3}$ Popa 2011, 362.

${ }^{4} \mathrm{Nu}$ cunoaștem momentul exact din anul 2011 al apariției publicației citată anterior, dar faptul că în aceasta este folosită o fotografie aeriană dintr-un zbor datat 23.06.2011 (Popa 2011, 819, fig. 154), conduce la concluzia că lucrarea a apărut
} 
toamna aceluiași an, în cadrul etapei de evaluare arheologică de teren a Programului Național de Cercetare „Autostrada”, efectuată de către o echipă de specialişti ai Muzeului Național de Istorie a României ${ }^{5}$, au fost realizate și secțiunile de sondaj (PI. II/2), care indicau o zonă de habitat rural din epoca romană ${ }^{6}$, între km 9+650-10+150 ai lotului 1 din sectorul Orăștie-Sebeș (km 0-24+100), parte a Autostrăzii 1 (Orăștie-Sibiu). Deși pe raza satului Șibot erau menționate anterior ${ }^{7}$, în literatura de specialitate (PI. I/2), mai multe puncte cu potențial arheologic, situl din punctul „În Obrej” a fost identificat cu certitudine doar odată cu evaluarea de teren din toamna anului 2011. Trebuie menționat de la început faptul că evaluarea arheologică de teren ${ }^{8}$ a reușit să delimiteze spațial (PI. II/2), cu foarte mare finețe, zona de habitat (chiar dacă nu a reuşit să evidenţieze şi amploarea acestei locuiri). Atât etapa de evaluare de teren, cât și cercetarea arheologică preventivă a sitului au fost determinate de construirea autostrăzii pe acest segment ${ }^{9}$. Evaluarea arheologică (teoretică ${ }^{10}$ şi de teren) a potenţialului arheologic al zonei menționate, respectiv diagnosticul arheologic intrusiv, s-au desfășurat în perioada octombrie-decembrie 2011. Cercetarea arheologică preventivă s-a realizat în perioada lunilor martieoctombrie 2012 și a fost realizată în conformitate cu legislaţia în vigoare în domeniul protejării patrimoniului arheologic ${ }^{11}$.

Caracterul cercetării arheologice a impus ca obiectiv principal al echipei de specialiști investigarea exhaustivă a tuturor vestigiilor identificate în zona suprapusă direct de lucrările direct de lucrările de construire a autostrăzii. Cercetările arheologice cu caracter preventiv, efectuate în primăvara-toamna 2012, de-a lungul a 31 de săptămâni, au confirmat prezenţa potenţialului arheologic semnalat anterior prin diagnosticul de teren ${ }^{12}$, fiind identificate şi cercetate peste 300 de complexe arheologice, distribuite pe o suprafaţă de cca $28.000 \mathrm{mp}$ din cei peste $39.000 \mathrm{mp}$ investigați, între km 9+650 și 10+150 ai traseului autostrăzii. Astfel, cercetările arheologice au identificat (PI. III,

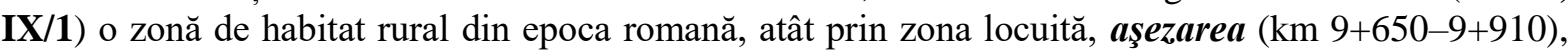
cât şi prin zona funerară aferentă acesteia, necropola (km 9+920-10+054). Situl se delimita între km 9+650-10+054, fiind traversat de Drumul Național 7, aproximativ pe direcția E-V, ceea ce a condiționat modul de abordare al cercetării. De asemenea, metoda de cercetare a avut în vedere starea de conservare a sitului. Scurgerea apelor pluviale, urmând panta naturală spre râul Mureş (de la S la N), aluviunile aduse de râul Cugir, poate chiar şi de Mureş, construirea DN7, cultivarea viţei-de-vie în zona necropolei, excavarea anterioară a dealului „Ţelinile Şibotului” (PI. IV/2, V/2), practicarea agriculturii intensive, folosirea ca cimitir de animale a zonei așezării (PI. IV/1), introducerea fibrei optice, a unei conducte de gaze (PI. IV/3) şi diverse alte intervenții antropice necunoscute au dus la deteriorarea vestigiilor arheologice, încât unele dintre complexe au fost surprinse într-o stare de conservare precară.

spre sfârșitul anului 2011, ceea ce face cele două informații să fie practic accesibile simultan și independente una de cealaltă.

${ }^{5}$ Damian et alii $2012,280$.

${ }^{6}$ În raportul realizat atunci (Damian et alii 2012, 280), se preciza și posibilitatea existenței unui nivel databil în epoca La Tène, element neevidențiat în cercetările arheologice preventive ulterioare.

7 Téglás 1902, 149; Tudor 1968, 135; Lipovan 1984, 459-465; RAA, 180-181; Ardevan 1993 (1996), 19; Popa 2002, 188; Popa 2011, 352-370. Pentru o localizare a acestor puncte, vezi Popa 2011, 693-695.

${ }^{8}$ Au fost trasate și investigate 27 de unități de cercetare (Pl. II/2), de dimensiuni variabile, atât la nord, cât și la sud de DN 7 , conform cu Raportul final de evaluare al potențialului arheologic pe traseul Autostrăzii Orăștie - Sibiu, Lot 1, OrăștieSebeș, p. 13, din Arhiva MNIR, Secția Arheologie Preventivă.

${ }^{9}$ Firma STRABAG S.R.L. a solicitat Muzeului Naţional de Istorie a României în scopul cercetării și întocmirii documentaţiilor necesare, în conformitate cu cerinţele legale aplicabile; astfel, între cele două părţi s-a încheiat un contract de prestări servicii în vederea efectuării cercetărilor arheologice preventive pe traseul viitoarei autostrăzi 1 (Orăştie-Sibiu), lot 1 Orăştie-Sebeş $(\mathrm{km} 0 \rightarrow \mathrm{km}$ 24+100).

${ }^{10}$ Evaluarea teoretică pe tronsonul amintit a fost efectuată, într-o perioadă anterioară (2010) evaluării din teren (2011), de către specialiștii Muzeului Civilizației Dacice și Romane, Deva și Muzeului Național al Unirii, Alba-Iulia.

${ }^{11}$ O.G. nr. 43/2000, cu modificările ulterioare și OMCC nr. 2392/2004, în baza Autorizației de Diagnostic Arheologic nr. 206/2011 și a Autorizațiilor de Cercetare Arheologică Preventivă nr. 35/2012, 144/2012, 226/2012 și 255/2012 eliberate de Ministerului Culturii și Patrimoniului Național.

${ }^{12}$ Situl nu a fost semnalat în etapa de evaluare teoretică. 


\section{DATE GEOGRAFICE}

Localitatea Şibot, situată pe malul stâng al râului Mureş, la vest de râul Cugir, se învecinează la nord cu comuna Ceru-Băcăinţi, la sud cu satul Vinerea, la est cu comunele Săliştea şi Blandiana şi la vest cu satul Aurel Vlaicu ${ }^{13}$ (Pl. I/1). De asemenea, este amplasată la 27 km de Alba Iulia (anticul Apulum), la $13 \mathrm{~km}$ de Cugir, la $12 \mathrm{~km}$ de Orăştie şi la 76 km de Ulpia Traiana Sarmizegetusa. Din punct de vedere administrativ, Șibot este o comună din care fac parte localitățile Șibot, Balomiru de Câmp, Băcăinți și Sărăcsău.

Din punct de vedere geomorfologic ${ }^{14}$, în zona sitului, depozitele sedimentare sunt reprezentate prin aluviunile de vârstă holocenă din lunca râului Mureş, constituite din nisipuri și pietrişuri, respectiv travertin. În zona situată la sud de localitatea Geoagiu, sunt întâlnite depozite de travertin. Depozitele pleistocene din alcătuirea teraselor inferioară, medie și superioară sunt alcătuite, de asemenea, din pietrișuri și nisipuri, cu vârste atribuite celor trei etape ale pleistocenului superior (de început, mediu și final). Depozitele Neogenului sunt suprapuse discordant și sunt reprezentate prin depozitele Tortonianului, alcătuite din marne, marne tufacee, tufuri și calcare, suprapuse la rândul lor, discordant, de depozite ale Sarmațianului - marne, marne nisipoase și marne argiloase. După cum rezultă din secțiunile geologice, albia râului Mureș este tăiată, în această zonă, în depozite ale Tortonianului și ale Burdigalianului (Sarmaţian inferior).

Punctul „În Obrej” este amplasat între satele Şibot şi Balomiru de Câmp, la cca 1,50 km est de localitatea Şibot, $0,50 \mathrm{~km}$ est de malul actual al râului Cugir şi la aproape $3 \mathrm{~km}$ sud de cursul actual al râului Mureş (PI. II/1). Zona în care se află situl este mărginită la sud de dealul cunoscut sub numele de „Ţelinile Şibotului ${ }^{15}$ ”, deal care se dezvoltă între râul Cugir şi pârâul Sărăţii şi care dispune de un platou vast, folosit încă şi în zilele noastre ca zonă de decolare pentru aeronave de capacitate mică. Acest deal pare să fi suferit multiple intervenţii antropice, printre care sunt de amintit terasarea pentru cultivarea viţei-de-vie, pe latura de nord-est, „tăierea” traseului DN7 (pe direcţia E-V), excavarea în terase (PI. IV/2, V/2), în partea de nord-vest, a unei cantităţi uriaşe de sediment, folosit la construirea digurilor şi la regularizarea cursului râului Cugir. Astfel, la debutul cercetării noastre, zona de la sud de DN7 se prezenta, în partea estică, sub forma unei terase nu foarte înalte - $227 \mathrm{~m}$ altitudine (PI. V/1), o pantă abruptă şi puternic erodată de apele pluviale, în zona de sud (PI. V/2) și o mică zonă plană (cca $80 \times 200 \mathrm{~m}$ ), între panta abruptă şi terasamentul DN7. La nord de DN7 întreaga zonă până la râul Mureș ${ }^{16}$ era una plană și netedă $(\mathbf{P I}$. V/3), cu o pantă uşor descendentă, spre râul Mureş, deci de la $\mathrm{S}$ la N.

\section{SCURT ISTORIC AL ZONEI}

Prima menţiune documentară a localității Şibot datează din anul 1330, când apare sub numele de Kunyrthu, satul fiind apoi menționat, sub diferite toponime (Kenyer, Kunyrthu, Alkunir, Alkényer, Sibeth, Jebă $t^{17}$ ) în diverse documente pe parcursul Evului Mediu și a epocii premoderne ${ }^{18}$. Cel mai important moment al istoriei zonei este legat de Bătălia de la Câmpul Pâinii, din anul 1479, avându-1 ca principal erou pe Paul Kinizsi (Pavel Chinezu), comitele de Timişoara. Această luptă se presupune

${ }^{13} \mathrm{http}: / /$ www.primaria-sibot.ro/Sibot_cadrul-geografic-107.html

14 Descriere geomorfologică a fost realizată de dl. dr. Constantin Haită, sedimentolog (MNIR). Referință bibliografică Dessila-Codarcea 1968, foaia Orăștie.

15 Acest punct este cunoscut în literatura de specialitate și sub forma „În Țelini” sau „La Țelini”, iar cercetările perieghetice au pus în evidență posibilitatea existenței aici a unor habitate aparținând culturii Coțofeni, epocii bronzului timpuriu și culturii Wietenberg; vezi Popa 2011, 694.

${ }^{16}$ La aproximativ $0,50 \mathrm{~km}$ nord de DN7 se află terasamentul liniei de cale ferată Vinţu de Jos-Deva, care modifică aspectul plan al peisajului antic.

${ }^{17}$ Despre etimologia numelui și evoluția așezării, vezi Popa 2011, 439, 454-457.

18 Este de menționat că pe traseul A1 Orăştie-Sibiu, tronsonul Orăştie-Sebeş, între km 8+650-8+950, în apropierea intersecţiei DN7 cu bifurcaţia spre oraşul Cugir, a fost identificată şi cercetată o aşezare medievală, databilă pe parcursul secolelor XII-XV. Pentru rezultatele preliminare vezi Samson et alii 2014, 327-362. 
că a avut loc în zona hotarului estic al satului, unde culoarul Mureşului se îngustează şi se apropie de malul drept al Cugirului ${ }^{19}$.

Perimetrul comunei Șibot, ca de altfel întreaga zonă a văii Mureșului în porțiunea SebeşOrăştie, este unul care cunoaște o locuire intensă în aproape toate epocile istorice, aici fiind repertoriate numeroase puncte de interes arheologic ${ }^{20}$. Câteva dintre punctele repertoriate anterior, dar și altele noi, au fost confirmate arheologic prin cercetări preventive prilejuite de necesitatea construirii lotului 1 al Autostrăzii Orăștie-Sebeș ${ }^{21}$, în anul 2012.

În ceea ce privește epoca romană (PI. I/2), pe raza comunei Șibot sunt semnalate în diverse lucrări de specialitate mai multe puncte de interes arheologic. Prima mențiune datează din anul $1866^{22}$, din momentul construirii liniei ferate ${ }^{23}$, ocazie cu care câteva artefacte databile în epoca romană sunt predate Gimnaziului Evanghelic din Sebeș ${ }^{24}$. La sfârșitul secolului al XIX-lea ${ }^{25}$, materiale ceramice, tegulare (una cu ştampila $A S C L E P{ }^{26}$ ), numismatice şi resturi de clădiri ${ }^{27}$ sunt reperate în sudul aşezării de la Şibot ,în apropierea fostului oficiu poștal ${ }^{28}$ ", ceea ce i-a determinat pe mai mulți specialiști să identifice în această zonă o așezare de tip vicus sau o villa ${ }^{29}$. În anul 1979, minore investigații de teren ${ }^{30}$ adaugă două noi puncte de interes pentru epoca romană: ,pe partea stîngă $a$ liniei C.F.R. Șibot-Cugir ${ }^{31}$ " și punctul Baltă , în spatele fermei zootehnice a C.A.P. Șibot ${ }^{32}$ ", în ambele puncte fiind menționate fragmente ceramice, materiale tegulare (una purtând ștampila $L E G$ XIII $G$ ) și litice, un cuptor de ars material ceramic și alte artefacte din epoca romană. În anul 1985, în ,păşunea din hotarul sud-vestic al comune ${ }^{33}$ sunt descoperiți doi ,aurei” emiși de împăratul Nero, între anii 6368 p. Chr. ${ }^{34}$ Următoarea mențiune este din anul 1987, când la Şibot este semnalată o villa ${ }^{35}$. Noi puncte de interes de pe raza comunei Șibot, aflate în hotarele satelor Balomiru de Câmp, Șibot, Sărăcsău și Băcăinți, se adaugă în anul 2011 și se datorează cercetărilor de teren întreprinse de Cristian Popa $^{36}$. Cu această ocazie, pe lângă noile informații oferite asupra punctelor deja cunoscute Cânepişte ${ }^{37}$ și Baltă, sunt adăugate noi puncte cum sunt cele de la Aușele, În Țelini și, așa cum menționam la începutul rândurilor de față, Obreje $^{38}$. Mai trebuie adăugat că informaţiile despre potenţialul arheologic din raza comunei Șibot au fost completate recent, cu ocazia cercetărilor arheologice preventive de pe traseul A1, Orăştie-Sibiu, tronsonul Orăştie-Sebeş, între km $11+250$ $11+600$, pe raza satului Balomiru de Câmp, unde au fost cercetate vestigii din epocă romană, cel mai probabil fiind vorba despre o porţiune dintr-o villa rustica ${ }^{39}$.

\footnotetext{
${ }^{19}$ Popa 2011, 587-608.

${ }^{20}$ Cum sunt aşezările preistorice de la Pianu de Jos, Tărtăria, Balomiru de Câmp, Cugir, Șibot, Vinerea, Blandiana, Sărăcăsău, vezi RAA fiecare s.v.; cu completările și corecturile pentru cele de pe valea Cugirului la Popa 2011, passim.

${ }^{21}$ Pentru siturile cercetate pe lotul 1, vezi Damian et alii 2013a, 228 (complexe aparţinând mai multor culturi preistorice); Borş et alii 2014 (complexe aparținând mai multor culturi preistorice); Samson et alii 2014 (secolele XII-XV); Dumitrașcu, Rațiu, Dolea 2013 (epocă romană și medievală timpurie); Borș et alii 2013 (Hallstatt mijlociu); Simion et alii 2014 (cultura Coțofeni, epoca romană, post-romană și medievală timpurie); Damian et alii 2013b, 223-224 (complexe aparținând perioadei neolitice, epocii bronzului și așezare medievală); Bem 2015 (locuire eneolitică); Bem et alii 2013 (locuire Coțofeni și Wietenberg).

22 RAA, 181, vezi și observația lui Cristian Popa față de această informație (Popa 2011, nota 2023).

${ }^{23}$ Linia ferată Orăștie-Sebeș trece prin zona de sud a localităților Șibot și Balomir.

${ }^{24}$ Popa 2011, 352.

${ }^{25}$ Popa $2011,352$.

${ }^{26}$ IDR III/3, nr. 277a.

${ }^{27}$ IDR III/3, p. 277.

28 Téglás 1902, 149: „a volt postaépület közelében”. Fostul sediu al poștei este bine marcat pe hărțile iosefine în punctul de bifurcatie cu drumul care merge spre localitatea Vinerea.

${ }^{29}$ Tudor 1968, 135; IDR III/3, p. 277; Lipovan 1984, p. 459; RAA, 181.

${ }^{30}$ Lipovan 1984, p. 459-465;

${ }^{31}$ Lipovan 1985, 459 și fig. 1, punctul 2, unde se face și mențiunea existenței unui drum de factură romană.

${ }^{32}$ Lipovan 1985, 459 și fig. 1, punctul 3.

${ }^{33}$ Suciu, Moga 1989, 168.

${ }^{34}$ Ardevan 1993, 19.

${ }^{35}$ Mărghitan 1987, 64. Autorul nu menționează detalii care să conducă la localizarea obiectivului în teren, deși din context reiese că au avut loc cercetări în teren: „... în toate obiectivele similare investigate prin săpături...”.

${ }^{36}$ Popa 2011, 353, 358.

${ }^{37}$ Aceste punct este de identificat cu cel amintit de Téglás și anume zona vechiului han de poștă, vezi supra nota 26.

${ }^{38}$ Popa 2011, 359-362.

${ }^{39}$ Dumitrașcu, Rațiu, Dolea 2013, 103-140.
} 


\section{METODOLOGIA DE CERCETARE}

Dată fiind particularitatea cercetării, configuraţia actuală a terenului şi suprafaţa mare (PI. VI) delimitată în cursul evaluării de teren ca având potenţial arheologic $(500 \times 70 \mathrm{~m})$, cercetarea a demarat la sud de DN7, de la est la vest (deci de la km 10+150 descendent), pentru delimitarea cât mai exactă a sitului în acest perimetru (PI. VII). Astfel, pe terasa dintre km 10+150-9+920 au fost efectuate, cu utilaje mecanice, 11 secţiuni de control stratigrafic (numerotate cu cifre în ordinea cercetării, S001S011), perpendiculare pe traseul A1, amplasate la distanţe variabile între ele (între $20 \mathrm{~m}$ şi $40 \mathrm{~m}$ ), cu dimensiuni cuprinse între 12-70 m lungime, 1,70-2,30 m lăţime şi 0,75-1,80 m adâncime. Ulterior, sa decapat mecanic stratul vegetal între aceste secţiuni, rezultând suprafeţe (denumite în funcţie de secţiunile alăturate, Suprafaţa 1, 2 etc.) de 20-60 × 70 m (lăţimea autostrăzii). Complexele, identificate la decaparea mecanică și prin metode clasice, au fost cercetate exclusiv manual. Prin cele 11 secţiuni şi 12 suprafeţe rezultate, s-a reuşit delimitarea unei necropole de incineraţie din epoca

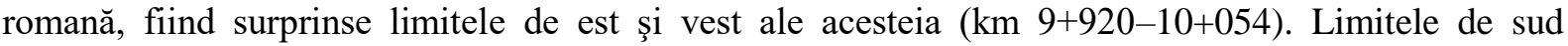
(aceasta pare să depăş̧ească limita sudică a A1) şi nord (zona nordică a terasei este puternic perturbată de un drum de ţară şi de construirea DN7) au fost identificate parţial. Cele 228 de complexe arheologice cercetate, purtând litera N (de la necropolă) în faţă, au primit sigle numerice crescătoare, în ordinea descoperirii; în funcţie de situaţia specifică din teren, unele complexe au fost suplimentar catalogate cu o siglă alfabetică la final (de exp. CPL N083a, N083b etc.). În perimetrul dintre panta şi poalele terasei şi la baza dealului „T, Telinele Şibotului”, km 9+920-9+800 sud DN7, au fost realizate o secţiune şi trei suprafețe cu dimensiunile cuprinse între 45-90 m lungime, 1,50-5/60 m lăţime (configuraţia terenului şi perimetrul solicitat de beneficiar pentru cercetarea arheologică au impus forma şi dimensiunile acestor secţiuni şi suprafeţe). Acestea din urmă au fost numerotate în ordinea deschiderii, cu sigle numerice precedate de litera A (aşezare). Una dintre suprafeţe (Suprafaţa A0), prin lărgirea spre est, s-a intersectat cu Suprafaţa 006 (din necropolă), astfel s-a acoperit întreaga arie, delimitând la est aşezarea. În acest perimetru au fost identificate şi cercetate 14 complexe arheologice (precedate de litera A fiind înregistrate cu sigle numerice în ordinea descoperirii; în funcţie de situaţia specifică din teren, unele complexe au primit şi sigle alfabetice la final). În perimetrul de la nord de DN7 (km 9+930-9+650) au fost deschise cinci secțiuni, perpendiculare pe traseul A1, cu dimensiuni cuprinse între $17-73 \mathrm{~m}$ lungime, $1,50-1,70 \mathrm{~m}$ lăţime şi $0,80-1,80 \mathrm{~m}$ adâncime, aflate la distanţe variabile între ele $(35-80 \mathrm{~m})$. Ulterior, s-a trecut la decaparea mecanică a stratului vegetal între aceste secţiuni, rezultând suprafeţe, numerotate în continuarea celor de la sud de DN7 (respectiv Suprafeţele A3 şi A4). Complexele arheologice identificate în aceste suprafeţe au fost cercetate manual; în anumite locuri au fost practicate re-decapări mecanice. În vederea cercetării integrale a complexelor arheologice identificate, a fost decapată şi zona situată la sud de A1 până în DN7, zonă expropriată, rezultând o nouă suprafaţă (Suprafaţa A5) de $16 / 40 \times 80 \mathrm{~m}$. În perimetrul de la nord de DN7 au fost identificate şi cercetate 63 de complexe arheologice.

Principalele constrângeri existente cu privire la derularea cercetărilor arheologice preventive ${ }^{40}$ (PI. VIII) au fost actualizarea pe parcurs a proiectului tehnic de construire a autostrăzii (cum ar fi demararea construirii podului peste DN7) şi de condiţiile meteo.

\section{DATE GENERALE PRIVIND STRATIGRAFIA SITULUI}

Aşa cum se evidenţiază şi din cele prezentate mai sus, din punct de vedere geomorfologic situl suprapune două zone, o terasă (nu foarte înaltă, 227 m altitudine) şi o zonă plană, zone cu morfologie stratigrafică diferite, cea a așezării și cea a necropolei. In situ, aceste unități sunt separate de traseul DN7.

\footnotetext{
${ }^{40}$ Programul de lucru a fost de 10 ore pe zi, șase zile pe săptămână, pe teren fiind prezenți, în medie, 5-6 arheologi pe zi, în situații speciale 10-12, iar forța de muncă în primele 2 luni a constat în 20 muncitori zilnic, ulterior o medie de 50-60 muncitori pe zi, în cazuri speciale și doar pentru perioade scurte de timp 70-100 muncitori pe zi.
} 
Stratigrafia generală a zonei este prezentată într-o ordine inversă a depunerilor sedimentare, pornindu-se de la stratul superior către bază. $\mathrm{Cu}$ anumite excepţii generate de perturbările datorate permanentei intervenţii antropice şi de configuraţia geomorfologică specifică zonei, stratigrafia generală a sitului este următoarea:

\section{Așezare (Pl. X):}

1. Sol vegetal (orizontul organic al solului actual), cu o grosime variabilă între $0,05-0,20 \mathrm{~m}$, bruncenuşiu, nisipos, omogenitate moderată; are în compoziţie pietre de mici dimensiuni, resturi organice, fragmente ceramice, artefacte din epoca romană, modernă sau contemporană;

2. Nivel de sedimente galben sau brun-negricios, cu grosime variabilă între $0,30-0,80 / 1,00 \mathrm{~m}(\mathrm{cu}$ depunere mai consistentă spre nord), conține concentraţii siltice (ridicate), rocă demineralizată, oxizi de fier, resturi organice, reprezentând niveluri de depuneri aluvionare, în straturi succesive ${ }^{41}$;

3. Nivel brun-cenuşiu, cu grosimea cuprinsă între $0,15-0,30 / 0,82 \mathrm{~m}$, care conţine fragmente ceramice şi tegulare, artefacte diverse din epoca romană, pietre de râu, şisturi şi calcare, reprezentând un strat de cultură cu până la trei momente ocupaționale;

4. Nivel de sedimente negru, lutos, compact, cu grosime surprinsă între $0,30-0,80 / 1,54 \mathrm{~m}$, ce are în compoziţie pietre de mici dimensiuni, concreţiuni calcaroase, oxizi de fier, resturi vegetale specifice solului aluvionar - fără urme de intervenţie antropică.

Necropolă (PI. XI):

1. Sol vegetal (orizontul organic al solului actual), cu o grosime variabilă între $0,05-0,20 \mathrm{~m}$, brunmaroniu, nisipos, omogenitate moderată; are în compoziţie pietre de mici dimensiuni, resturi vegetale, fragmente ceramice, potcoave şi cuie din epocă modernă sau contemporană;

2. Nivel de sedimente, brun-negricios, de la cota de $-0,20$ m până la $-0,30$ m; textură nisipoasă, friabil, în compoziţie are resturi organice, pietricele, concentraţii de oxizi de fier, fragmente ceramice, atât moderne, cât şi din epoca romană (acestea din urmă poziţionate îndeosebi la baza stratului), cărbune milimetric şi pământ ars. Trebuie menţionat faptul că, în partea de sud şi vest a pantei, nivelul 2 are o grosime mai mică sau lipseşte, astfel, complexele apar imediat sub nivelul vegetal sau la adâncimi de până la 0,15 m;

3. Nivel de sedimente, galben-maroniu, de la cota de $-0,30 \mathrm{~m}$ la $-1,80 \mathrm{~m}$; în acest caz, se observă variaţii de ordin cromatic de la galben deschis la galben-roșcat, este atât nisipos, cât şi argilos, compact, are în compoziţie concentraţii de oxizi de fier, fragmente ceramice din epoca romană (poziţionate la partea superioară a nivelului), cărbune milimetric, pământ ars;

4. Nivel de sedimente, galben, lutos, compact, ce are în compoziţie concreţiuni calcaroase - fără urme de intervenţie antropică.

\section{SCURTĂ DESCRIERE A DESCOPERIRILOR}

Amploarea cercetării, numărul mare de complexe arheologice, stadiul preliminar al prelucrării materialului (inclusiv al restaurării), ne determină să considerăm ca fiind preliminare datele pe care leam obținut până acum, de asemenea, să ne rezumăm doar la câteva exemple, pentru a contura o imagine de ansamblu.

\section{$\operatorname{Aşezare~}^{42}$ (PI. III, IX/2)}

Cea mai mare parte a sitului, cum este şi firesc, era ocupată de zona efectiv locuită, respectiv între km 9+910 şi 9+650 (la sud şi nord de DN7). Cercetările arheologice de teren au pus în evidenţă limitele de est, sud şi vest ale aşezării. Limita de nord se află în afara traseului A1. Aşezarea era străbătută de la est la vest de un drum antic (orientat NNE-SSV), al cărui traseu trecea, cel mai

\footnotetext{
${ }^{41}$ Lucru confirmat pe teren şi de dr. Constantin Haită, sedimentolog.

${ }^{42}$ Dată fiind perioada scurtă de la încheierea cercetării, a faptului că prelucrarea materialului este în curs de desfășurare, dar și din dorința de a oferi o imagine coerentă, majoritatea complexelor descrise în acest articol se încadrează în ultima fază de viețuire a așezării. Excepție fac cuptoarele de ars material ceramic, care se încadrează în alt orizont cronologic; acestea au constituit subiectul unui alt articol (Bâltâc, Streinu, Dolea 2017). Pentru o viziune complexă asupra aşezării, aici a fost prezentat un singur cuptor din cele 14 cercetate.
} 
probabil, prin partea de nord a necropolei, având, în cea mai mare parte, acelaşi traseu cu cel al DN7. Pe direcție perpendiculară acestui drum, se conservă cel puțin două străzi ${ }^{43}$ (orientate NNV-SSE) care delimitau insulae în care s-au construit locuințe și dotări publice. Au fost identificate şi cercetate 17 clădiri cu dimensiuni şi configurație planimetrică distinctă și alte 55 de complexe conexe.

\section{Complexul A00744 („Edificiul nr. $3^{45 ”), ~ P l . ~ X V / 1 . ~}$}

Amplasament: km 9+890, la sud de DN7, Suprafaţa A0 şi Suprafaţa 6. Orientare: NNV-SSE.

Dimensiuni (conservate): 8,80 × 11,40 m. Suprafaţă estimată: 100 mp. S-au păstrat două ziduri dintr-o clădire cu plan patrulater. Cele două ziduri sunt conservate la nivelul ultimei asize a fundației, pe alocuri se păstrează doar stratul de pietriș/prundiș folosit ca substrat al fundației. Zidul Z1 (orientare $\mathrm{E}-\mathrm{V}$ ): $\mathrm{L}_{\mathrm{p}}=11,50 \mathrm{~m}, 1=0,60 \mathrm{~m}, \mathrm{~h}_{\max }=0,25-0,30 \mathrm{~m}$, lipsa pietrelor pe o lungime de 1,40 $\mathrm{m}$ indică o posibilă intrare pe această latură; Z2 (orientare N-S): $\mathrm{L}_{\mathrm{p}}=8,50 \mathrm{~m}, 1=0,60 \mathrm{~m}, \mathrm{~h}_{\max }=0,20 \mathrm{~m}$. Inventar: fragmente dintr-o râşniţă din granit. Complexul se afla într-o stare de conservare foarte precară; clădirea, situată în extremitatea estică a așezării, se află la aproximativ $48-50 \mathrm{~m}$ de limita estică a necropolei. Aflat la baza zonei mai înalte, la sud de DN7, scurgerea apelor pluviale și lucrările de terasare din epoca modernă au condus la distrugerea aproape totală a acestui complex.

\section{Complexul A009 („Edificiul nr. 1”), PI. XII.}

Amplasament: km 9+840, la sud de DN7, Suprafaţa A001-002, carourile 19-26, la cca $40 \mathrm{~m}$ vest de complexul A007. Orientare: NNV-SSE. Dimensiuni: 12,45 × 10 m. Suprafaţă estimată: 125 mp. Complexul s-a evidențiat la cota de $-0,20 \mathrm{~m}$ față de nivelul actual de călcare.

Clădire, cu plan rectangular, delimitată de trei ziduri (identificate la nivelul fundațiilor) construite din piatră de râu, legată cu mortar, identificat pe alocuri (la colţul estic şi vestic). Z1 (orientare E-V, dimensiuni: $\mathrm{L}=12,45 \mathrm{~m}, 1=0,60 \mathrm{~m}$, $\mathrm{ad}_{\max }=0,30 \mathrm{~m}$ ), cel mai bine conservat, se păstrează pe înălţimea a trei asize așezate pe un pat de umplutură din pietre de mici dimensiuni. Colțurile construcției erau realizate din cărămidă cu mortar; doar în colțul vestic se păstrează două cărămizi $(0,40 \times 0,28 \times 0,05$ m, respectiv $0,40 \times 0,30 \times 0,05 \mathrm{~m})$, în colțul estic cărămida s-a dislocat, păstrându-se doar amprenta în mortarul de poză $(0,30 \times 0,20 \mathrm{~m})$. Z2 (orientare: N-S, dimensiuni: $\mathrm{Lp}=10 \mathrm{~m}, 1=0,50 \mathrm{~m}, \mathrm{ad}_{\max }=0,20$ $0,30 \mathrm{~m}$ ) se păstrează pe înălțimea a două asize; lipsa pietrelor pe o lungime de $3 \mathrm{~m}$, precum și prezența în această zonă a unei amenajări din pietriș, pot indica o intrare pe această latură a construcției. Z3 (orientare N-S, dimensiuni: $\mathrm{Lp}=8,60 \mathrm{~m}, 1=0,60 \mathrm{~m}, \mathrm{ad}_{\max }=0,30 \mathrm{~m}$ ) se păstrează pe înălțimea maximă a patru asize. Limita sudică a clădirii nu se mai conserva. În interiorul spațiului delimitat de cele trei ziduri, la $2 \mathrm{~m}$ sud de Z1, se conservă un aliniament compus din patru baze rectangulare (dimensiuni între 0,55/0,60 × 0,55/0,60 m) construite din piatră de râu legată cu pământ. Clădirea era acoperită cu țigle și olane, judecând după materialul tegular descoperit, mai ales în zona exterioară de vest și est a clădirii. În interiorul clădirii nu se păstra un nivel de călcare coerent, fiind descoperit doar nivelul de lut în care s-a implantat clădirea. De altfel, în interiorul clădirii au fost descoperite foarte puține piese arheologice. Cel mai probabil că zona din exteriorul clădirii era „pavată”, așa cum indică amenajările din pietriş, pietre de râu (de dimensiuni mici) și fragmente ceramice, foarte bine bătătorite, identificate la nord, vest și est de zidurile clădirii. Inventar arheologic: material ceramic (cupe, dolia, mortaria, oale, amfore, vase de uz comun etc.), obiecte din fier (cuie, piroane, unelte etc.), rar din bronz (ținte, plăcuţe etc.).

Observațiile de ordin stratigrafic indică două momente de ocupare a spațiului, cel descris fiind cel de-al doilea. Din primul moment a fost surprins un cuptor de ars material ceramic, dezafectat, iar apoi zona a fost reamenajată pentru a fi construit complexul descris mai sus.

\footnotetext{
${ }^{43}$ Plecând de la definiția dată de Isidorus (Etymologiarum sive Originum, XV, 1, 12: Vicus autem dictus ab ipsis tantum habitationibus, vel quod vias habeat tantum sine muris) considerăm că termenul de străzi nu este eronat folosit în cazul aşezărilor rurale, chiar dacă acestea nu sunt construite după modelul urban (respectiv nu au sistem de canalizare și nici borduri).

${ }^{44}$ Abrevierile folosite în descrierile care urmează sunt: ad = adâncimea, diam = diametru, ext = exterioară, gr = grosime, $\mathrm{h}=$ înălţimea, int = interioară, $\mathrm{L}=$ lungimea, $\mathrm{l}=$ lăţimea, $\max =$ maximă, $\mathrm{p}=$ păstrată.

${ }^{45}$ Pentru o cât mai bună înregistrare a materialului arheologic, pe parcursul cercetărilor de teren s-a folosit şi o numerotare a clădirilor în funcţie de amplasamentul acestora, ordinea descoperirii şi situaţia specifică din teren (la sud de DN7 s-a folosit termenul de „Edificiu”, iar la nord de DN7 cel de „Clădire”), folosindu-se atât sigle numerice, cât şi alfabetice. Aceste denumiri convenţionale vor fi redate în paranteză pentru fiecare complex în parte.
} 


\section{Complexul A024 („,Clădirea nr. 4”), Pl. XV/2.}

Amplasament: km 9+800 (limita nordică a autostrăzii), la nord de DN7, Suprafaţa A3, cca 22 m nord de complexul A021 („Clădirea nr. 2") şi complexul A022 („Clădirea nr. 3”), probabil aliniată străziii ${ }^{46}$ nr. 1 (complexul A025). Orientare: NNV-SSE. Dimensiuni: 15,20 × 11,80 m. Suprafaţă estimată: $180 \mathrm{mp}$. Clădire cu plan patrulater, compartimentată în patru spaţii. Zidurile, conservate doar la nivelul ultimei asize a fundaţiei, sunt construite din piatră de râu legată cu pământ, pe alocuri se păstrează şi pietrişul/prundişul folosit ca prim strat al fundaţiei. La exterior, spre sud, se păstra substructura unui „pavaj” (compus din pietriş şi pietricele), care era dispus (chiar dacă pe alocuri distrus) între aceasta şi clădirile de la sud. Z1 (orientare $\mathrm{E}-\mathrm{V}$ ): $\mathrm{L}=15,20 \mathrm{~m}, 1=0,50-0,60 \mathrm{~m} ; \mathrm{Z} 2$ (orientare $\mathrm{E}-\mathrm{V}$ ): $\mathrm{L}=15 \mathrm{~m}, \mathrm{l}=0,50-0,55 \mathrm{~m} ; \mathrm{Z3}$ (orientare $\mathrm{N}-\mathrm{S}$ ): $\mathrm{L}=11,70 \mathrm{~m}, \mathrm{l}=0,40-0,46 \mathrm{~m} ; \mathrm{ZA}$ (orientare N-S): $\mathrm{L}=11,80 \mathrm{~m}, \mathrm{l}=0,46-0,60 \mathrm{~m}$; Z5 (orientare $\mathrm{N}-\mathrm{S}$ ): $\mathrm{L}=10,80 \mathrm{~m}$ (interior), $1=0,45$ $0,50 \mathrm{~m} ; \mathrm{Z} 6$ (orientare $\mathrm{E}-\mathrm{V}$ ): $\mathrm{L}=4,80 \mathrm{~m}, 1=0,38-0,44 \mathrm{~m} ; \mathrm{Z} 7$ (orientare $\mathrm{E}-\mathrm{V}$ ): $\mathrm{L}=8,20 \mathrm{~m}, 1=0,45 \mathrm{~m}$. Inventar: obiecte de uz comun (ceramică variată, diverse obiecte din fier şi bronz).

\section{Complexul A025 (,Strada nr. 1”), Pl. XVI/1-2.}

Amplasament: km 9+800, la nord de DN7, Suprafaţa A4, între complexul A022 („Clădirea nr. 3”) şi complexul A026 („Clădirea nr. 5”). Orientare: NNV-SSE. Dimensiuni păstrate: $\mathrm{L}_{\mathrm{p}}=44,80 \mathrm{~m}, 1$ = 2,60 m. Strada era amplasată între două clădiri, traseul acesteia este de la sud la nord, urmând panta naturală. $\mathrm{Nu}$ s-a putut observa traseul integral al acesteia, deoarece spre sud acesta se afla sub terasamentul DN7, iar spre nord s-a conservat foarte puțin. Cel mai probabil că traseul ei pornea din drumul roman, identificat la vest şi a cărui direcție spre sud putea intersecta traseul străzii. În faza a doua se practică o nivelare cu pământ a stratului de dărâmătură rezultat de la prăbuşirea clădirilor adiacente (mai ales material tegular), peste care se aplică piatră de râu. Această fază este mai slab conservată, fiind distrusă și de apele pluviale, care urmau panta naturală spre nord (spre râul Mureș). Inventarul recoltat constă în fragmente tegulare şi ceramice, obiecte diverse din fier şi bronz. În urma sondajelor efectuate s-a constatat că această alee are două faze de construcţie.

\section{Complexul A026 („Clădirea nr. 5”), PI. XIII.}

Amplasament: km 9+790, la nord de DN7, Suprafaţa A4, la cca 2,60 m vest de complexul A022 („Clădirea nr. 3”), aliniată străzii nr. 1 (complexul A025). Orientare: NNV-SSE. Dimensiuni: $40 \times$ $12,60 \mathrm{~m}$. Suprafaţă estimată: $504 \mathrm{mp}$. Clădire formată din două corpuri alăturate.

Corpul $n r .1(12,60 \times 22,68 \mathrm{~m}$, definit de zidurile Z1-Z8, Z11) este compartimentat în cel puţin nouă spaţii, închiderea clădirii spre sud fiind situată sub terasamentul DN7. Zidurile sunt construite din piatră de râu, calcar şi şisturi locale (nefasonate) şi bolovani de mari dimensiuni, legate cu mortar, cel mai adesea primul nivel al fundaţiei constând dintr-un strat de prundiş $(\mathrm{gr}=0,10-0,20 \mathrm{~m})$. Materialul tegular şi şisturile semi-fasonate sunt folosite la prima asiză a elevaţiei. Nivelul corespunzător de funcţionare constă dintr-un strat de lut galben-maroniu bine bătătorit (gr $=0,50-0,60 \mathrm{~m}$ ), pe alocuri întărit cu pietre sau materiale tegulare. Z1 (orientare N-S): $\mathrm{L}=22,50 \mathrm{~m}, 1=0,60 \mathrm{~m}, \mathrm{~h}_{\max }=0,80 \mathrm{~m}$; Z2 (orientare $\mathrm{N}-\mathrm{S}$ ): $\mathrm{L}=22,50 \mathrm{~m}, \mathrm{l}=0,68 \mathrm{~m}, \mathrm{~h}_{\max }=0,52 \mathrm{~m} ; \mathrm{Z} 3$ (orientare $\mathrm{E}-\mathrm{V}$ ): $\mathrm{L}=12,30 \mathrm{~m}, \mathrm{l}=0,65$ $0,70 \mathrm{~m}, \mathrm{~h}_{\max }=0,85 \mathrm{~m}$; Z4 (orientare $\mathrm{E}-\mathrm{V}$ ): $\mathrm{L}=10 \mathrm{~m}, \mathrm{l}=0,54-0,65 \mathrm{~m}, \mathrm{~h}_{\max }=0,73 \mathrm{~m} ; \mathrm{Z} 5$ (orientare $\mathrm{E}-$ $\mathrm{V}): \mathrm{L}=10,90 \mathrm{~m}, 1=0,50-0,60 \mathrm{~m}, \mathrm{~h}_{\max }=0,67 \mathrm{~m} ; \mathrm{Z} 6$ (orientare $\mathrm{E}-\mathrm{V}$ ): $\mathrm{L}=11,50 \mathrm{~m}, 1=0,60-0,70 \mathrm{~m}$, $\mathrm{h}_{\max }=0,77 \mathrm{~m} ; \mathrm{Z7}$ (orientare N-S): $\mathrm{L}=7 \mathrm{~m}, \mathrm{l}=0,50 \mathrm{~m}, \mathrm{~h}_{\max }=0,90 \mathrm{~m} ; \mathrm{Z}^{\mathrm{I}}$ (orientare N-S): L = 1,60 $\mathrm{m}, 1=0,50 \mathrm{~m}, \mathrm{~h}_{\max }=0,77 \mathrm{~m} ; \mathrm{Z7}^{\mathrm{II}}$ (orientare N-S): L $=2,00 \mathrm{~m}, 1=0,42-0,54 \mathrm{~m}, \mathrm{~h}_{\max }=0,30 \mathrm{~m} ; \mathrm{Z7}^{\mathrm{III}}$ (orientare $\mathrm{N}-\mathrm{S}$ ): $\mathrm{L}=1,50 \mathrm{~m}, \mathrm{l}=0,46-0,56 \mathrm{~m}, \mathrm{~h}_{\max }=0,26 \mathrm{~m}$; $\mathrm{Z} 8$ (orientare $\mathrm{N}-\mathrm{S}$ ): $\mathrm{L}=1,60 \mathrm{~m}, \mathrm{l}=0,50$ $\mathrm{m}, \mathrm{h}_{\max }=0,53 \mathrm{~m} ; \mathrm{Z}^{\mathrm{I}}$ (orientare $\mathrm{N}-\mathrm{S}$ ): $\mathrm{L}=2,50 \mathrm{~m}, \mathrm{l}=0,50 \mathrm{~m}, \mathrm{~h}_{\max }=0,20 \mathrm{~m} ; \mathrm{Z}^{\mathrm{II}}$ (orientare $\mathrm{N}-\mathrm{S}$ ): $\mathrm{L}=$ $1,50 \mathrm{~m}, \mathrm{l}=0,50 \mathrm{~m}, \mathrm{~h}_{\max }=0,20 \mathrm{~m} ; \mathrm{Z} 11$ (orientare $\mathrm{E}-\mathrm{V}$ ): $\mathrm{L}=1,70 \mathrm{~m}, \mathrm{l}=0,45 \mathrm{~m}, \mathrm{~h}_{\max }=0,38 \mathrm{~m} ; \mathrm{Z} 11^{\mathrm{I}}$ (orientare $\mathrm{E}-\mathrm{V}$ ): $\mathrm{L}=1,15 \mathrm{~m}, \mathrm{l}=0,50-0,56 \mathrm{~m}, \mathrm{~h}_{\max }=0,30 \mathrm{~m} ; \mathrm{Z}_{1} 1^{\mathrm{II}}$ (orientare $\mathrm{E}-\mathrm{V}$ ): $\mathrm{L}=1,30 \mathrm{~m}, \mathrm{l}=$ $0,40-0,50 \mathrm{~m}, \mathrm{~h}_{\max }=0,39 \mathrm{~m} ; \mathrm{Z}_{1} 1^{\mathrm{III}}$ (orientare $\left.\mathrm{E}-\mathrm{V}\right): \mathrm{L}=1,25 \mathrm{~m}, 1=0,50 \mathrm{~m}, \mathrm{~h}_{\max }=0,18 \mathrm{~m}$.

Corpul $n r .2\left(12,60 \times 16,90 \mathrm{~m}\right.$, definit de zidurile $\left.\mathrm{Z1}^{\mathrm{I}}, \mathrm{Z1}^{\mathrm{II}}, \mathrm{Z2}^{\mathrm{I}}, \mathrm{Z9}-10\right)$ este compartimentat în două spaţii. Zidurile sunt construite din piatră de râu legată cu pământ. Nivelul corespunzător de funcţionare constă dintr-un pavaj din pietriş bătătorit într-un strat de lut, mai bine conservat în spațiul nr. 2. Cel mai probabil, acest corp reprezintă o curte/anexă. $\mathrm{Z1}{ }^{\mathrm{I}}$ (orientare $\mathrm{N}-\mathrm{S}$ ): $\mathrm{L}=5,50 \mathrm{~m}, 1=0,60$

\footnotetext{
${ }^{46}$ Direcția străzii ar indica acest fapt, însă în această zonă este foarte distrusă, păstrându-se doar câteva pietricele.
} 
$\mathrm{m}, \mathrm{h}_{\mathrm{p}}=0,30 \mathrm{~m} ; \mathrm{Z1}^{\mathrm{II}}$ (orientare N-S): $\mathrm{L}=9,60 \mathrm{~m}, 1=0,70 \mathrm{~m}, \mathrm{~h}_{\max }=0,60 \mathrm{~m} ; \mathrm{Z} 2^{\mathrm{I}}=16,90 \mathrm{~m}, 1=0,50 \mathrm{~m}$, $\mathrm{h}_{\operatorname{maxp}}=0,60 \mathrm{~m} ; \mathrm{Z} 9$ (orientare $\mathrm{E}-\mathrm{V}$ ): $\mathrm{L}=12,60 \mathrm{~m}, \mathrm{l}=0,80 \mathrm{~m}, \mathrm{~h}_{\max }=0,25 \mathrm{~m} ; \mathrm{Z} 10$ (orientare $\mathrm{E}-\mathrm{V}$ ): $\mathrm{L}=$ $4,70 \mathrm{~m}, 1=0,64-0,66 \mathrm{~m}, \mathrm{~h}_{\max }=0,40 \mathrm{~m}$.

Pe latura de nord au fost identificate șase „baze” ${ }^{47}$ probabil pentru stâlpi din material perisabil, precum și o cantitate apreciabilă de bucăți de lut (de culoare roșiatică), astfel încât este de presupus existența unei zone anexă acoperită în această parte a complexului.

Observaţiile in situ (mai ales de ordin stratigrafic) indică existenţa a două faze, însă acestea nu sunt sesizabile şi la nivel planimetric. Complexe conexe: A023 (groapă în zona zidurilor Z8-Z8 ${ }^{\mathrm{II}}$ şi Z7 $7^{\mathrm{I}}-\mathrm{Z7}^{\mathrm{III}}$ ); A015 (anexă?). Materialul recoltat constă din material de construcţie (tegular şi obiecte din fier), obiecte de uz comun (ceramică variată, opaiţe, obiecte din sticlă, diverse obiecte din fier, bronz şi os, o râşniţă), material numismatic.

\section{Complexul A027 („Clădirea nr. 7”), PI. XIV.}

Amplasament: km 9+780, la nord de DN7, Suprafaţa A4, la cca $1 \mathrm{~m}$ vest de complexul A026 = „Clădirea nr. 5”). Orientare: NNV-SSE. Dimensiuni: $31 \times 11,10$ m. Suprafaţă estimată: 344 mp.

Clădire cu plan rectangular din care s-au putut cerceta trei încăperi şi o anexă, zona de sud fiind situată sub terasamentul DN7. Zidurile (Z1-Z6), păstrate la nivelul ultimelor asize ale fundaţiei, sunt construite din piatră de râu, rar fragmente tegulare, legate cu pământ. Acestea sunt ridicate pe un strat de distrugere, nivelat cu lut galben-maroniu sau un strat de balast. Anexa $(6,50 \times 2,20 \mathrm{~m})$ este adosată pe latura de nord, iar zidurile (Z7-Z9) s-au conservat până la ultima asiză a fundaţiei. Celelalte componente ale clădirii spre nord sunt foarte slab conservate, de exemplu, latura de vest a curţii (?) se păstra doar prin stratul de prundiş de la nivelul fundaţiei. Observaţiile in situ indică existenţa a trei faze de utilizare a zonei, cea descrisă anterior fiind ultima. Z1 (orientare $\mathrm{N}-\mathrm{S}$ ): $\mathrm{L}=13,10 \mathrm{~m}, 1=0,70$ $\mathrm{m}, \mathrm{h}_{\max }=0,36 \mathrm{~m} ; \mathrm{Z} 2$ (orientare $\mathrm{N}-\mathrm{S}$ ): $\mathrm{L}_{\text {vizibil }}=12,05 \mathrm{~m}, \mathrm{l}=0,68 \mathrm{~m}, \mathrm{~h}_{\max }=0,18-0,29 \mathrm{~m} ; \mathrm{Z3}$ (orientare $\mathrm{E}-\mathrm{V}$ ): $\mathrm{L}=11,10 \mathrm{~m}, \mathrm{l}=0,82 \mathrm{~m}, \mathrm{~h}_{\max }=0,23 \mathrm{~m} ; \mathrm{Z} 4$ (orientare $\mathrm{E}-\mathrm{V}$ ): $\mathrm{L}_{\mathrm{p}}=3,90 \mathrm{~m}, \mathrm{l}=0,63 \mathrm{~m}, \mathrm{~h}_{\max }=0,16$ $\mathrm{m}$; Z5 (orientare $\mathrm{E}-\mathrm{V}$ ): $\mathrm{L}=5,10 \mathrm{~m}, \mathrm{l}=0,65 \mathrm{~m}, \mathrm{~h}_{\max }=0,15 \mathrm{~m}$; $\mathrm{Z6}$ (orientare $\mathrm{N}-\mathrm{S}$ ): $\mathrm{L}=5,96 \mathrm{~m}, \mathrm{l}=0,64$ $\mathrm{m}, \mathrm{h}_{\max }=0,25 \mathrm{~m} ; \mathrm{Z}^{\mathrm{I}}$ (orientare $\mathrm{N}-\mathrm{S}$ ): $\mathrm{L}=1,17 \mathrm{~m}, 1=0,78 \mathrm{~m}, \mathrm{~h}_{\max }=0,12 \mathrm{~m} ; \mathrm{Z} 7$ (orientare $\mathrm{E}-\mathrm{V}$ ): $\mathrm{L}_{\mathrm{p}}=$ $6,50 \mathrm{~m}, 1=0,63 \mathrm{~m}, \mathrm{~h}_{\max }=0,15 \mathrm{~m} ; \mathrm{Z} 8$ (orientare N-S): $\mathrm{L}_{\mathrm{p}}=2,05 \mathrm{~m}, 1=0,20 \mathrm{~m}, \mathrm{~h}_{\max }=0,12 \mathrm{~m} ; \mathrm{Z} 9$ (orientare $\mathrm{N}-\mathrm{S}$ ): $\mathrm{L}=2,20 \mathrm{~m}, \mathrm{l}=0,69 \mathrm{~m}, \mathrm{~h}_{\max }=0,09 \mathrm{~m}$. Complexe conexe: A027a (cuptor de ars material ceramic, cu picior median); A016 (amenajare din pietre). Inventar: material de construcție (tegular şi obiecte din fier), obiecte de uz comun (ceramică diversă, opaiţe, obiecte din sticlă, diverse obiecte din fier, bronz şi os), material numismatic.

\section{Complexul A041 (drum), PI. XVII/1-2.}

Amplasament: km 9+760-9+650, la sud de ampriza autostrăzii până în DN7, Suprafaţa A5. Orientare: NNE-SSV. Dimensiuni dezvelite: $\mathrm{L}_{\max }=100 \mathrm{~m}$ (păstrat în diverse stadii de conservare), $1=$ $12 \mathrm{~m}$. Drumul brăzda așezarea de la est spre vest, din acesta pornește sigur strada nr. 2 (complexul A043), iar la nord de drum se aliniază complexul A031 („Clădirea nr. 6”), complexul A044 („Clădirea nr. 8a”), complexul A045 („Clădirea nr. 8b”), complexul A049 (,zona 4”), complexul A046 (,zona 13"), complexul A029. Au fost decelate două momente constructive, asemănătoare, şi anume straturi succesive de balast (pietriş şi nisip), bătătorit ( $\mathrm{gr}=0,20-0,40 \mathrm{~m}$, faza 1 ; gr $=0,10-0,44 \mathrm{~m}$, faza 2), „bombat” pe centru. Cele două faze se departajează printr-o nivelare cu pământ de culoare cenuşie (gr $=0,15-0,30 \mathrm{~m}$ ). Trebuie menționat că o legătură dintre drum şi strada nr. 2 există numai în prima fază de funcționare a acestora. Inventar: material de construcție (tegular şi obiecte din fier), obiecte de uz comun (ceramică diversă, opaiţe, obiecte din sticlă, diverse obiecte din fier, bronz şi os), material numismatic.

\footnotetext{
${ }^{47}$ Este vorba despre amenajări de formă dreptunghiulară, de mici dimensiuni $(0,20 / 0,30 \times 0,20 / 0,40 \mathrm{~m})$, care constau dintr-un „pat” din pietriş $(g r=0,10-0,30 \mathrm{~m})$ și piatră de râu de dimensiuni mici și medii. Cel mai probabil că în centrul acestei amenajări putea fi un stâlp din lemn, iar pietrele puteau fi folosite la stabilizarea pământului din jurul acestuia.
} 


\section{Complexul A38 (cuptor ${ }^{48}$ ), PI. XVIII/1-2.}

Amplasament: km 9+770, la nord de DN7, Suprafața A4 (clădirea 6). Orientare: N-S. Dimensiuni: cuptor (dim $=1,40 \mathrm{~m}, \mathrm{~h}_{\operatorname{maxp}}=0,31 \mathrm{~m}$, gr $_{\text {pereți }}=0,04-0,12 \mathrm{~m}$ ); picior: $\operatorname{dim}=0,30 \mathrm{~m}, \mathrm{~h}_{\max }=$ $0,32 \mathrm{~m}$; gura alimentare: $\operatorname{dim}_{\operatorname{maxp}}=0,42 \mathrm{~m}, \mathrm{hp}=0,31 \mathrm{~m}$. Cuptor de formă circulară în plan, cu picior central de susținere a solei şi gura de alimentare orientată spre sud. Acesta a fost realizat prin tehnica „lutului cruțat”, iar piciorul construit din fragmente tegulare și lut. Fiind dezafectat din Antichitate nu au fost surprinse elemente legate de solă. După dezafectare, a fost umplut cu material tegular, lut ars și rar fragmente ceramice.

\section{Necropola $^{49}(\mathbf{P I}$. III, IX/1, XIX)}

Aşa cum am menţionat mai sus, în perimetrul km 9+920-10+054 a fost identificată necropola aşezării, fiind surprinse limitele de vest şi est, şi parţial cele de sud şi nord. În cele patru luni de cercetare de teren (martie-aprilie, iulie-august) au fost identificate şi cercetate 228 de complexe arheologice, dintre acestea $210 \mathrm{cu}$ caracter funerar (morminte de incinerație), 164 fiind morminte de incinerație cu ardere pe loc, pentru celelalte 46, din cauza stării precare de conservare, nu s-a putut stabili cu certitudine varianta de rit. De asemenea, au fost identificate mai multe elemente de arhitectură funerară şi o incintă funerară. Inventarul mormintelor este constituit, preponderent, din material ceramic, obiecte din metal, obiecte din sticlă şi varia (os, silex).

Complexul N007 (mormânt de incineraţie, cu ardere pe loc), Pl. XX.

Amplasament: secţiunea S006. Orientare: NE-SV. Dimensiuni: L = 1,33 m; $1=1,00 \mathrm{~m}$; ad = 0,28 m. Groapă de formă rectangulară, cu pereții foarte puțin evazaţi, secțiune albiată, partea inferioară a gropii neregulată. Groapa arsă; arsură discontinuă până la 0,03 m grosime. Fragmentele de os calcinat sunt dispuse în partea inferioară a gropii, compact, fără nicio operaţiune de separare a acestora de resturile rugului (depunere uniformă de lemn ars, în amestec cu fragmente de os calcinat; grosimea acestui strat era până la $0,12 \mathrm{~m}$ ). În partea de est, groapa mormântului era puternic perturbată de o intervenție antropică. Sedimentul de umplutură al gropii era de culoare galben-maroniu, friabil, conţine pigmenţi de cărbune şi pământ ars. Inventar arheologic: două oale (fragmentare), o cană miniaturală (fragmentară), un platou (fragmentar), două cupe (fragmentare) și un vas nedeterminabil ca formă (fragmente corp).

Complexul N021 (mormânt de incineraţie, cu ardere pe loc), PI. XXI, XXX/1.

Amplasament: secţiunea S004. Orientare: NE-SV. Dimensiuni: $\mathrm{L}_{\mathrm{p}}=1,26 \mathrm{~m} ; \mathrm{l}_{\mathrm{p}}=0,46 \mathrm{~m} ; \mathrm{ad}_{\mathrm{p}}=$ $0,30 \mathrm{~m}$. Dimensiuni cameră: $\mathrm{L}_{\mathrm{ext}}=1,26 \mathrm{~m} ; 1_{\text {ext }}=0,46 \mathrm{~m} ; \mathrm{L}_{\text {int }}=0,94 \mathrm{~m} ; 1_{\text {int }}=0,30 \mathrm{~m}$. Dimensiuni cărămizi laturi: $0,40 \times 0,14 \times 0,05 \mathrm{~m}$. Dimensiuni cărămizi partea inferioară: $0,40 \times 0,26 \times 0,05 \mathrm{~m}$. Groapa mormântului era sub forma unei camere rectangulare din cărămidă, cu pereţii drepţi. Se păstra doar etajul inferior. Groapa arsă; arsură discontinuă până la 0,03 m grosime. Fragmentele de os calcinat sunt dispuse în partea inferioară a camerei din cărămidă, compact, fără nicio operaţiune de separare a acestora de resturile rugului. În partea centrală, groapa mormântului era puternic perturbată, de o intervenție antropică. Sedimentul de umplutură al gropii era de culoare cenușie, friabil, conţine pigmenţi de cărbune şi pământ ars. Inventar arheologic: două cupe (fragmentare), fragmente din corp care provin de la trei vase nedeterminabile ca formă, un obiect (belciug?) din bronz. Dintre cărămizile care formau camera, 27 au ștampila $L S$.

Complexul N041 (mormânt de incineraţie, cu ardere pe loc), PI. XXII.

Amplasament: secțiunea S 005. Orientare: NE-SV. Dimensiuni: $\mathrm{L}_{\mathrm{p}}=1,34 \mathrm{~m} ; \mathrm{l}_{\mathrm{p}}=0,60 \mathrm{~m} ; \mathrm{ad}_{\mathrm{p}}=$ $0,32 \mathrm{~m}$. Dimensiuni cameră: $\mathrm{L}_{\mathrm{ext}}=1,34 \mathrm{~m} ; 1_{\mathrm{ext}}=0,52 \mathrm{~m} . \mathrm{L}_{\mathrm{int}}=1,20 \mathrm{~m} ; 1_{\text {int }}=0,48 \mathrm{~m}$. Dimensiuni cărămizi laturi: $0,40 \times 0,28 \times 0,06 \mathrm{~m}$. Dimensiuni cărămizi partea inferioară: $0,48 \times 0,40 \times 0,06 \mathrm{~m}$. Groapă de formă rectangulară, sub forma unei camere de cărămidă. Se păstra doar etajul inferior. Cărămizile de pe laturi sunt aşezate în poziţie verticală. Groapa arsă; arsură discontinuă pâna la 0,03 m

\footnotetext{
${ }^{48}$ Cuptoarele din aşezare sunt subiectul unui alt articol (Bâltâc, Streinu, Dolea 2017).

${ }^{49}$ La prelucrarea materialului din necropolă au participat Adela Bâltâc, Cătălina Neagu și Ionuț Bocan.
} 
grosime. Fragmentele de os calcinat sunt dispuse în partea inferioară a camerei din cărămidă, compact, fără nicio operaţiune de separare a acestora de resturile rugului (depunere uniformă de cărbune de lemn, în amestec cu fragmente de os calcinat). În partea centrală, groapa mormântului este puternic perturbată, de o intervenție antropică. Sedimentul de umplutură al gropii era de culoare galbenmaroniu, friabil, conţine pigmenţi de cărbune şi pământ ars. Inventar arheologic: un platou (fragmentar), un vas nedeterminabil ca formă (fragmente corp), un opaiț, 6 piroane din fier.

Complexul N086c (mormânt de incineraţie, cu ardere pe loc), PI. XXIII, XXX/2-3.

Amplasament: secțiunea S005. Orientare: NE-SV. Dimensiuni: L = 1,80 m; $1=1,04 \mathrm{~m}$; ad = $0,42 \mathrm{~m}$. Groapă de formă rectangulară, cu pereții puțin evazați, secțiune trapezoidală, partea inferioară a gropii neregulată. Groapa arsă; arsură discontinuă până la 0,04 m grosime. Zona limitrofă prezintă urme de ardere. Fragmentele de os calcinat sunt dispuse în partea inferioară a gropii, compact, fără nicio operațiune de separare a acestora de resturile rugului (depunere uniformă de lemn ars, în amestec cu fragmente de os calcinat; grosimea acestui strat era până la $0,10 \mathrm{~m}$ ). În partea centrală și estică, groapa mormântului este puternic perturbată de o intervenție antropică. Sedimentul de umplutură al gropii era de culoare galben-maroniu, friabil, conţine pigmenţi de cărbune şi pământ ars. Inventar arheologic: două farfurii (fragmentare), un bol (fragmentar), fragmente din corp care provin de la două vase nedeterminabile ca formă, un piron (fragmentar) din fier, un fragment silex.

Complexul N133 (mormânt de incineraţie, cu ardere pe loc), PI. XXIV, XXXI/4.

Amplasament: secțiunea S 005. Orientare: NE-SV. Dimensiuni: $L_{p}=1,56 \mathrm{~m} ; \mathrm{l}_{\mathrm{p}}=0,74 \mathrm{~m} ; \mathrm{ad}_{\mathrm{p}}=$ $0,28 \mathrm{~m}$. Dimensiuni cameră: $\mathrm{L}_{\text {pext }}=1,46 \mathrm{~m} ; 1_{\mathrm{ext}}=0,74 \mathrm{~m} ; \mathrm{L}_{\text {pint }}=1,30 \mathrm{~m} ; 1_{\text {int }}=0,42 \mathrm{~m}$. Dimensiuni cărămizi latura de est: $0,40 \times 0,40 \times 0,06 \mathrm{~m}$. Dimensiuni cărămizi partea inferioară: $0,48 \times 0,40 \times 0,06$ $\mathrm{m}$. Mormânt prevăzut cu treaptă, etajul inferior amenajat sub forma unei camere rectangulare din cărămidă. Se păstra doar etajul inferior. Groapa arsă, arsură discontinuă până la $0,03 \mathrm{~m}$ grosime. Fragmentele de os calcinat sunt dispuse în partea inferioară a camerei din cărămidă, compact, fără nicio operaţiune de separare a acestora de resturile rugului (sporadic oase calcinate şi fragmente milimetrice de cărbune). În partea centrală, groapa mormântului era puternic perturbată de o intervenție antropică. Sedimentul de umplutură al gropii era de culoare galben-maroniu, friabil, conţine şi fragmente milimetrice de cărbune şi pământ ars. Inventar arheologic: un vas nedeterminabil ca formă (fragment corp) și un opaiț (fragmentar).

Complexul N135 (mormânt de incineraţie, cu ardere pe loc), PI. XXV, XXXI/1.

Amplasament: secțiunea S 006. Orientare: NE-SV. Dimensiuni: $\mathrm{L}=2,00 \mathrm{~m} ; 1=1,10 \mathrm{~m}$; ad $=0,40$ m. Groapă de formă rectangulară, cu pereții puțin evazați, secțiune albiată, partea inferioară a gropii neregulată. Groapa arsă; arsură discontinuă până la 0,04 m grosime. Fragmentele de os calcinat sunt dispuse în partea inferioară a gropii, compact, fără nicio operaţiune de separare a acestora de resturile rugului (depunere uniformă de lemn ars, în amestec cu fragmente de os calcinat; grosimea acestui strat era până la $0,28 \mathrm{~m}$ ). În partea de vest, groapa mormântului era puternic perturbată de o intervenție antropică. Sedimentul de umplutură al gropii era de culoare galben-maroniu, friabil, conține şi fragmente milimetrice de cărbune şi pământ ars. Inventar arheologic: o cupă (fragmentară), un vas nedeterminabil ca formă (fragmente corp), două piroane (fragmentare) și un obiect neidentificabil din fier.

Complexul N141 (mormânt de incineraţie, cu ardere pe loc), PI. XXVI.

Amplasament: secţiunea S 006. Orientare: NE-SV. Dimensiuni: $\mathrm{L}_{\mathrm{p}}=1,60 \mathrm{~m} ; \mathrm{l}_{\mathrm{p}}=0,78 \mathrm{~m} ; \mathrm{ad}_{\mathrm{p}}=$ 0,40 m. Groapă de formă rectangulară, cu pereții puțin evazaţi, secțiune trapezoidală, partea inferioară a gropii neregulată. Groapa arsă; arsură discontinuă până la 0,03 m grosime. Fragmentele de os calcinat sunt dispuse în partea inferioară a gropii, compact, fără nicio operaţiune de separare a acestora de resturile rugului (depunere uniformă de lemn ars, în amestec cu fragmente de os calcinat; grosimea acestui strat era până la $0,10 \mathrm{~m}$ ). În partea de est, groapa mormântului era puternic perturbată de o intervenție antropică. Sedimentul de umplutură al gropii era de culoare galben-maroniu, friabil, conţine şi fragmente milimetrice de cărbune şi pământ ars. Inventar arheologic: amforă? (fragment perete), platou? (fragment bază), opaiț (ansă). 
Complexul N153 (mormânt de incineraţie, cu ardere pe loc), PI. XXVII.

Amplasament: sectiunea S 006. Orientare: NE-SV. Dimensiuni: $L=1,50 \mathrm{~m} ; 1=1,20 \mathrm{~m}$; ad = 0,46 m. Groapă de formă rectangulară, cu pereţii uşor evazaţi, secţiune trapezoidală, partea inferioară a gropii neregulată. Groapa arsă; arsură discontinuă de până la 0,04 m grosime. Fragmentele de os calcinat sunt dispuse în partea inferioară a gropii, compact, fără nicio operaţiune de separare a acestora de resturile rugului (depunere uniformă de lemn ars, în amestec cu fragmente de os calcinat; grosimea maximă a acestui strat era de $0,12 \mathrm{~m}$ ). Sedimentul de umplutură al gropii era de culoare galbenmaroniu, friabil, conţine şi fragmente milimetrice de cărbune şi pământ ars. Inventar arheologic: o cupă (fragmentară), fragmente din corp care provin de la două vase nedeterminabile ca formă, un turibulum (fragmentar), un opaiț, două piroane și două cuie (fragmentare) din fier și o monedă bronz.

Complexul N157 (mormânt de incineraţie, cu ardere pe loc), Pl. XXVIII, XXXI/2-3.

Amplasament: secțiunea S 006. Orientare: N-S. Dimensiuni: L = 2,34 m; $1=1,46 \mathrm{~m}$; ad =1,06 m. Dimensiuni treaptă: $L_{p}=1,68 \mathrm{~m} ; 1_{p}=1,00 \mathrm{~m}$; ad $=0,62 \mathrm{~m}$. Dimensiuni cameră: $\mathrm{L}_{\text {pext }}=1,68 \mathrm{~m} ; 1_{\text {pext }}$ $=1,02 \mathrm{~m} . \mathrm{L}_{\text {pint }}=1,16 \mathrm{~m} ; 1_{\text {int }}=0,70 \mathrm{~m}$. Dimensiuni cărămizi: laturile lungi $0,40 \times 0,14 \times 0,06 \mathrm{~m}$; laturile scurte $0,30 \times 0,30 \times 0,06 \mathrm{~m}$. Mormânt cu treaptă, partea inferioară era construită sub forma unei camere rectangulare de cărămidă, puternic perturbată de o intervenţie antropică. Groapa arsă; arsură discontinuă de până la $0,03 \mathrm{~m}$. Zona limitrofă prezintă urme de ardere. Fragmentele de os calcinat sunt dispuse în partea inferioară a camerei din cărămidă, compact, fără nicio operaţiune de separare a acestora de resturile rugului (sporadic oase calcinate şi fragmente milimetrice de cărbune). În partea centrală, groapa mormântului era puternic perturbată de o intervenţie antropică. Sedimentul de umplutură al gropii era de culoare galben-maroniu, friabil, conţine fragmente milimetrice de cărbune şi pământ ars. Inventar arheologic: o amforă (un fragment toartă şi unul din corp), o cupă (fragmentară), un capac (fragmentar), un vas nedeterminabil ca formă (fragment corp), un turibulum (fragment buză), un piron din fier (fragmentar), obiecte silex.

Complexul N183 (mormânt de incineraţie, cu ardere pe loc), PI. XXIX, XXX/4.

Amplasament: secțiunea S 006. Orientare: NE-SV. Dimensiuni: $L=1,44 \mathrm{~m} ; 1=0,56 \mathrm{~m}$; ad = 0,34 m. Groapă de formă rectangulară, cu pereții puțin evazaţi, secţiune trapezoidală, partea inferioară a gropii neregulată. Groapa arsă; arsură discontinuă până la 0,03 m grosime. Fragmentele de os calcinat sunt dispuse în partea inferioară a gropii, compact, fără nicio operațiune de separare a acestora de resturile rugului (sporadic oase calcinate şi pigmenţi de cărbune). În partea centrală, groapa mormântului era puternic perturbată de o intervenţie antropică. Sedimentul de umplutură al gropii era de culoare galben-maroniu, friabil, conţine fragmente milimetrice de cărbune şi pământ ars. Mormântul are amenajare exterioară de tipul ,ring” din pietre de râu, cu dimensiuni medii, având un diametru de 2,40 m. Inventar arheologic: o cupă/bol? (fragment), fragmente din corp care provin de la 10 vase nedeterminabile ca formă, un piron (fragmentar) din fier, trei ținte din fier.

\section{CONCLUZII PRELIMINARE}

Cercetările arheologice preventive din perioada 16 martie-20 octombrie 2012, pe traseul autostrăzii A1, Orăştie-Sibiu, lot Orăştie-Sebeş, în raza comunei Şibot, punctul „În Obrej”, km 9+65010+150, au condus la investigarea unei aşezări romane şi a necropolei aferente acesteia. Situl, în ansamblul său, a fost perturbat de intervenții antropice de tot felul de-a lungul vremii (terasări, excavări, construirea DN7 etc.), cât şi a unor evenimente naturale (alunecări de teren, inundaţii etc.). Au fost cercetate peste 300 complexe arheologice, cuprinzând atât complexele cu caracter funerar, cât și cele specifice unei locuiri, databile pe parcursul întregii stăpâniri romane în Dacia.

Cum era de așteptat, cea mai mare parte a sitului este ocupată de zona de locuit, cercetările arheologice punând în evidență limitele de vest, est și sud ale așezării, iar cea de nord, aflată în afara perimetrului autostrăzii, nu putea fi foarte departe deoarece intervenții contemporane au identificat cursul vechi al râului Cugir, la distanțe de la 5 la $10 \mathrm{~m}$ vest de vestigiile arheologice identificate. Așezarea era străbătută, de la est la vest, de un drum, orientat NNE-SSV, care trecea, cel mai 
probabil, la nord de necropolă (traseu similar cu DN7). Din acest drum principal porneau pe direcție perpendiculară cel puțin două străzi secundare care deserveau clădirile aliniate la acestea. Au fost investigate integral sau parțial 17 clădiri, unele dintre acestea fiind amplasate sub terasamentul drumului actual DN7. Clădirile cu plan regulat, orientate similar rețelei de circulație, sunt compartimentate în mai multe încăperi (de la două la nouă, două la cele parțial investigate, dar în general cca cinci sau șase încăperi). Tehnica de construcție este asemănătoare la majoritatea clădirilor, piatră de râu (rar șisturi, calcare și material tegular) legate cu mortar de var-nisip (la locuințe) și cu lut (la dependințe). Nivelurile de funcționare sunt realizate din podea de lut sau, mai rar, din material tegular. Unele încăperi erau prevăzute cu instalații de încălzit, iar clădirile erau acoperite cu țigle și olane. Clădirile au și dependințe, definite cel mai bine prin termenul de curți, care sunt pavate cu pietriș și piatră de râu. Se individualizează două complexe prin caracterul public al funcțiunii, unul reprezentând probabil un spațiu public (forum?/conciliabulum?), iar cel de-al doilea fiind baia aşezării. Pe întreaga suprafaţă a așezării au fost sesizate trei momente cronologice, inegal reprezentate în cadrul complexelor delimitate. Materialul arheologic se află în curs de prelucrare și va aduce nuanțări pentru fiecare dintre aceste faze. Până atunci, pe baza analizei materialului ceramic provenit din cuptoare $^{50}$, complexe care din punct de vedere stratigrafic se plasează în primul orizont cronologic, se poate postula o datare a acestui orizont după cucerirea Daciei - al treilea sfert al secolului al II-lea. Pentru întreaga aşezare se pot oferi date de ordin general, care se încadrează în secolul al II-lea-prima jumătate a secolului al III-lea.

Analiza preliminară a complexelor funerare relevă faptul că dintre cele 210 morminte, 164 sunt morminte de incinerație, pentru 46 nu se poate specifica ritul din cauza stării de conservare precară. Cele 164 sunt morminte cu gropi rectangulare, trapezoidale sau albiate în secţiune, iar dintre acestea 46 sunt morminte de incinerație prevăzute cu treaptă. Dintre aceste din urmă complexe, 28 sunt construite sub forma unei camere rectangulare de cărămidă; 18 sunt gropi arse cu treaptă. Orientarea gropilor mormintelor nu prezintă diferențe majore, constatându-se, cu mici excepții, o preferință pentru axa NE-SV (aproximativ 95\% din cazuri). Se înregistrează, în unele cazuri, ușoare deviaţii spre est sau spre vest de la această axă, însă acestea nu sunt majore. În unele cazuri s-au constatat și amenajări exterioare ale complexelor, și anume trei morminte au amenajare de tipul „ring”, de formă circulară, o amenajare rectangulară de mici dimensiuni pentru unul dintre complexe, 11 morminte amenajate în interiorul unei incinte funerare și șapte morminte amenajate în interiorul unui tumul. Numărul redus de amenajări exterioare este, probabil, datorat stării precare de conservare a întregii necropole. În concluzie, pe baza materialului studiat, putem vorbi, în stadiul actual al cercetării, de o funcționare a necropolei pe parcursul secolului al II-lea şi în prima jumătate a secolului al III-lea.

BIBLIOGRAFIE

Ardevan 1993

Bâltâc, Streinu, Dolea 2017

Bem 2015

Bem et alii 2013

Borș et alii 2013
R. Ardevan, La monnaie d'or dans la Dacie romaine, Studii și cercetări numismatice, X, 1993 (apare 1996), p. 15-26

Adela Bâltâc, Alina Streinu, Alexandra Dolea, The Pottery Kilns at Șibot-În Obrej (Alba County), în Viorica Rusu-Bolindeț, C.-A. Roman, M. Gui, Silvia Mustață, D. Petruț (eds.), Art and craftsmanship, Pottery workshops from the Roman provinces Dacia and Lower Moesia. Proceedings of the National Conference held at Cluj-Napoca in $23^{\text {rd }}-25^{\text {th }}$ of June 2016, Bibliotheca Musei Napocensis, L, 2017 (sub tipar)

C. Bem, Sistemul de fortificare al stațiunii eneolitice de la Pianu de Jos Podei (Alba, România). Intre simbolism și rațiuni defensive, București, 2015

C. Bem, Mădălina Dimache, E. Ene, T. Hila, Fl. Munteanu, V. Opriș, M. Tudoran, B. Voicu, Pianu de Jos, com. Pianu, jud. Alba, Punct: Sibișeni dealul Liștii (autostrada Orăștie-Sibiu, lot 1, sit 11, km 21+500-21+800, CCA, 2013, p. 225-226

Corina Borș, Luciana Irimuș, Vl. Rumega, S. Dobrotă, C. Rișcuța, Un nou sit de tip Basarabi. Raport preliminar asupra cercetărilor arheologice

\footnotetext{
${ }^{50}$ Vezi Bâltâc, Streinu, Dolea 2017.
} 
Borș et alii 2014

Damian et alii 2012

Damian et alii 2013a

Damian et alii 2013b

Dessila-Codarcea 1968

Dumitrașcu, Rațiu, Dolea 2013

IDR III/3

Iordan 1963

Lipovan 1984

Mărghitan 1987

Popa 2002

Popa 2011

RAA

Samson et alii 2014

Simion et alii 2014

Suciu, Moga 1989

Téglás 1902

Tudor 1968 preventive la Tărtăria-Podu Tărtăriei vest (campania 2012), CA, XX, 2013, p. $9-102$

Corina Borș, Luciana Rumega-Irimuș, Vl. Rumega-Irimuș, S. Dobrotă, C. Rișcuța, C. Țuțianu, Un nou sit de la sfârșitul epocii bronzului pe Valea Mureșului Mijlociu. Raport preliminar asupra cercetărilor arheologice preventive de la Aurel Vlaicu-Obreza, CA, XXI, 2014, p. 151-210

P. Damian, I. Bocan, Em. Dumitrașcu, D. Ene, S. Ene, M. Streinu, Autostrada Orăştie-Sibiu, Lot 1 (Orăștie -Sebeș), km 00+000-24+110, jud. Hunedoara, Alba, $C C A, 2012$, p. 280

P. Damian, Corina Borș, C. Cristescu, M. Duca, Em. Dumitrașcu, Fl. Munteanu, N. Stoica, M. Streinu, C. Țuțuianu, Romos, com. Romos, jud. Hunedoara. Punct: Sârba/Valea Vaideilor (Autostrada Orăștie-Sibiu, lot 1, sit 11, km 3+750-4+100), CCA, 2013, p. 228

P. Damian, I. Bocan, D. Vleja, Mădălina Voicu, C. Cristescu, C. Țuțuianu, Pianu de Jos, com. Pianu, jud. Alba, Punct: Lunca Pîrîlui (Autostrada Orăștie-Sibiu, lot 1, sit 11, km 20+550-20+870), CCA, 2013, p. 223-224

Marcela Dessila-Codarcea (redactor coordonator), Harta geologică a României, scara 1:200.000, Comitetul de stat al geologiei, Institutul geologic, 1968

Em. Dumitrașcu, Al. Rațiu, Alexandra Dolea, Cercetări arheologice preventive la Balomiru de Câmp (jud. Alba), CA, XX, 2013, p. 103-140

I.I. Russu, Inscripțiile Daciei Romane, III: Dacia Superior, 3: Zona centrală, București, 1984

I. Iordan, Toponimia Romînească, București, 1963

I. Lipovan, Descoperiri arheologice la Șibot (jud. Alba), AMN, XXI, 1984, p. 459-465

L. Mărghitan, Aspecte ale desfășurării procesului de romanizare în mediul rural al provinciei Dacia, Ziridava, Muzeul județean Arad, XV-XVI, 1987, p. 59-65

D. Popa, Villae, vici, pagi. Aşezări rurale din Dacia romană intracarpatică, Bucureşti, 2002

C. I. Popa, Valea Cugirului din preistorie până în zorii epocii moderne, ClujNapoca, 2011

Repertoriul arheologic al județului Alba, redactori: V. Moga, H. Ciugudean, Alba Iulia, 1995

Andra Samson, M. Vasile, Irina Ene, E. Ene, M. Streinu, Cristina Bodo, G. Băeștean, Situl arheologic medieval de la Șibot-Cânepiște, jud. Alba. Raport preliminar asupra cercetărilor arheologice preventive, CA, XXI, 2014, p. 327-362

Mihaela Simion, D. Vleja, R. Petcu, A. Heroiu, Florela Vasilescu, N. Stoica, Contribuții la cunoașterea epocii romane pe valea Mureșului mijlociu. Cercetări arheologice preventive în situl de la Tărtăria II, com. Sălişte, jud. Alba, CA, XXI, 2014, p. 211-258

Viorica Suciu, V. Moga, O importantă descoperire monetară din secolul I e.n. la Şibot (jud. Alba), Apulum, XXV, 1989, p. 161-169

Hunyadvármegye. Földjének története az öskortól a Honfoglalásig, G. Kuun Géza, Z. Torma, G. Téglás, Budapesta, 1902

D. Tudor, Oraşe, tîrguri şi sate în Dacia romană, Bucureşti, 1968

\section{LISTA ILUSTRAȚIEI}

PI. I. 1. Localitatea Şibot (jud. Alba), vedere satelitară (@GoogleEarth); 2. Localizarea punctelor cu vestigii arheologice din epoca romană pe raza comunei Șibot, vedere satelitară (OGoogleEarth).

PI. II. 1. Localizarea punctului „În Obrej”, ortofotoplan (2009); 2. Plan general cu secțiunile efectuate în etapa de evaluare (octombrie-decembrie 2011) în punctul „În Obrej”.

PI. III. Situl arheologic „În Obrej”, vedere aeriană.

PI. IV. Intervenții antropice anterioare anului 2011: 1. Folosirea zonei ca cimitir de animale; 2. Regularizarea cursului Cugir și excavarea pantei nordice a dealului „În Țelini”; 3. Introducerea conductei de gaze. 
Pl. V. Punctul „În Obrej” la începutul anului 2012: 1. Zona necropolei, vedere dinspre vest (dinspre așezare); 2. Panta nordică a dealului „În Țelini”, vedere dinspre nord-est; 3. Zona așezării, vedere dinspre est (dinspre necropolă).

PI. VI. Delimitarea sitului „În Obrej” pe ortofotoplan în culoarul autostrăzii.

PI. VII. Planul general al secțiunilor efectuate în zona sitului delimitat.

PI. VIII. Aspecte de lucru: 1. Așezare; 2. Necropolă.

PI. IX. Situl arheologic Șibot, punctul ,În Obrej” (Virgil Apostol): 1. Plan general; 2. Detaliu așezare

PI. X. Așezare, suprafața A4, profil vest (secțiune longitudinală pe lățimea autostrăzii).

PI. XI. Necropolă, suprafața S 004, profilul de est.

PI. XII. Așezare, sud DN7, Complexul A009 („Edificiul nr. 1”), plan general.

Pl. XIII. Așezare, nord DN7, Complexul A025 („Clădirea nr. 5”), plan general.

PI. XIV. Așezare, nord DN7, Complexul A027 („Clădirea nr. 7”), plan general.

PI. XV. 1. Așezare, nord DN7: 1. Complexul A007 („Edificiul nr. 3”), vedere dinspre sud-est; 2. Complexul A024 („Clădirea nr. 4”), vedere dinspre vest.

PI. XVI. Așezare, nord DN7, complexul A025 („Strada nr. 1”): 1. Faza a II-a, vedere dinspre sud; 2. Cele două faze, vedere dinspre nord.

PI. XVII. Așezare, nord DN7, complexul A041 (drum): 1. Vedere dinspre est; 2. Vedere dinspre vest.

PI. XVIII. Așezare, nord DN7, complexul A038 (cuptor) 1. Plan și profil; 2. Imagine, vedere dinspre nord.

PI. XIX. Situl arheologic Șibot, punctul „În Obrej” (Virgil Apostol): Necropola, pan general.

PI. XX. Necropolă, complexul N007 (plan, profil și inventar).

PI. XXI. Necropolă, complexul N021 (plan, profil și inventar).

PI. XXII. Necropolă, complexul N041(plan, profil și inventar).

PI. XXIII. Necropolă, complexul N086c (plan, profil și inventar).

PI. XXIV. Necropolă, complexul N133 (plan, profil și inventar).

PI. XXV. Necropolă, complexul N135 (plan, profil și inventar).

PI. XXVI. Necropolă, complexul N141 (plan, profil și inventar).

PI. XXVII. Necropolă, complexul N153 (plan, profil și inventar).

Pl. XXVIII. Necropolă, complexul N157 (plan, profil și inventar)

PI. XXIX. Necropolă, complexul N183 (plan, profil și inventar).

PI. XXX. Necropolă, imagini: 1. Complexul N021; 2. Complexul N096c; 3. Complexul N096c (profil); 4. Complexul N183.

PI. XXXI. Necropolă, imagini: 1. Complexul N135; 2. Complexul N157; 3. Complexul N157 (profil); 4. Complexul N133.

PI. XXXII. Așezare: ceramică (imagini).

PI. XXXIII. Așezare: ceramică, opaițe și figurine din teracotă (imagini).

PI. XXXIV. Așezare: oale (desene).

PI. XXXV. Așezare: farfurii, platouri, castroane. (desene).

PI. XXXVI. Așezare: cupe (desene).

PI. XXXVII. Așezare: capace (desene).

Pl. XXXVIII. Așezare: mortarium și turibulum (desene)

PI. XXXIX. Așezare: obiecte din bronz, fier: 1. Imagini; 2. Desene.

PI. XL. Materiale de construcție: 1. Așezare (imagini); 2. Necropolă (desene).

\section{LIST OF ILLUSTRATION}

Pl. I. 1. The Şibot commune (Alba County), satellite image (C GoogleEarth); 2. Location of the archaeological sites with vestiges remains from the Roman times in the territory of Şibot commune, satellite image (C) GoogleEarth).

PI. II. 1. Location of the site Şibot-În Obrej, orthophoto layout (2009); 2. General Plan of the trenches made in the survey stage (October-December 2011) in the site In Obrej.

PI. III. Archaeological site Şibot-În Obrej, aerial view.

Pl. IV. Human interventions before 2011: 1. Using of the area as a cemetery for animals; 2. Regularization of the Cugir River and excavation on the northern slope of the hill "În Țelini"; 3. Insertion of the gas pipeline.

PI. V. The site Şibot-În Obrej in early 2012: 1. The necropolis area, view from the west (from the settlement); 2. Northern slope of the hill "În Țelini", view from the northeast; 3. Settlement area, view from the east (from the necropolis).

PI. VI. The delimitation of the site Şibot-În Obrej, within the highway's outline (orthophoto).

PI. VII. The general outline of trenches made in the area of the delineated site.

PI. VIII. Excavation aspects: 1. Settlement; 2. Necropolis. 
PI. IX. Archaeological site Şibot-În Obrej (Virgil Apostol): 1. General plan; 2. Settlement (detail)

Pl. X. Settlement, A4 surface, western cross-section (longitudinal section made over the highway's width).

PI. XI. Necropolis, S 004 surface, eastern cross-section.

PI. XII. Settlement, south of National Route 7, A009 Complex ("Edifice no. 1"), general plan.

PI. XIII. Settlement, north of National Route 7, A025 Complex ("Building no. 5"), general plan.

PI. XIV. Settlement, north of National Route 7, A027 Complex (“Building no. 7”), general plan.

PI. XV. 1. Settlement, north of National Route 7, A007 Complex ("Building no. 3"), view from south-east; 2. Settlement, north of National Route 7, A024 Complex ("Building no. 4"), view from the west.

PI. XVI. Settlement, north of National Route 7, A025 Complex ("Street no. 1"): 1. Phase II, view from the south; 2. Phases I and II, view from the north.

PI. XVII. Settlement, north of National Route 7, complex A041 (road): 1. View from the east; 2. View from the west.

PI. XVIII. Settlement, north of National Route 7, complex A38 (kiln) 1. Plan and cross-section; 2. Photo view from the north.

PI. XIX. Situl arheologic Șibot-În Obrej (Virgil Apostol): Necropola, pan general.

PI. XX. Necropolis, complex N007 (plan, cross-section and inventory).

PI. XXI. Necropolis, complex N021 (plan, cross-section and inventory).

PI. XXII. Necropolis, complex N041 (plan, cross-section and inventory).

PI. XXIII. Necropolis, complex N086c (plan, cross-section and inventory).

PI. XXIV. Necropolis, complex N133 (plan, cross-section and inventory).

Pl. XXV. Necropolis, complex N135 (plan, cross-section and inventory).

PI. XXVI. Necropolis, complex N141 (plan, cross-section and inventory).

PI. XXVII. Necropolis, complex N153 (plan, cross-section and inventory).

PI. XXVIII. Necropolis, complex N157 (plan, cross-section and inventory).

PI. XXIX. Necropolis, complex N183 (plan, cross-section and inventory).

PI. XXX. Necropolis, photo: 1. Complex N021; 2. Complex N096c; 3. Complex N096c (cross-section) 4. Complex N183.

PI. XXXI. Necropolis, photo: 1. Complex N135; 2. Complex N157; 3. Complex N157 (cross-section) 4. Complex N133.

PI. XXXII. Settlement: pottery from the settlement (photos).

PI. XXXIII. Settlement: pottery, clay lamps and terracotta figurines (photos).

PI. XXXIV. Settlement: coarse ware vessels (drawings).

PI. XXXV. Settlement: plates, cooking pans and bowls (drawings).

PI. XXXVI. Settlement: cups (drawings).

PI. XXXVII. Settlement: lids (drawings).

PI. XXXVIII. Settlement: mortarium and turibulum (drawings).

Pl. XXXIX. Settlement: bronze and iron objects: 1. Photos; 2. Drawings.

PI. XL. Construction material: 1. Settlement (photos); 2. Necropolis (drawings).

Desen piese/Objects' drawings: Georgiana Ducman, Alina Streinu, Alexandra Dolea.

Foto piese/Objects' photos: George Nica, Corina Nicolae.

Restaurare piese/Objects' restauration: Ileana Zahariade (ceramică/pottery), Sergiu Popescu (metale/metals).

Adela BÂltâc, Paul Damian, Eugen Paraschiv-Grigore, Corina Nicolae, Bogdan Voicu, Muzeul Naţional de Istorie a României, adela.baltac@gmail.com; pauldamian@gmail.com; para_eugen@yahoo.com; bogdan_liviu_voicu@hotmail.com

VIRGIL APOSTOL,

Institutul de Arheologie „Vasile Pârvan”, București, apostol_virgil@yahoo.com

ALINA STREINU,

Muzeul Municipiului București, musatalina@yahoo.com

ALEXANDRA DOLEA,

Österreichisches Archäologisches Institut, alexandra.dolea@ oeai.at IOANA PARASCHIV-GRIGORE,

Compania Națională de Administrare a Infrastructurii Rutiere, ioana.gri@gmail.com 

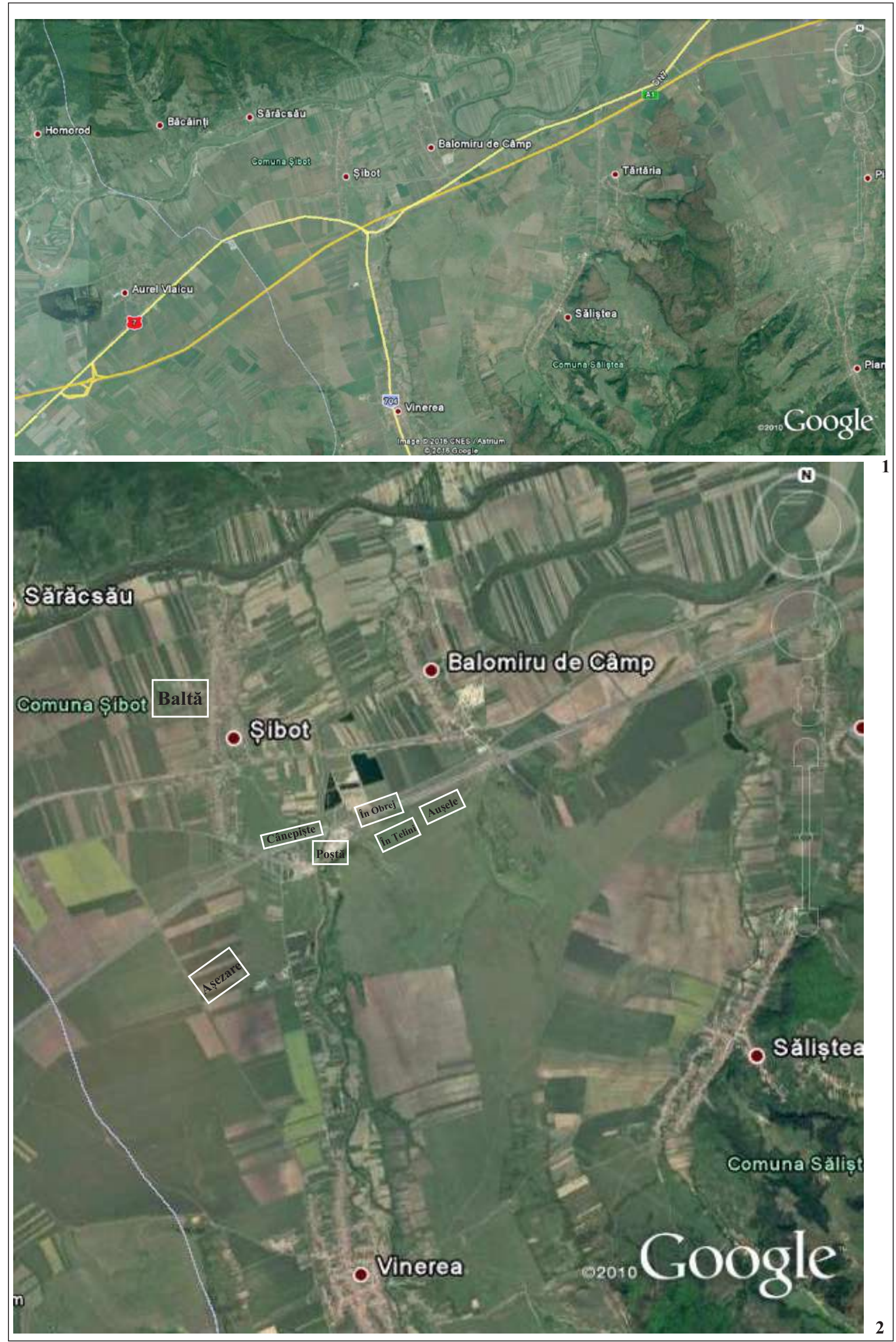

Pl. I 

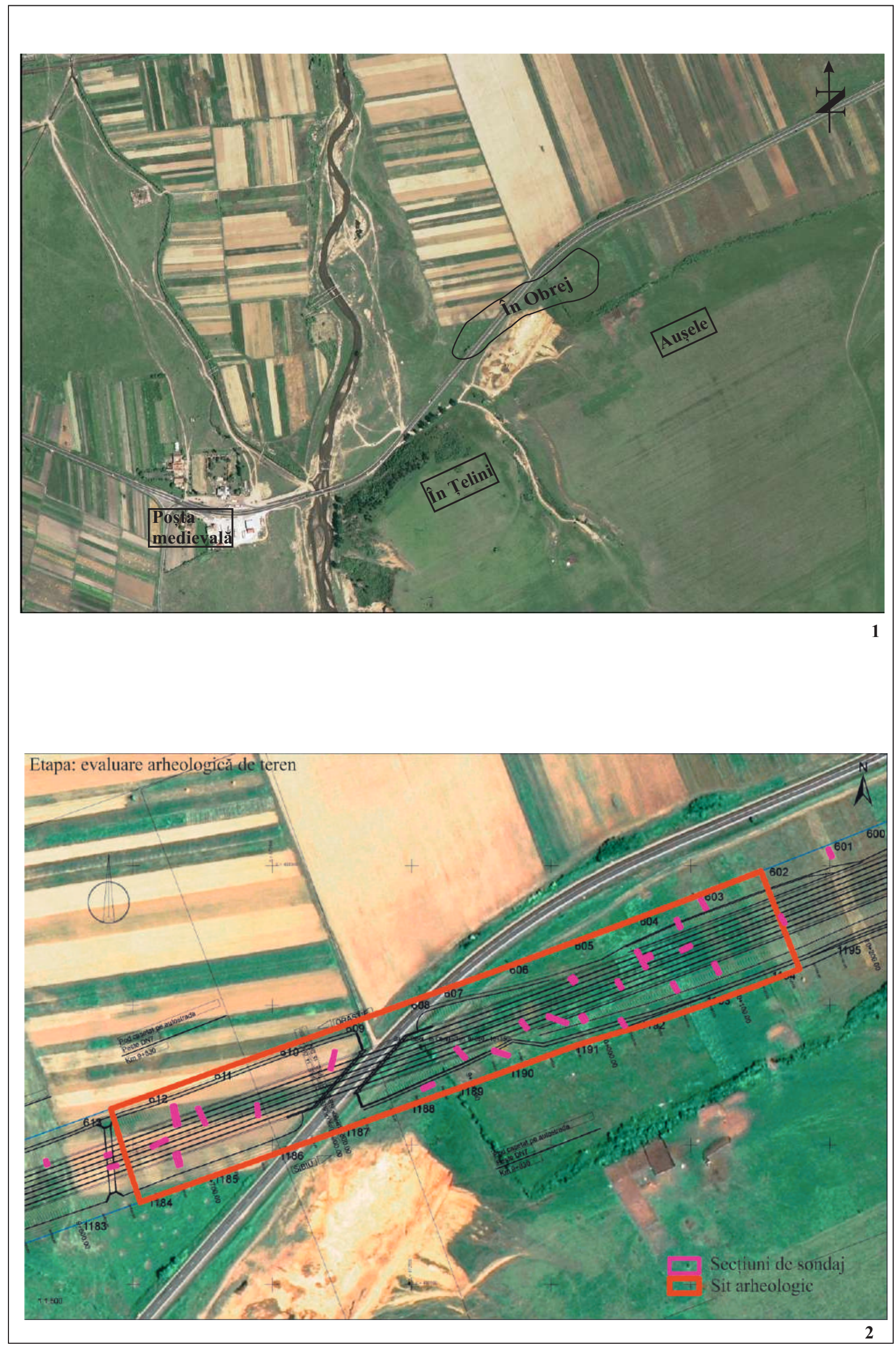

PI. II 


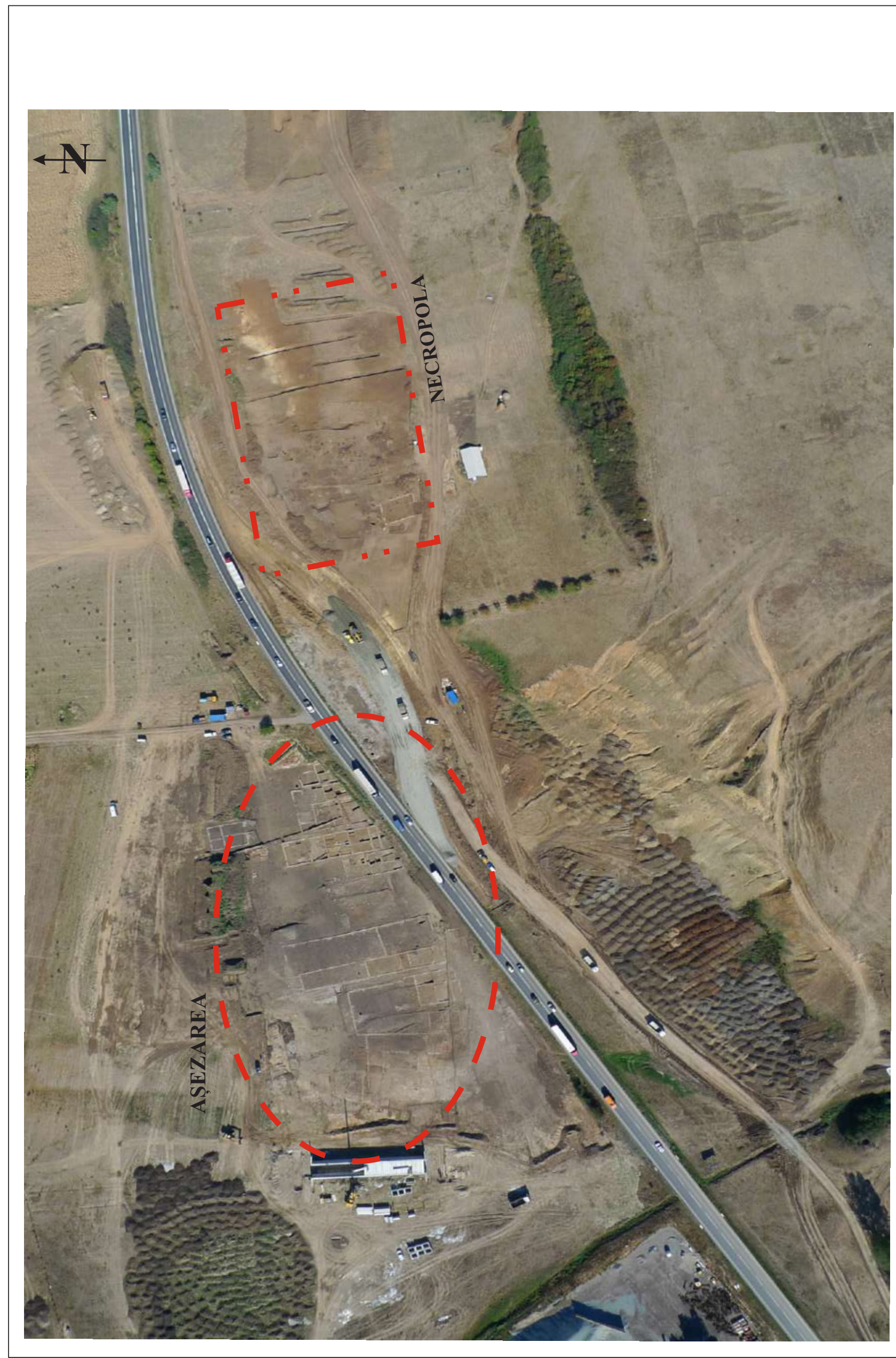

$\underset{B}{\Xi}$ 


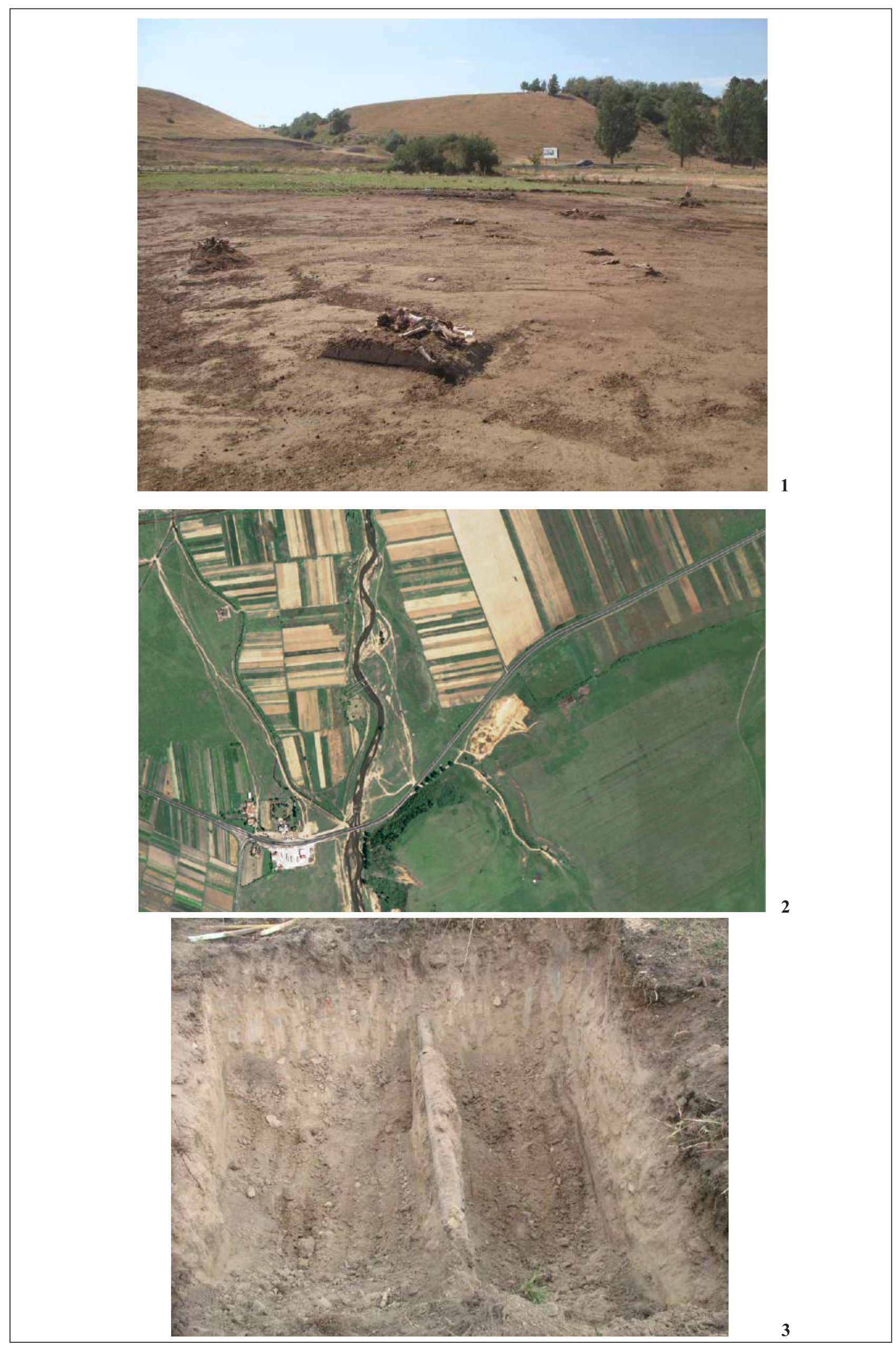

PI. IV 


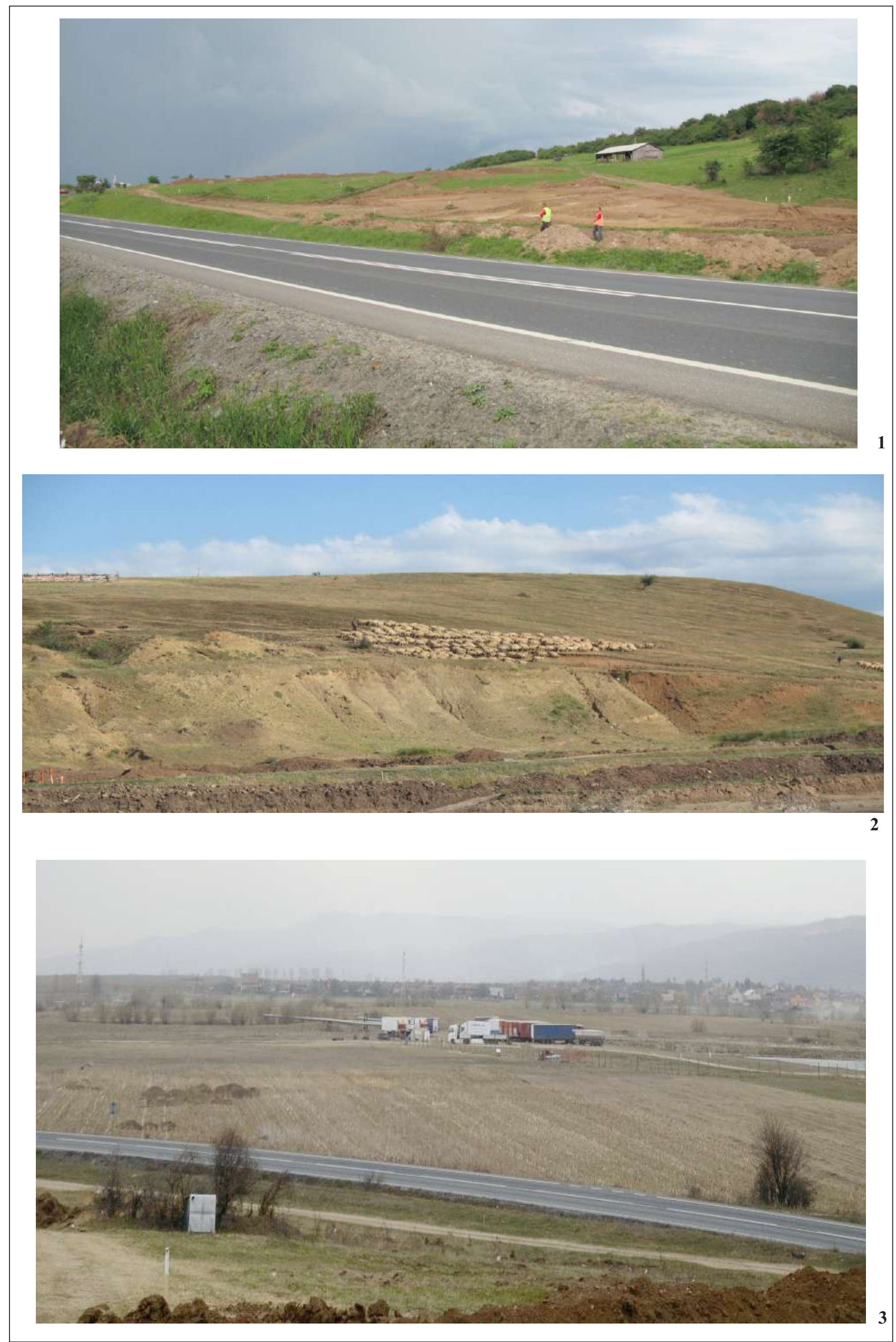

PI. V 


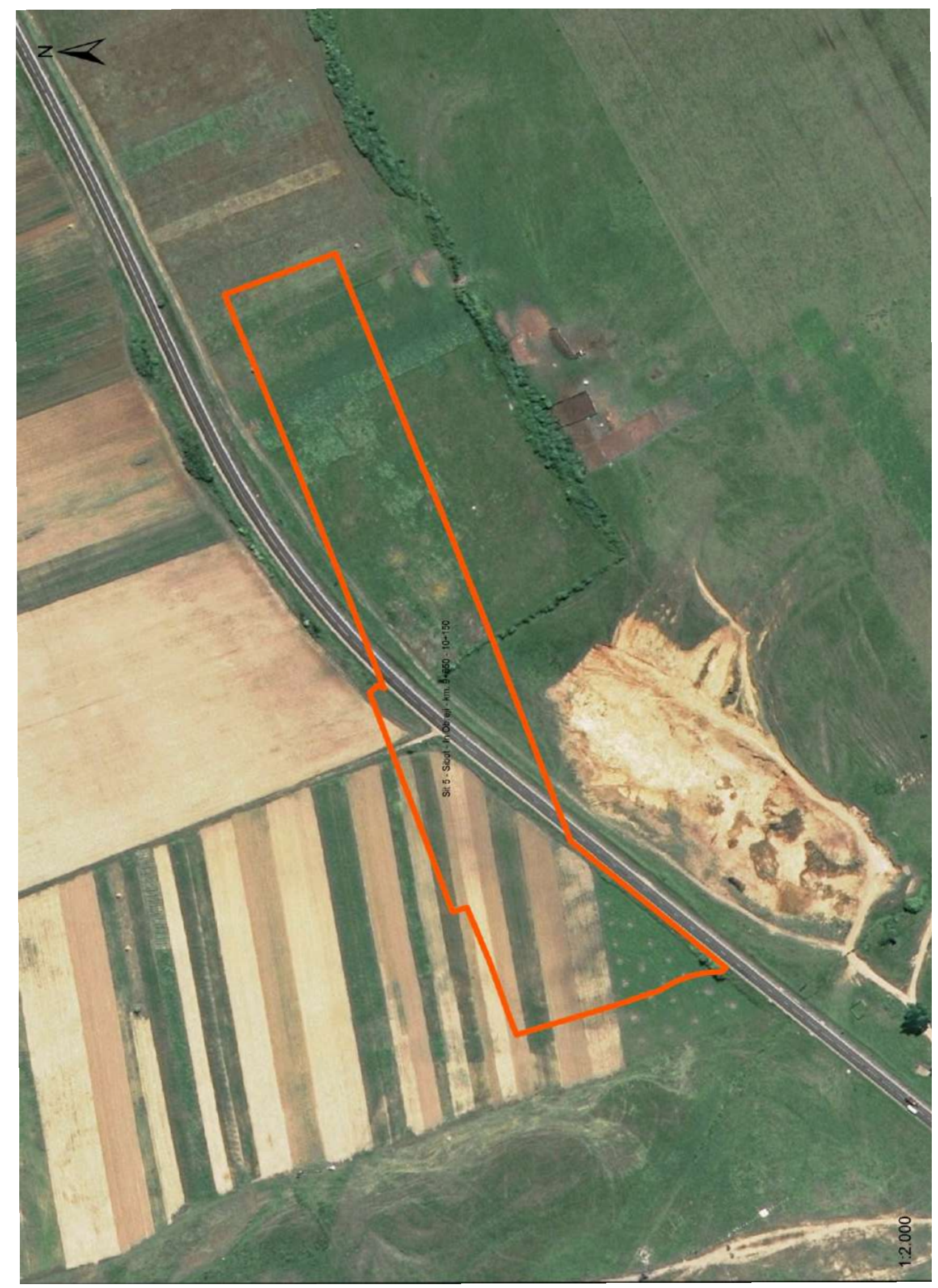

$\frac{5}{2}$ 


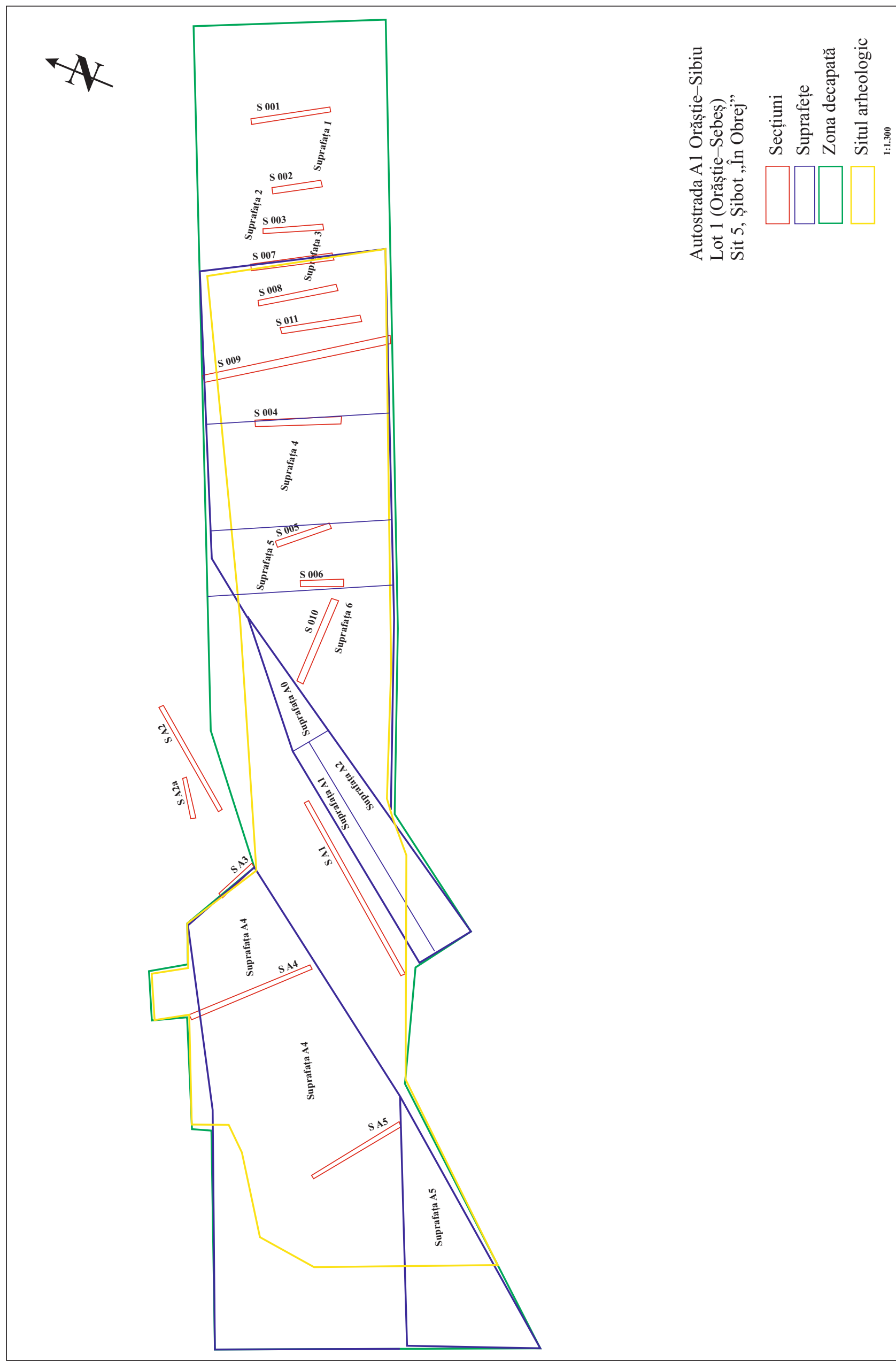

$\stackrel{i}{i}$ 


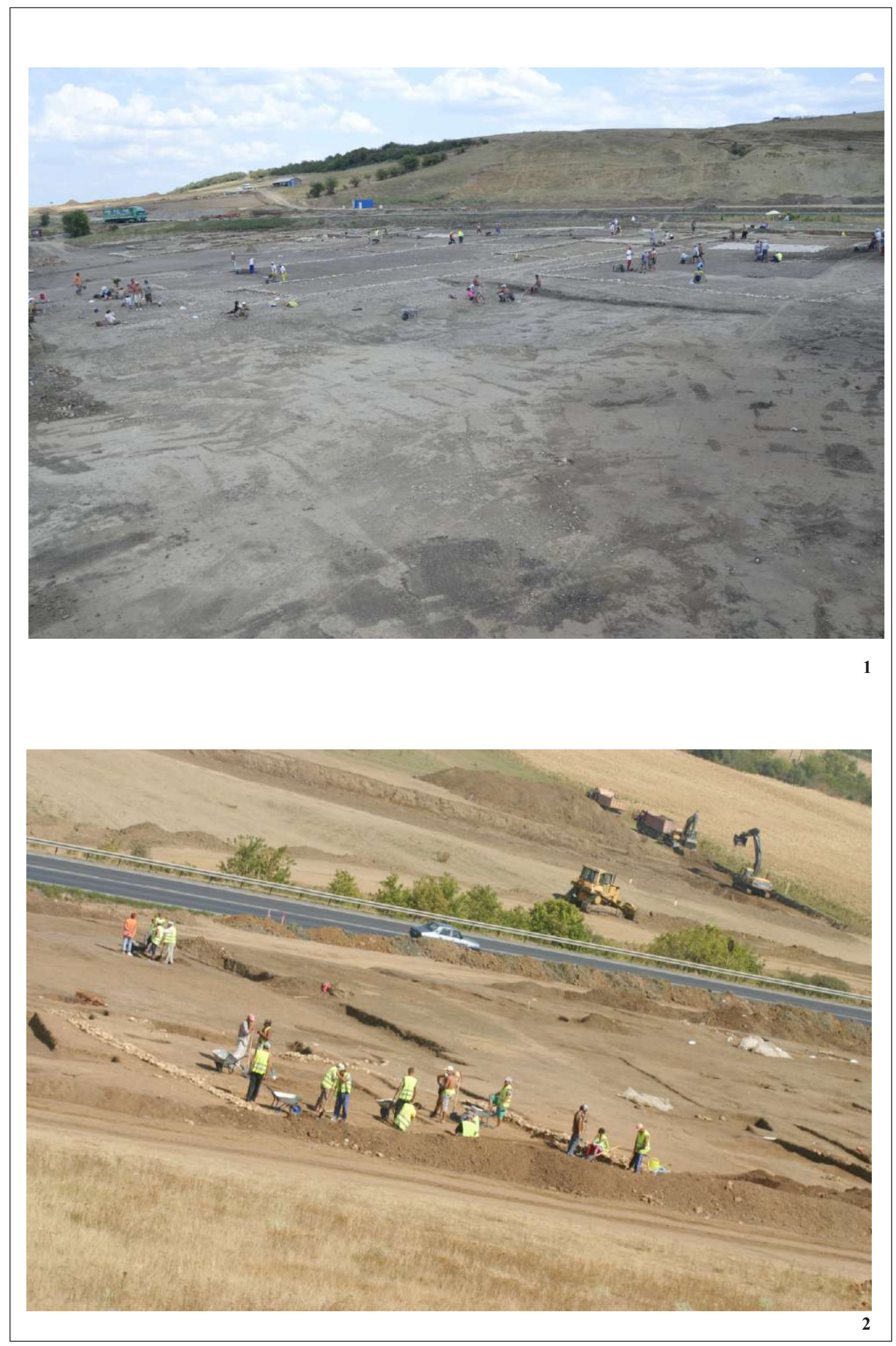

PI. VIII 


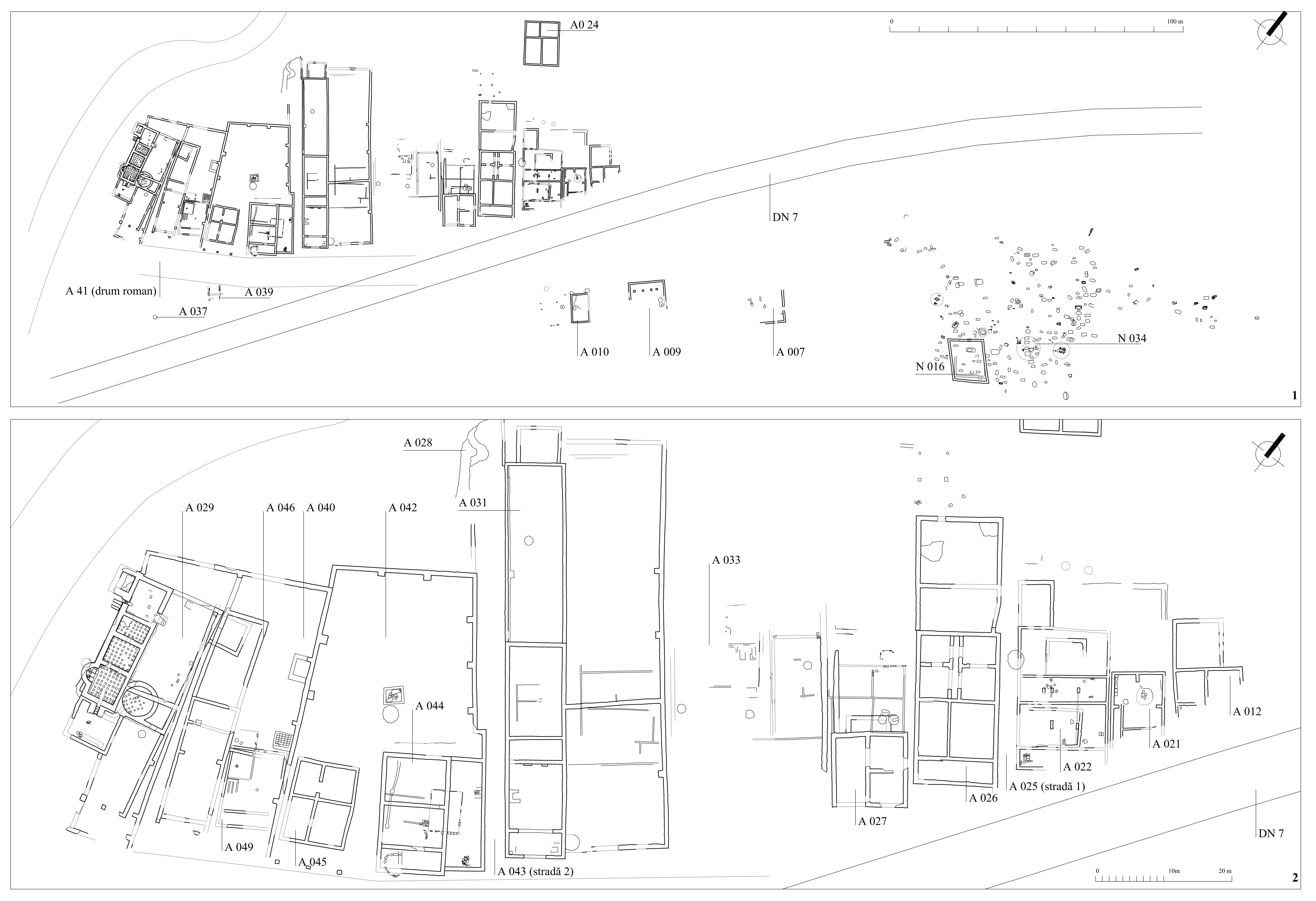




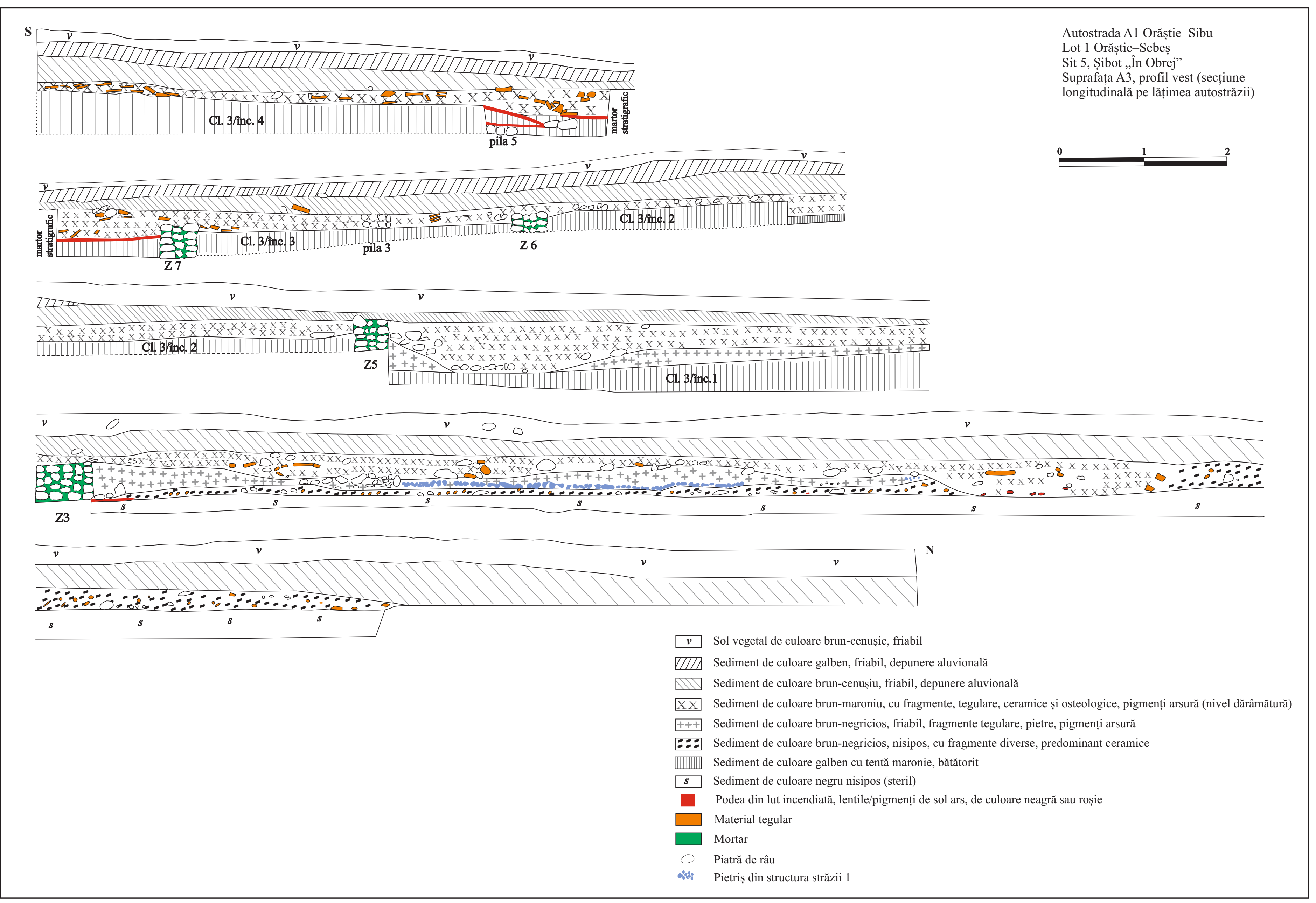



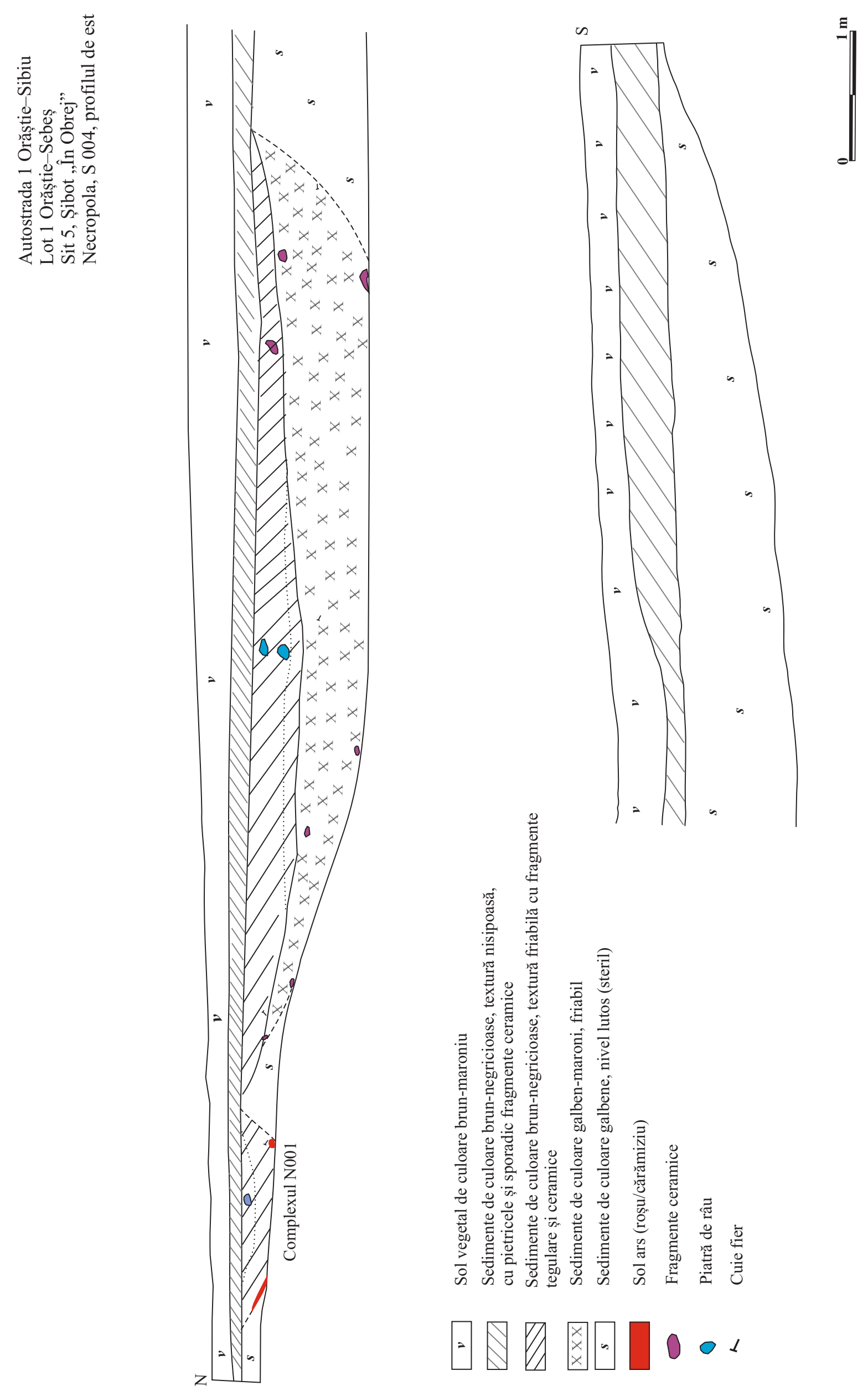

a 


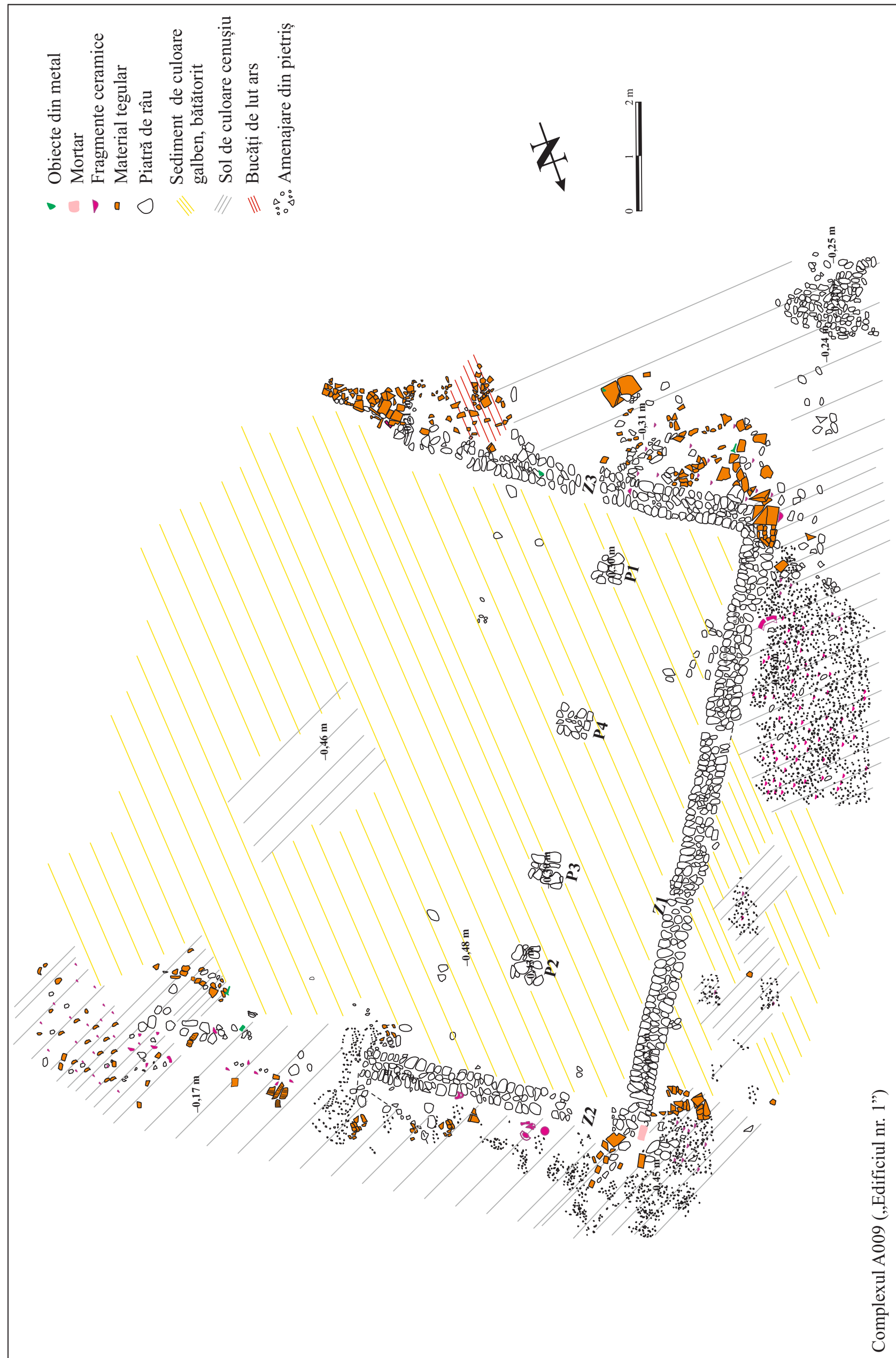




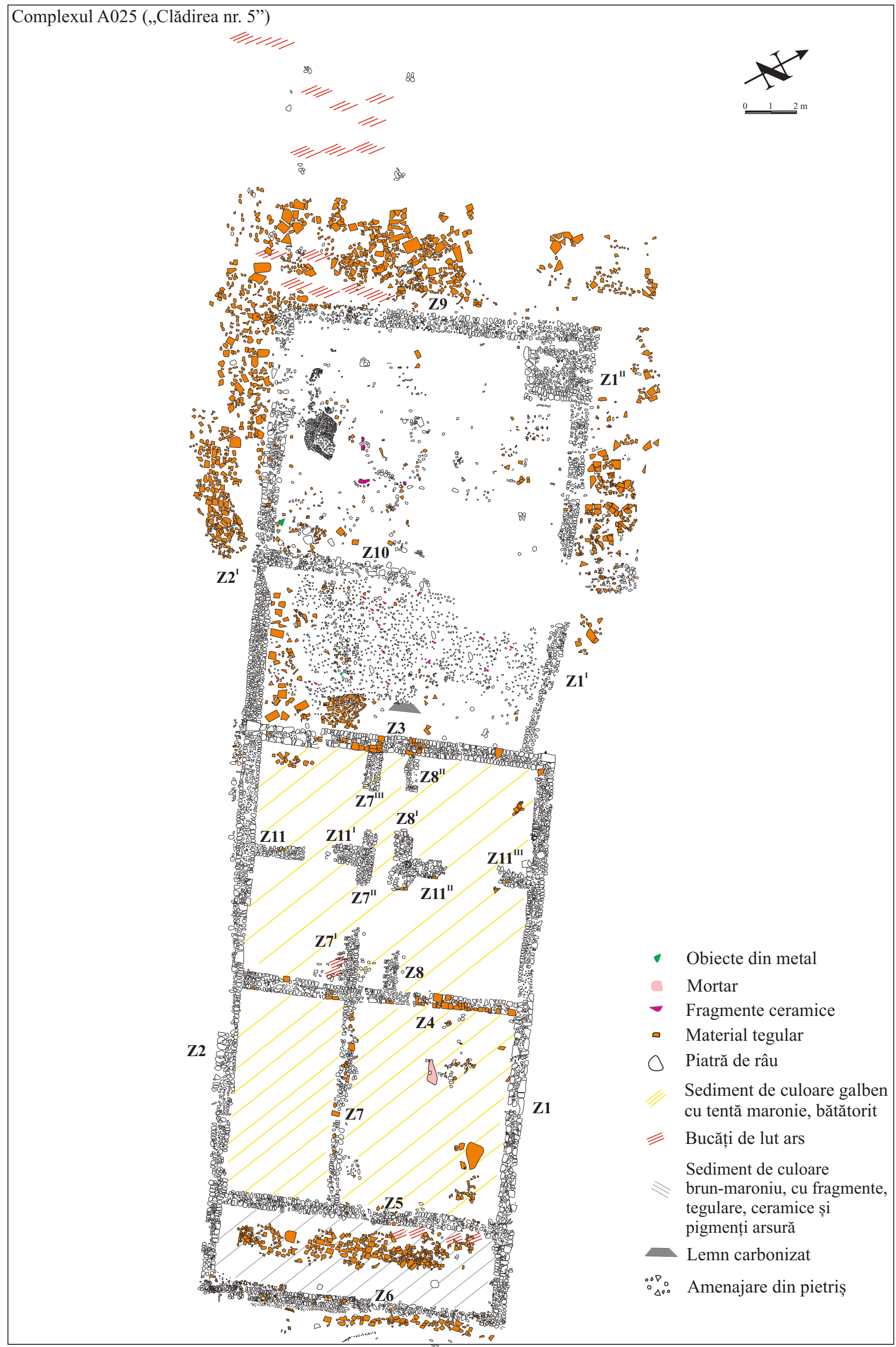

PI. XIII 


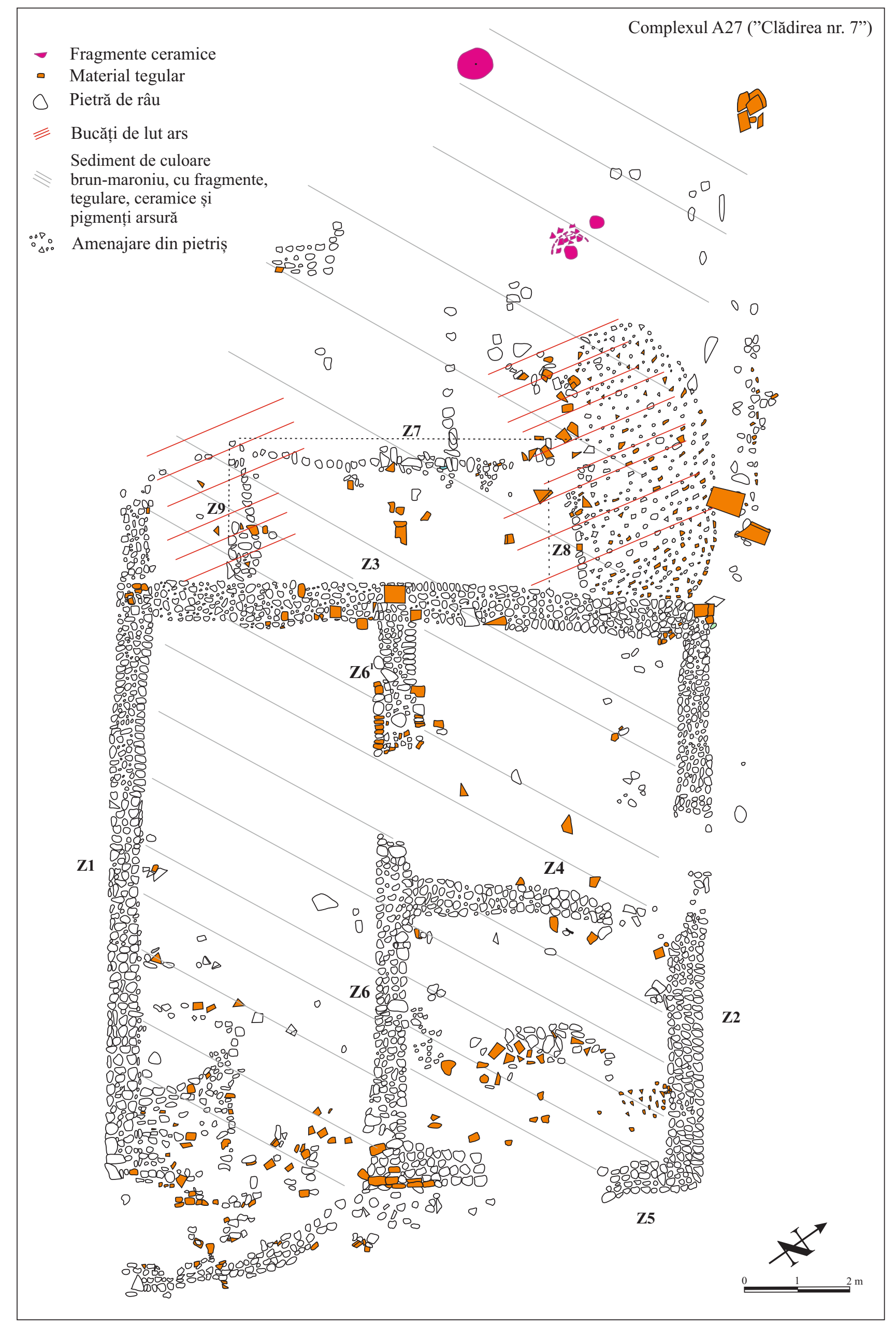

PI. XIV 

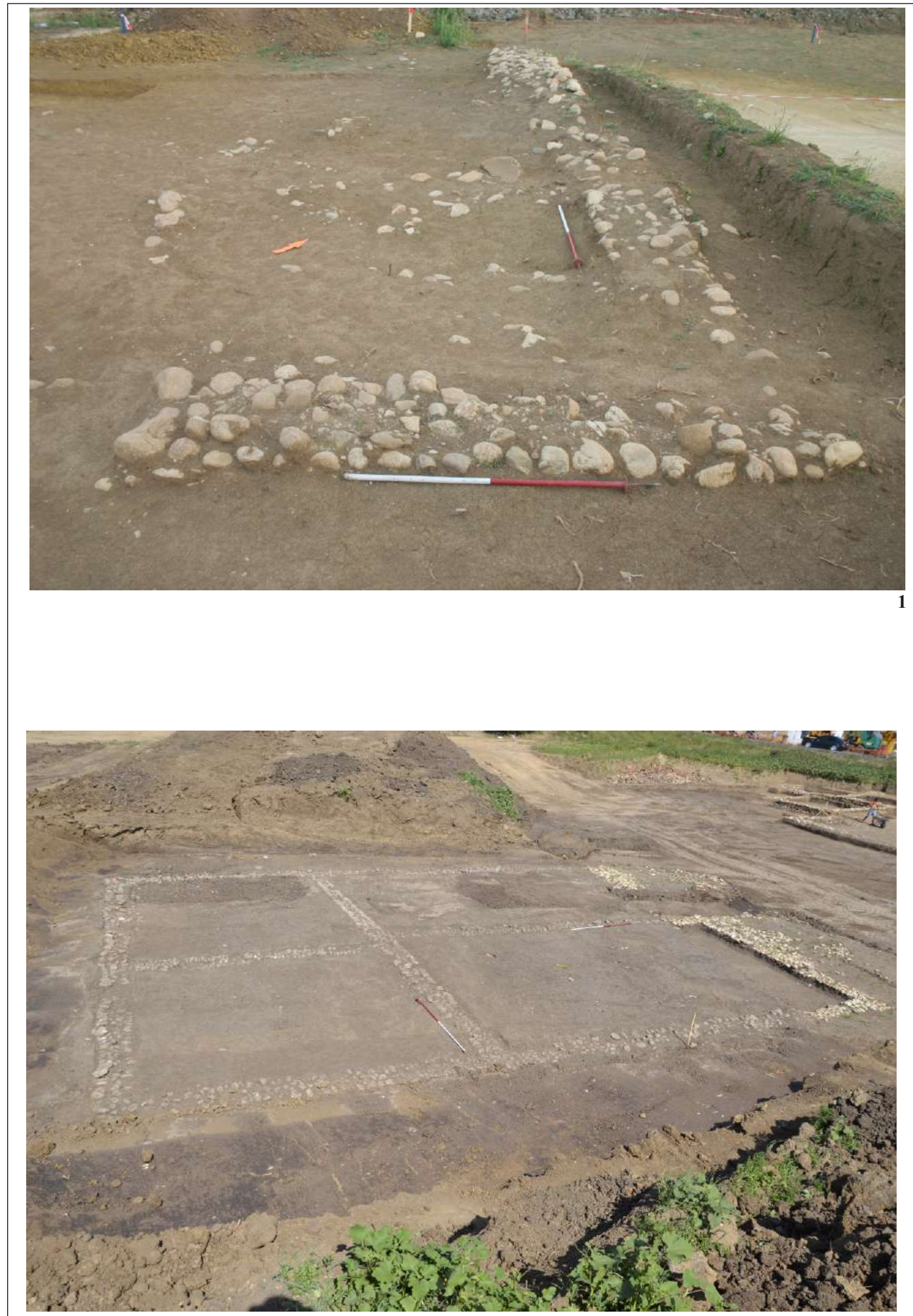


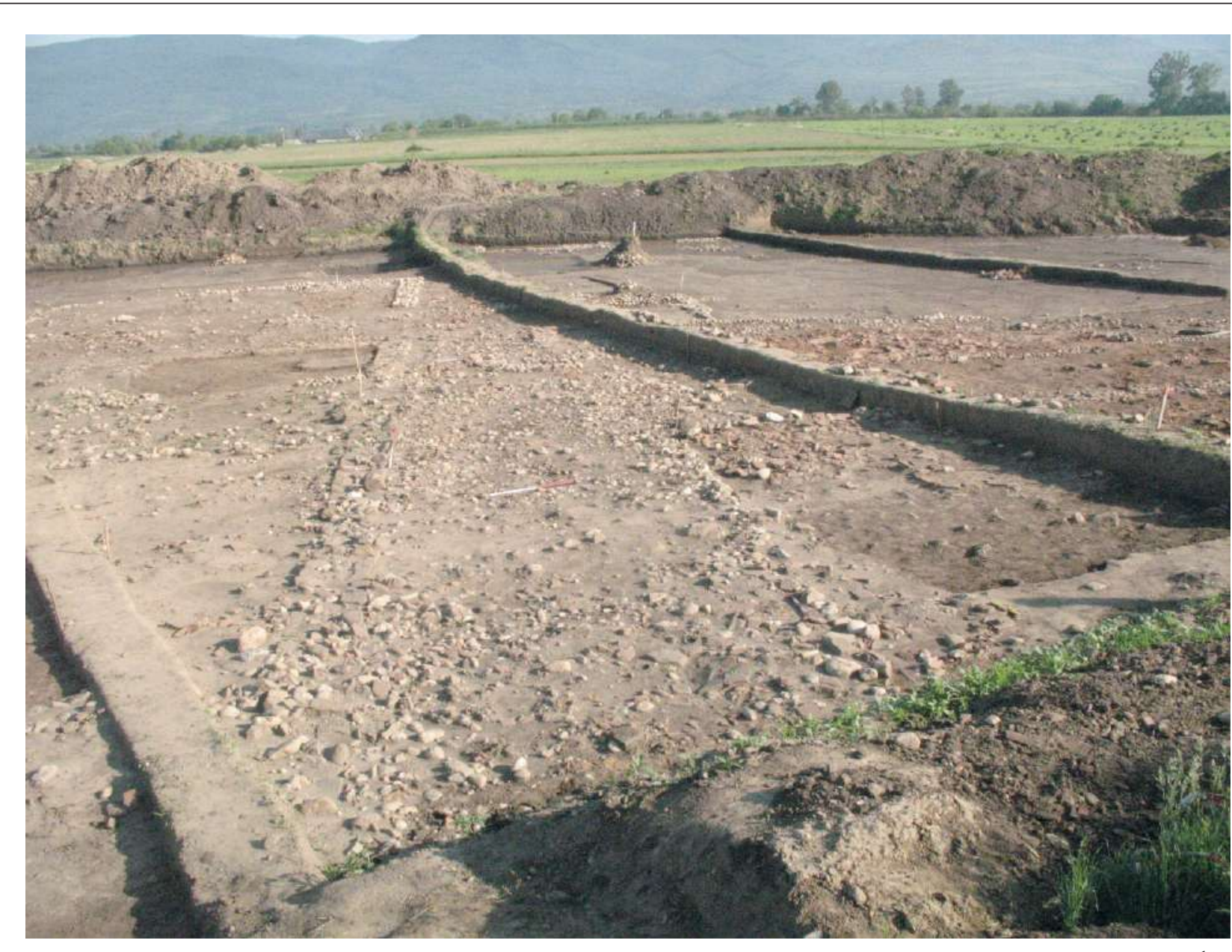

1

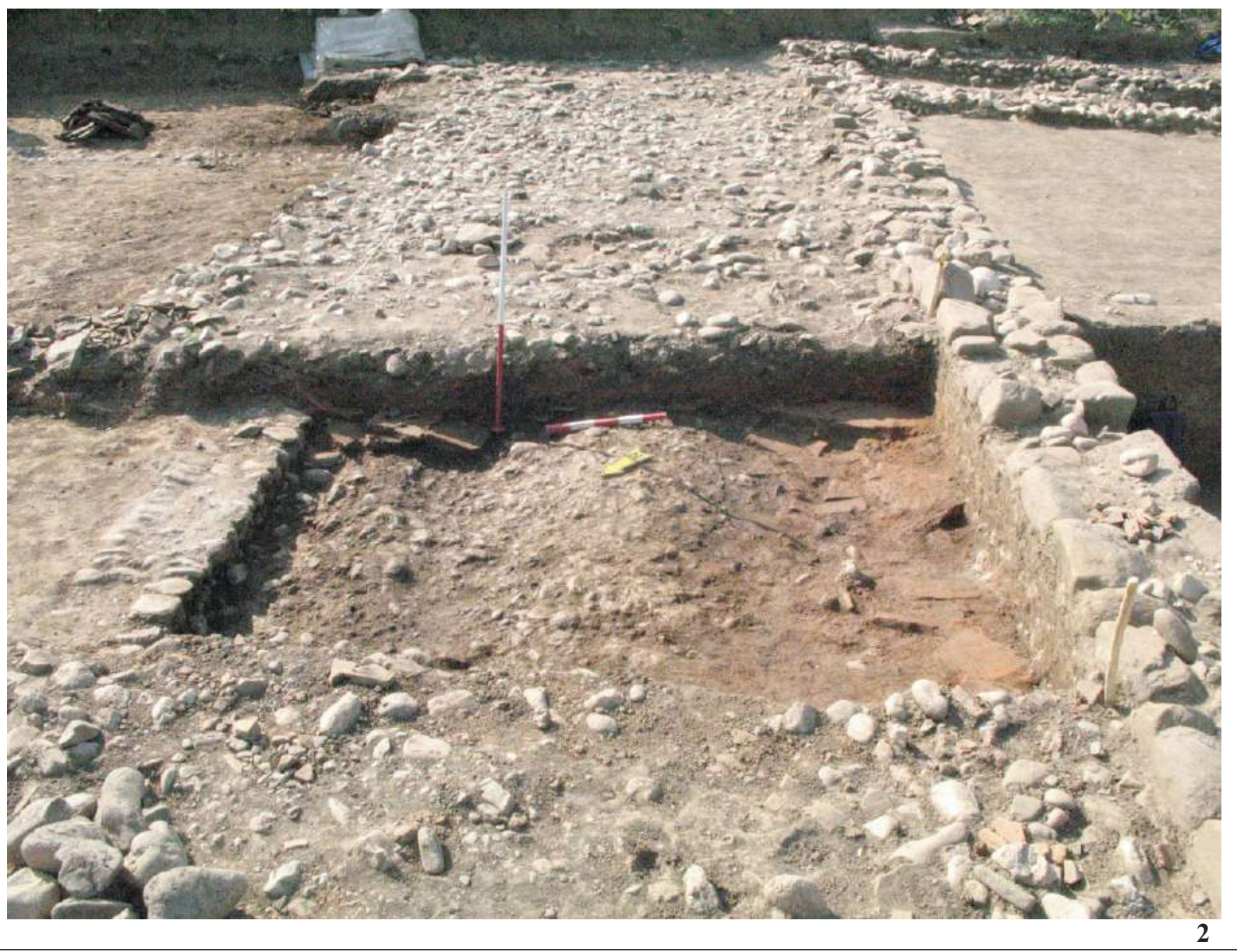



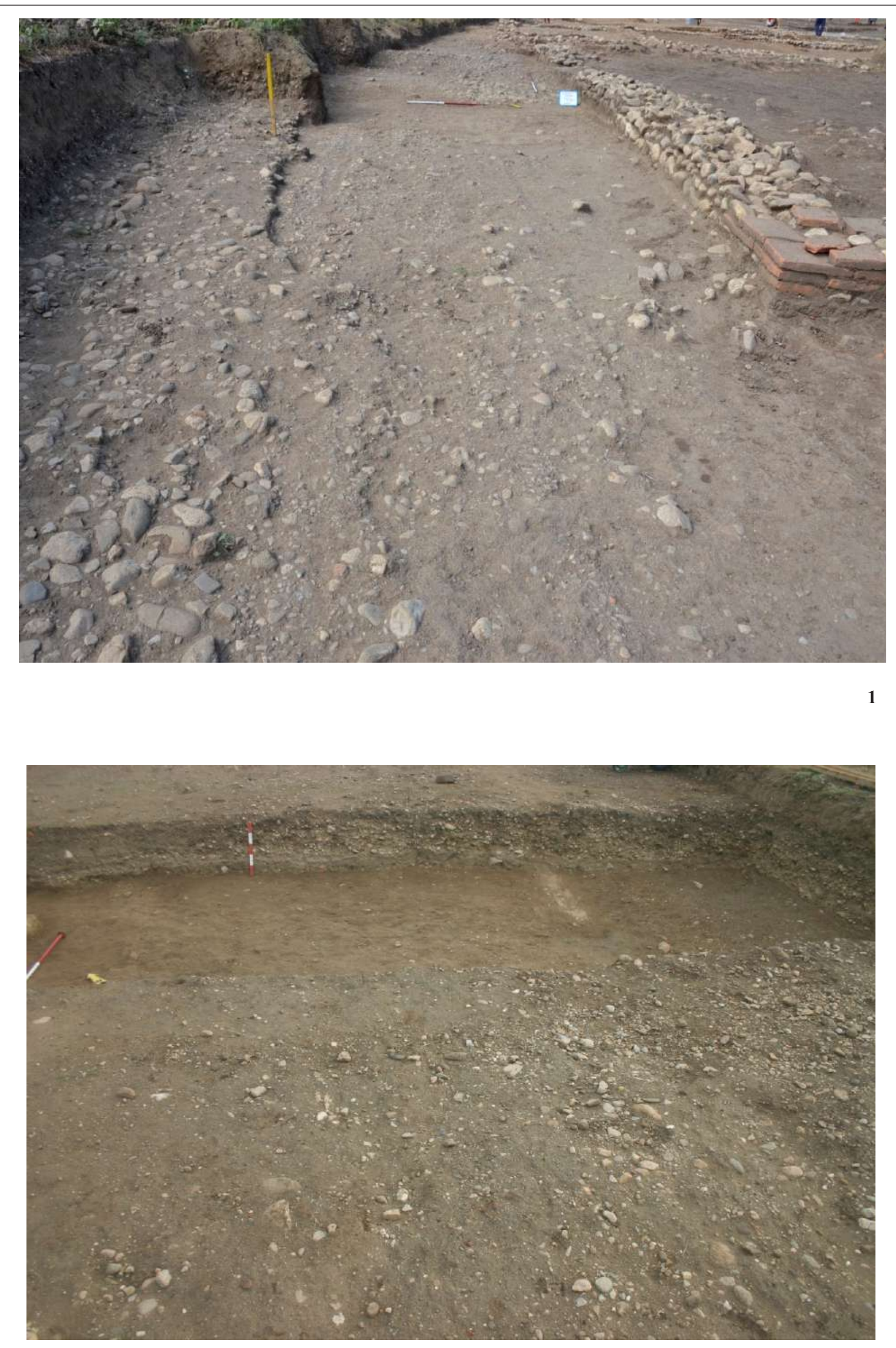


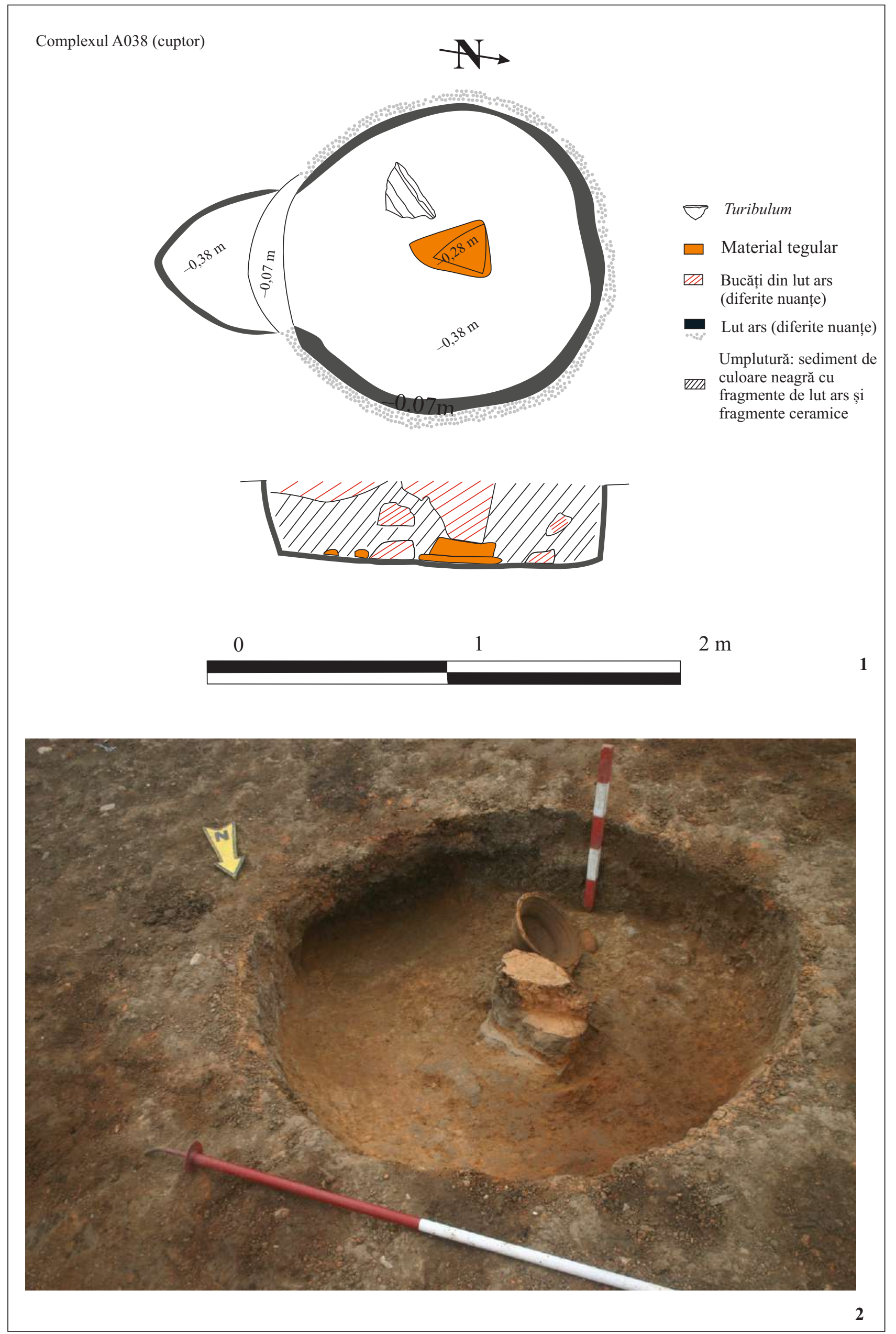

Pl. XVIII 


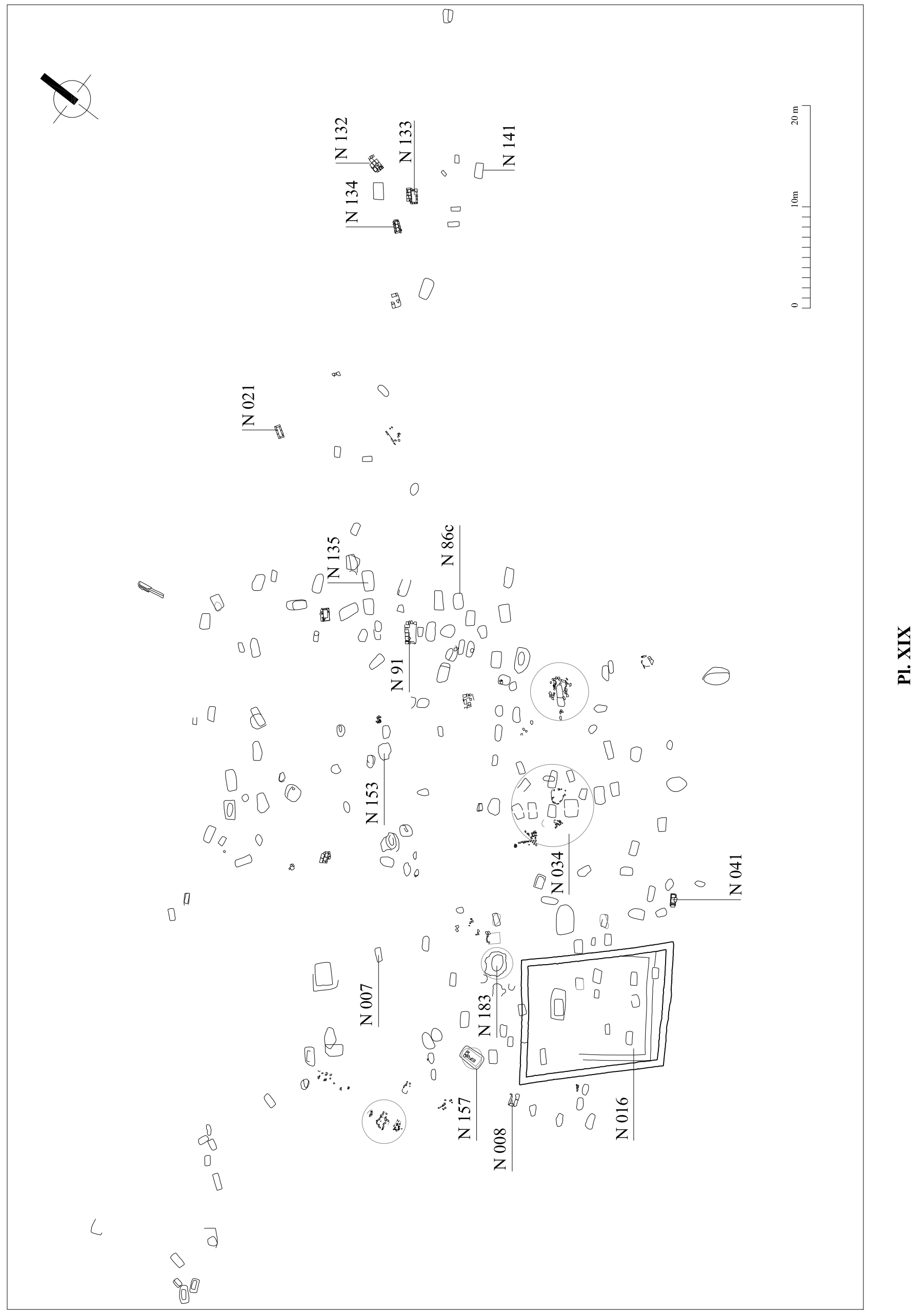


Complexul N007
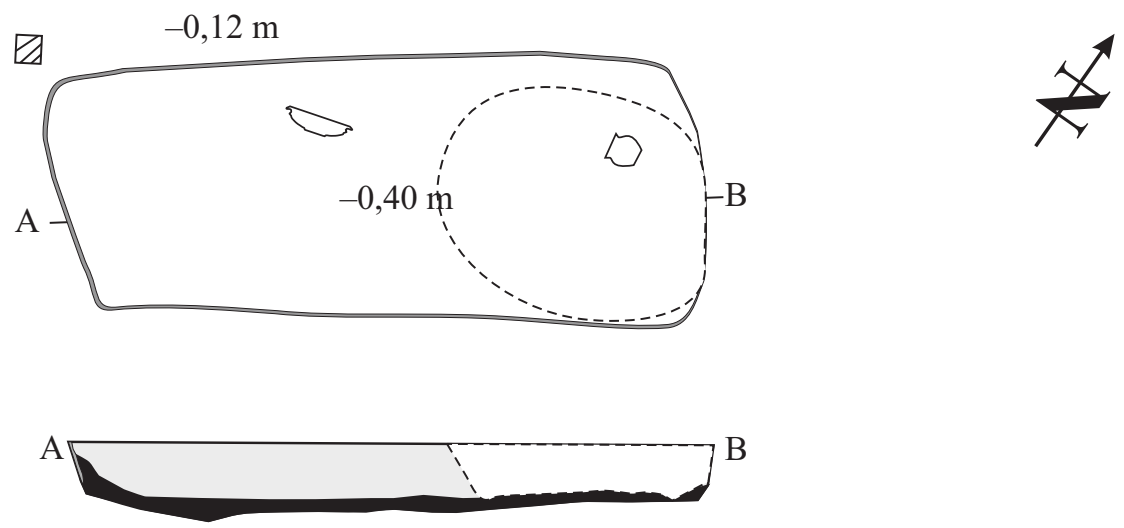

0

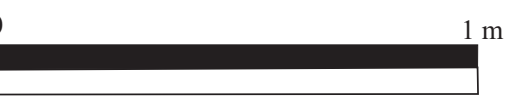

Conturul gropii mormântului

Solum ars (roșu/cărămiziu)

- Nivel de reziduuri ale cremaţiei

Sedimentul (galben-maroniu) de umplutură al gropii mormântului

(-) Conturul gropii de intervenţie antropică
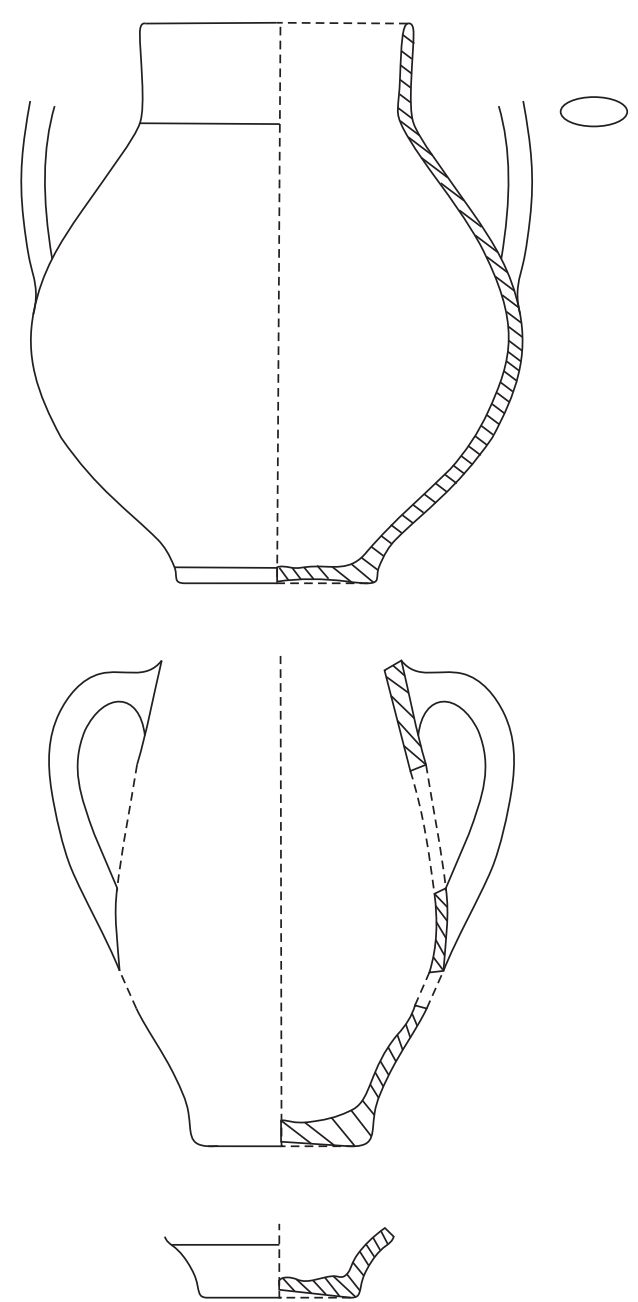

Cupă

$\smile$ Platou

$\bigotimes \quad$ Vas nedeterminabil ca formă
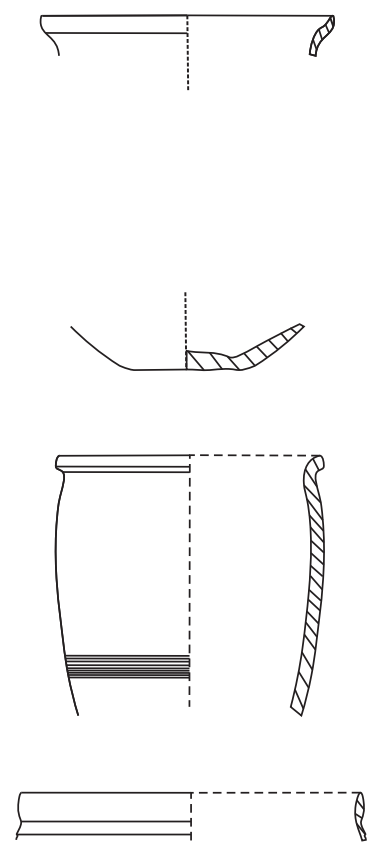

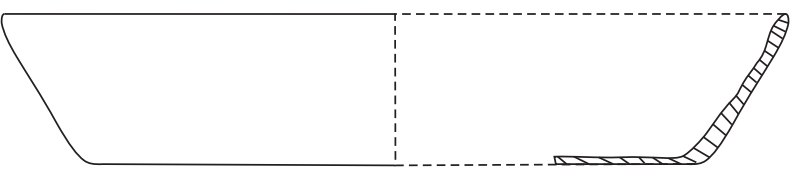

늘

Pl. XX 


\section{Complexul N021}

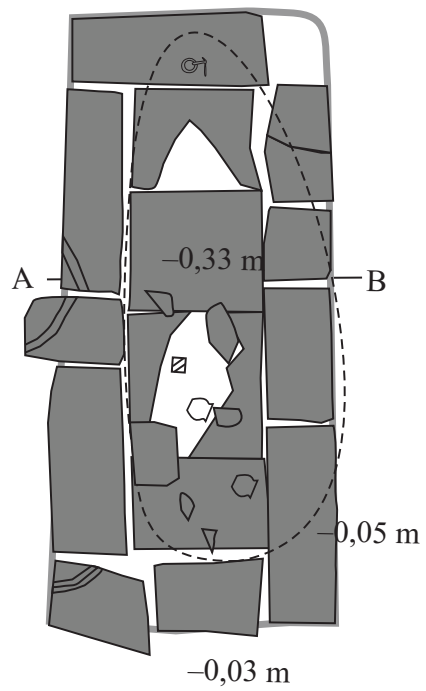

A

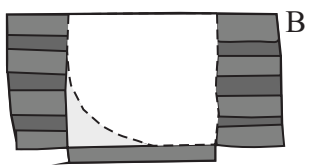

0

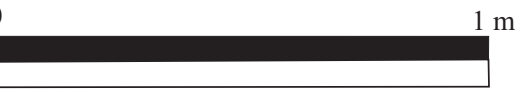

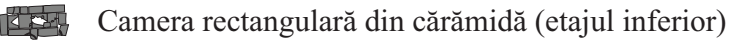

Conturul gropii mormântului (sol ars - roșu/cărămiziu )

Sedimentul (galben-maroniu) de umplutură al gropii mormântului

Conturul gropii de intervenţie antropică

Cărămidă

$\square$ Cupă

$\bigotimes \quad$ Vas nedeterminabil ca formă

(a) Obiect din bronz
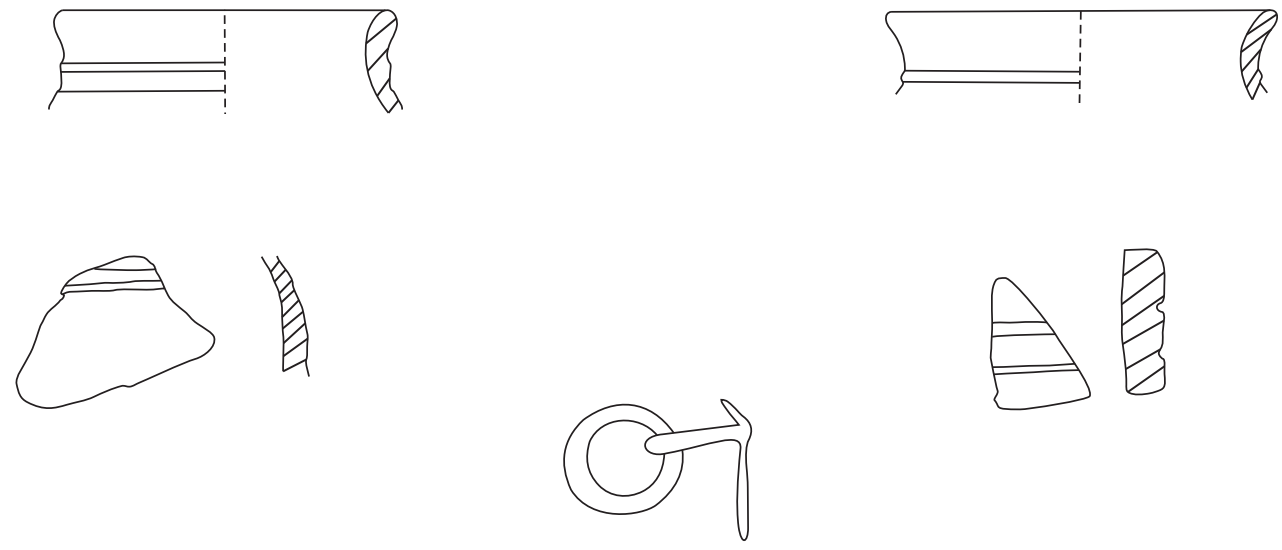
$3 \mathrm{~cm}$ 


\section{Complexul N041}
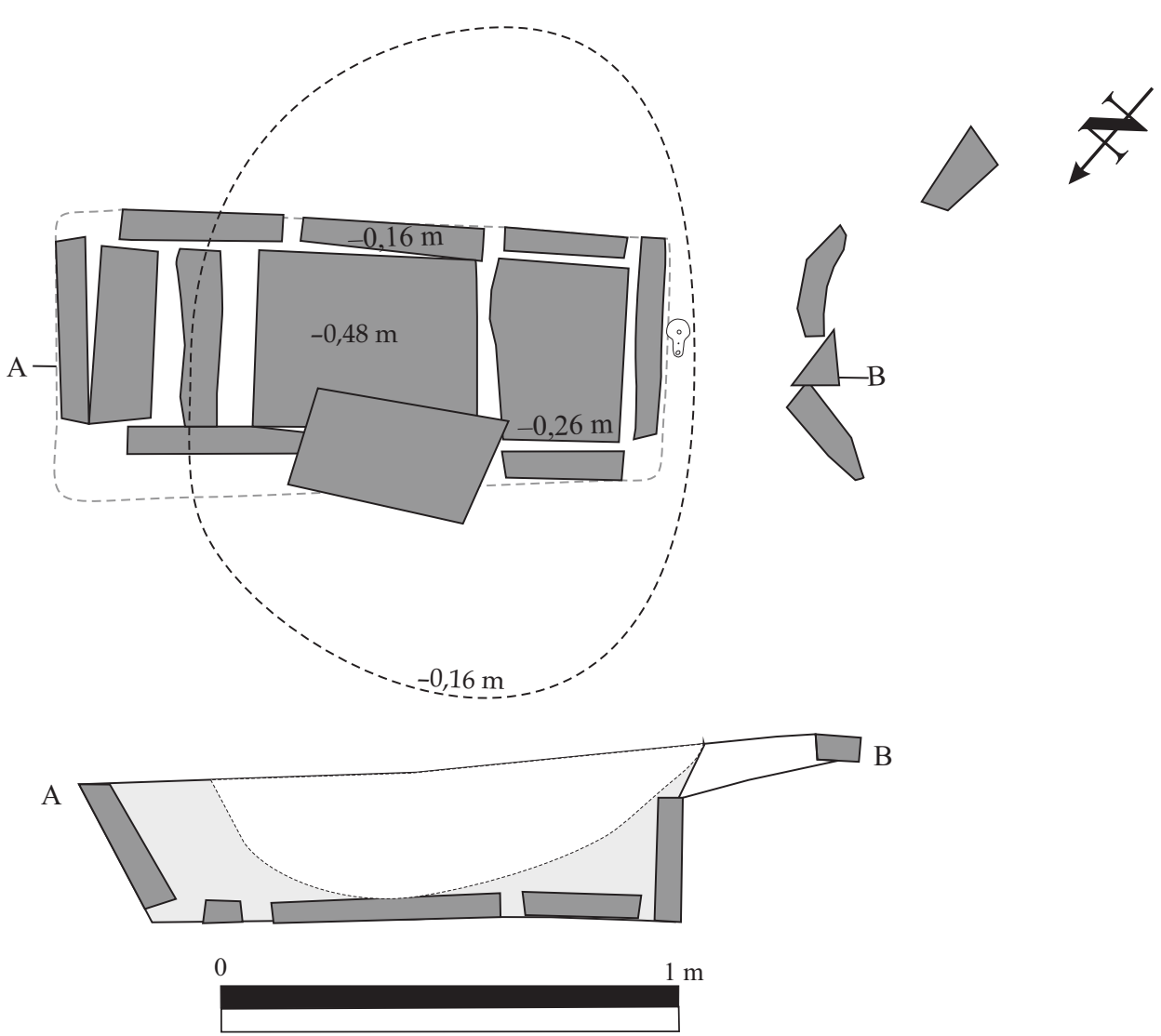

Camera rectangulară din cărămidă (etajul inferior)

1-j Conturul gropilor mormântului

$\square$ Sedimentul (galben-maroniu) de umplutură al gropii

:-i Conturul gropii de intervenţie antropică

Cărămidă

Opaiţ

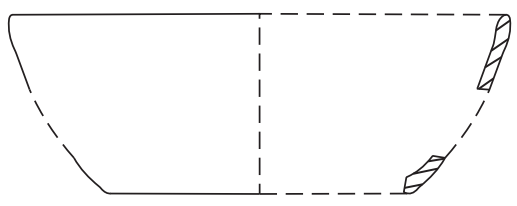

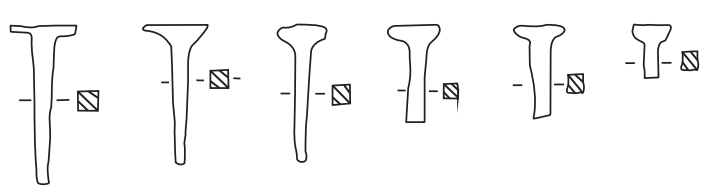
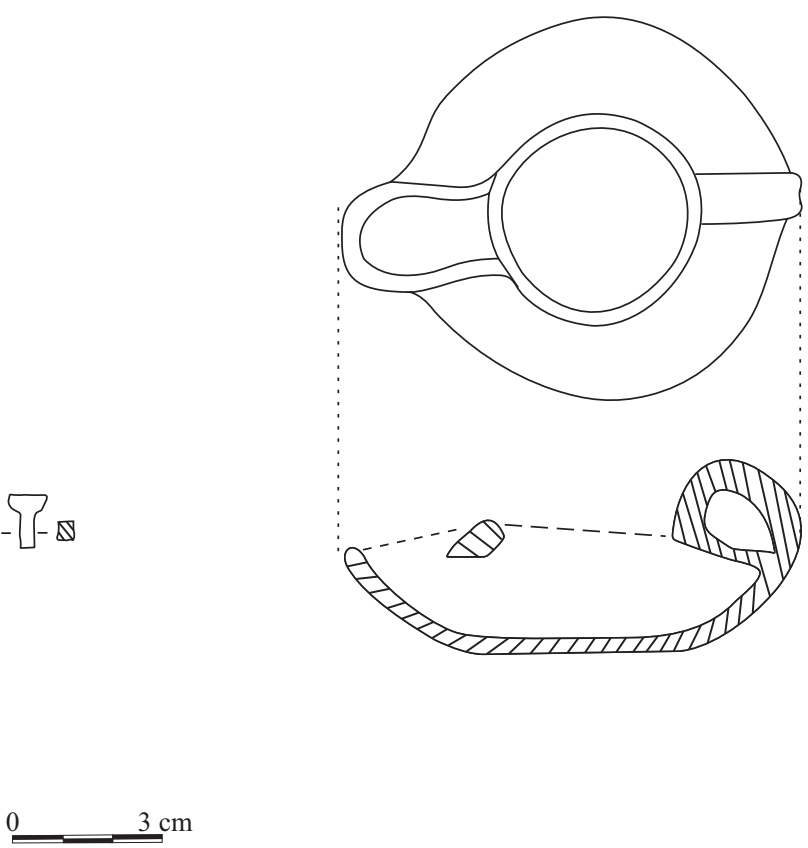


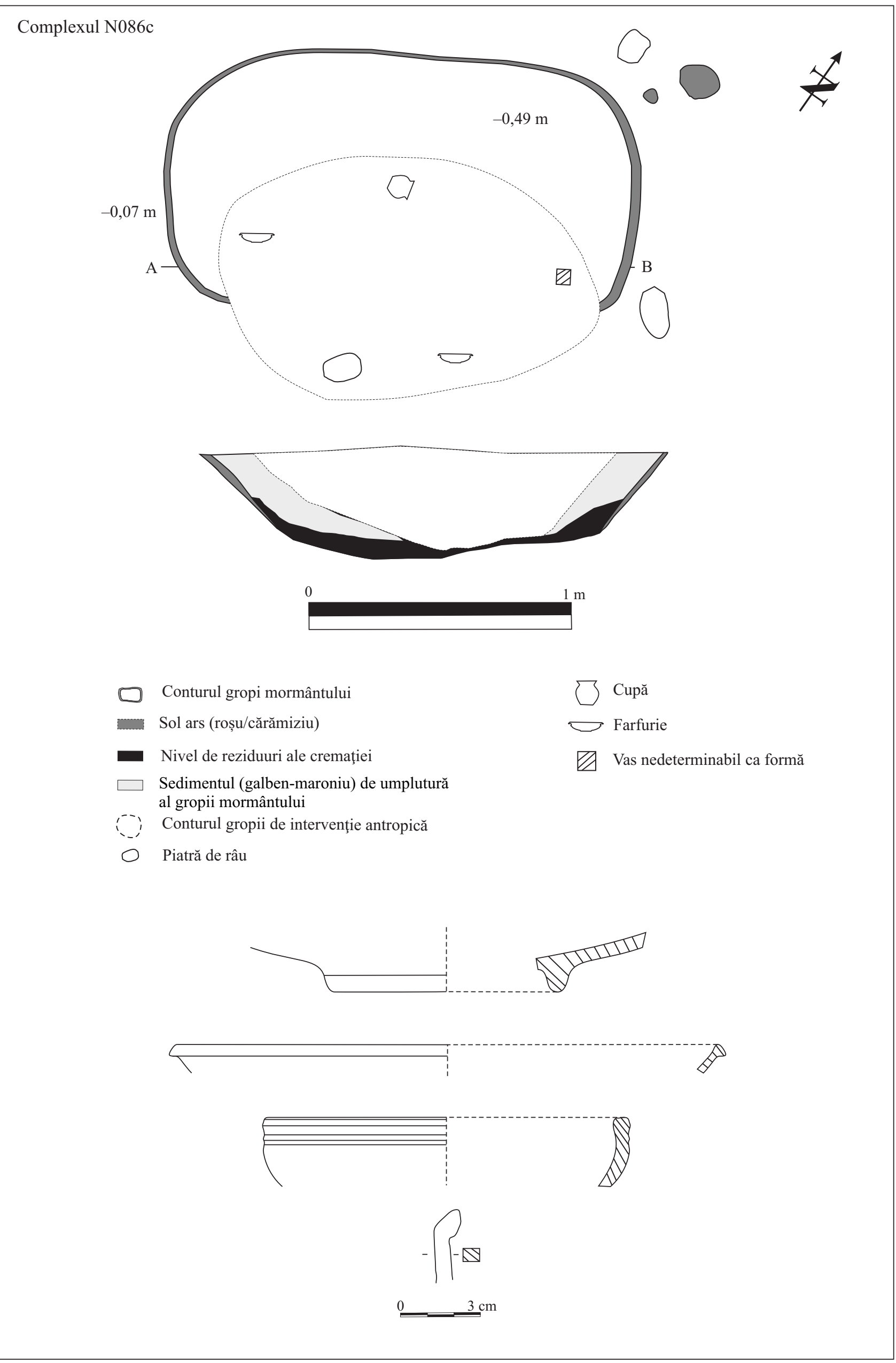

PI. XXIII 
Complex N133
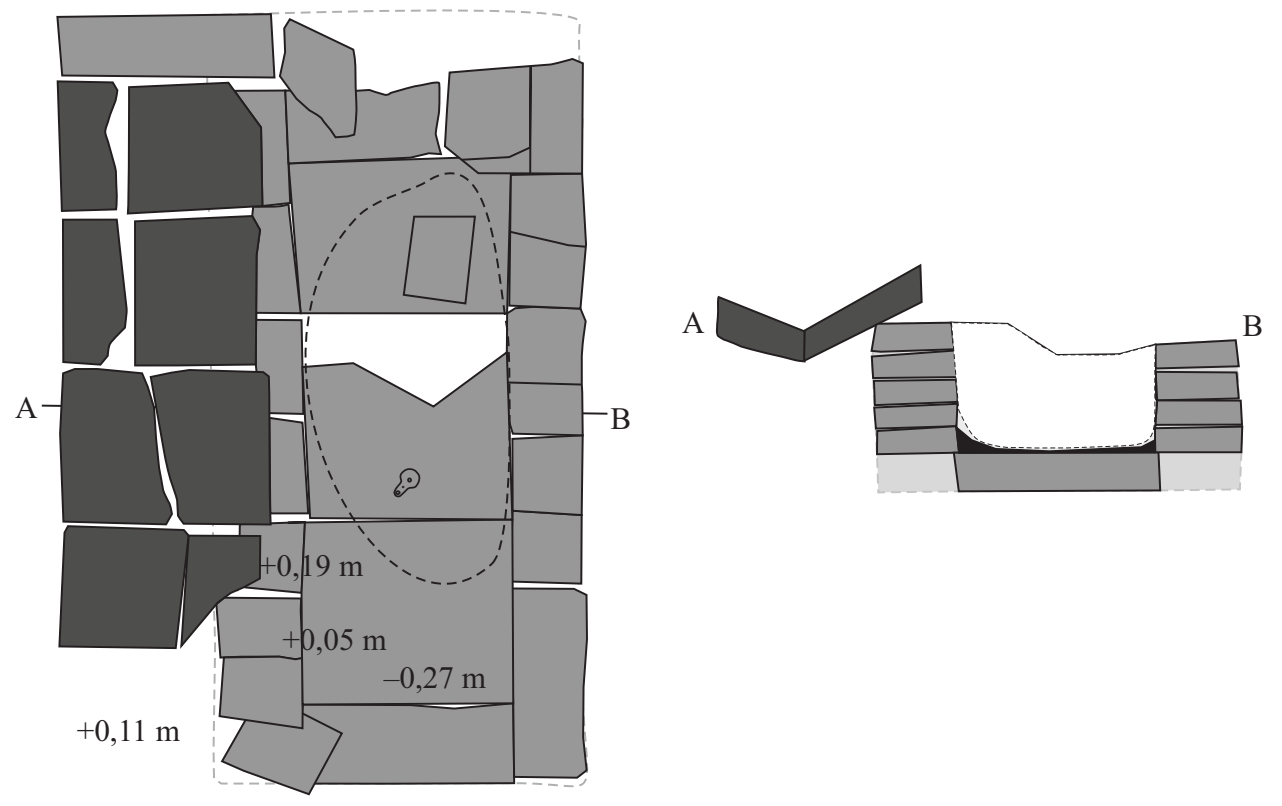

0 $1 \mathrm{~m}$

Camera rectangulară din cărămidă (etajul inferior și cărămizi din treaptă, pe latura de nord-vest)

Conturul gropii mormântului

- Nivel de reziduuri ale cremaţiei

Sedimentul (galben-maroniu) de umplutură al gropii mormântului

$\square$ Sediment lutos (galben)

-, Conturul gropii de intervenţie antropică

Cărămidă

$\odot$ Opaiț

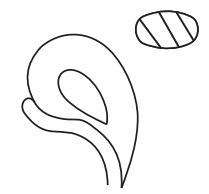




\section{Complexul N135}
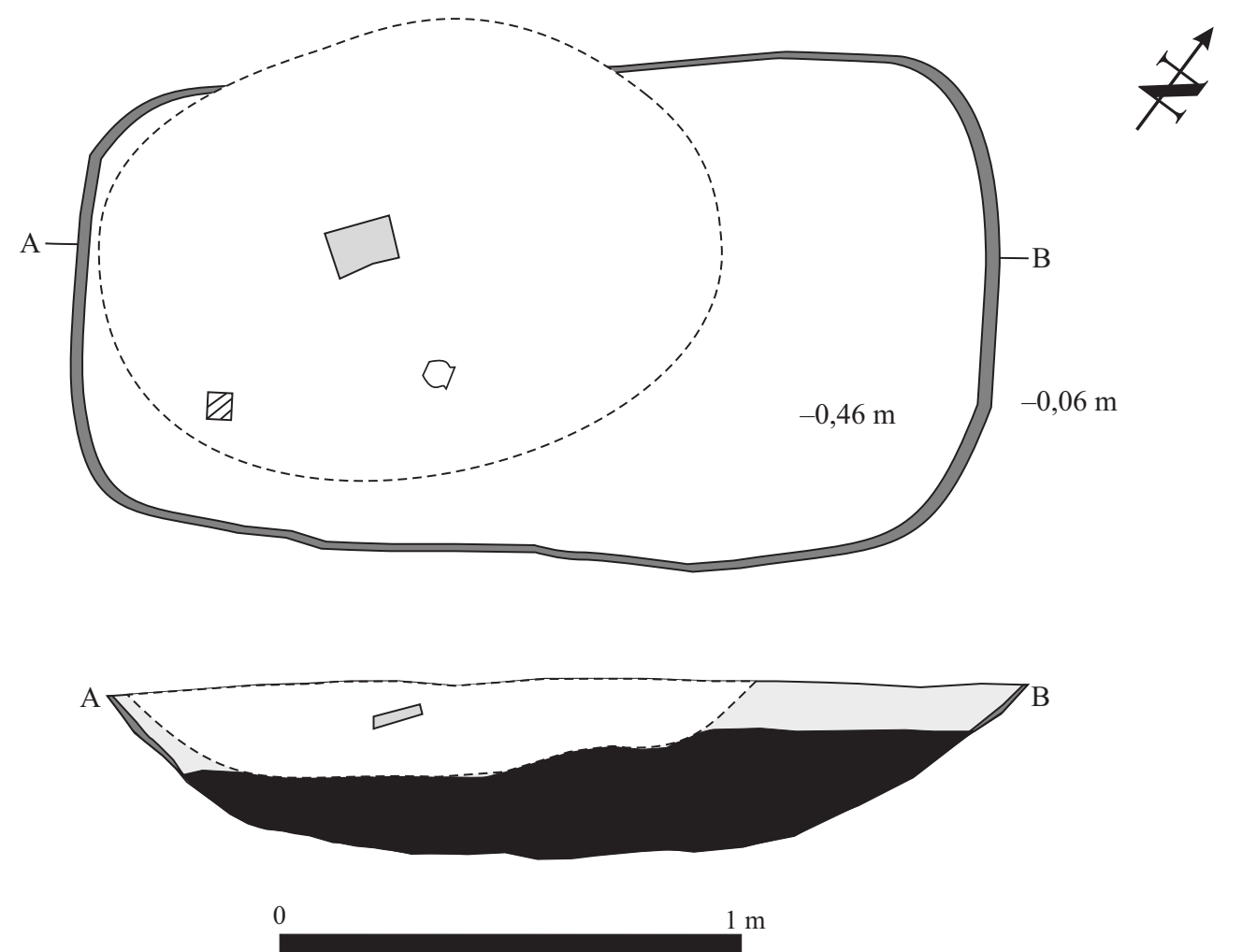

$\square$ Conturul gropii mormântului

Sol ars (roșu/cărămiziu)

$\square$ Cupă

Nivel de reziduuri ale cremaţiei

Sedimentul (galben-maroniu) de umplutură al

Vas nedeterminabil ca formă gropii mormântului

-) Conturul gropii de intervenţie
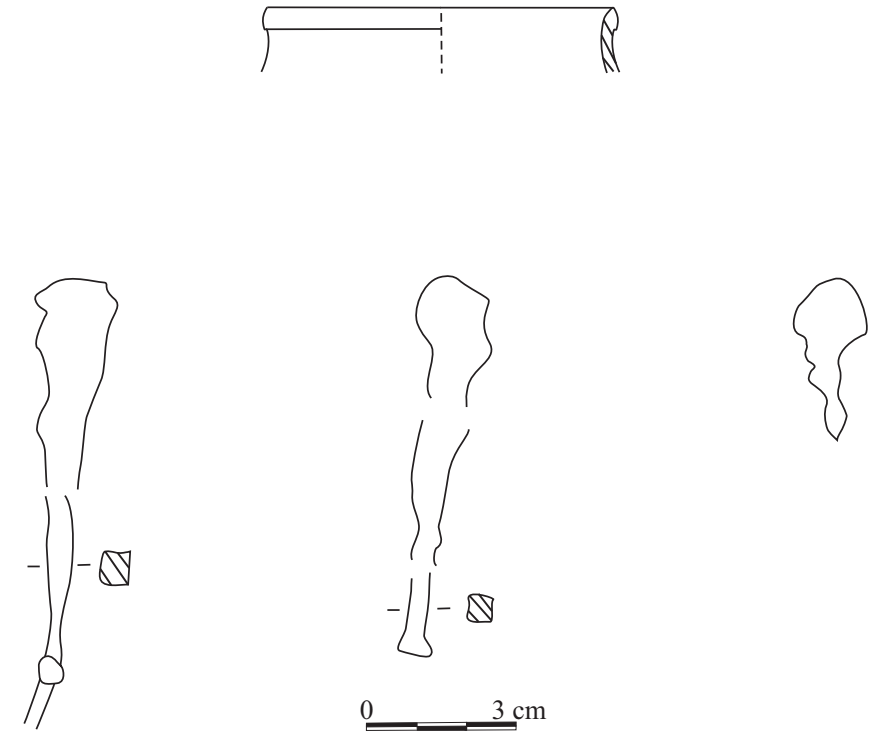

PI. XXV 
Complexul N141
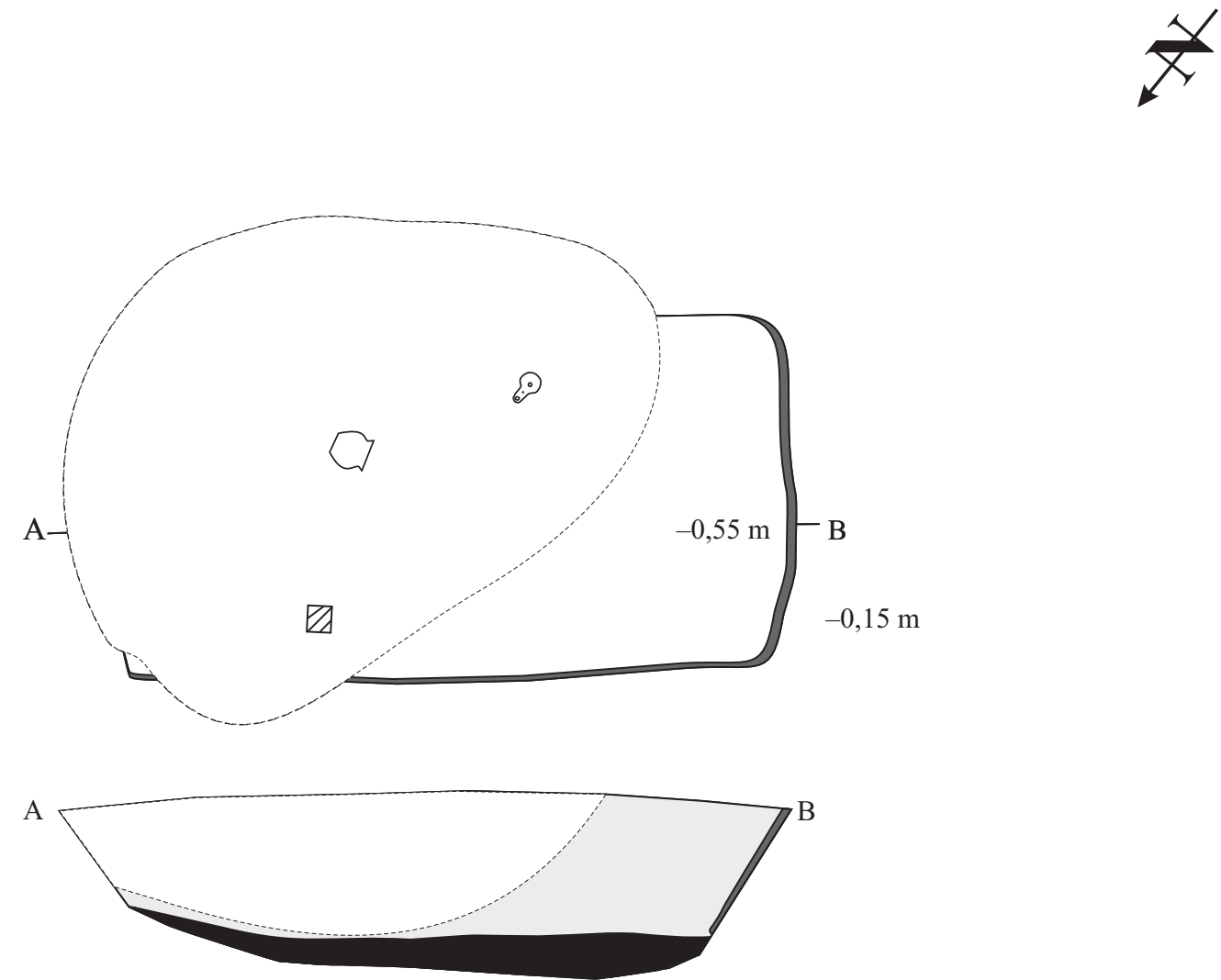

0 $1 \mathrm{~m}$

Conturul gropii mormântului

Sol ars (roșu/cărămiziu)

- Nivel de reziduuri ale cremaţiei

Sedimentul (galben-maroniu) de umplutură al gropii mormântului

( ) Conturul gropii de intervenţie antropică $\square$ Cupă

$\odot$ Opaiţ

$\square$ Fragment ceramic

- 11111111110
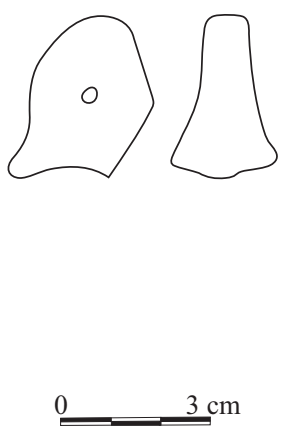

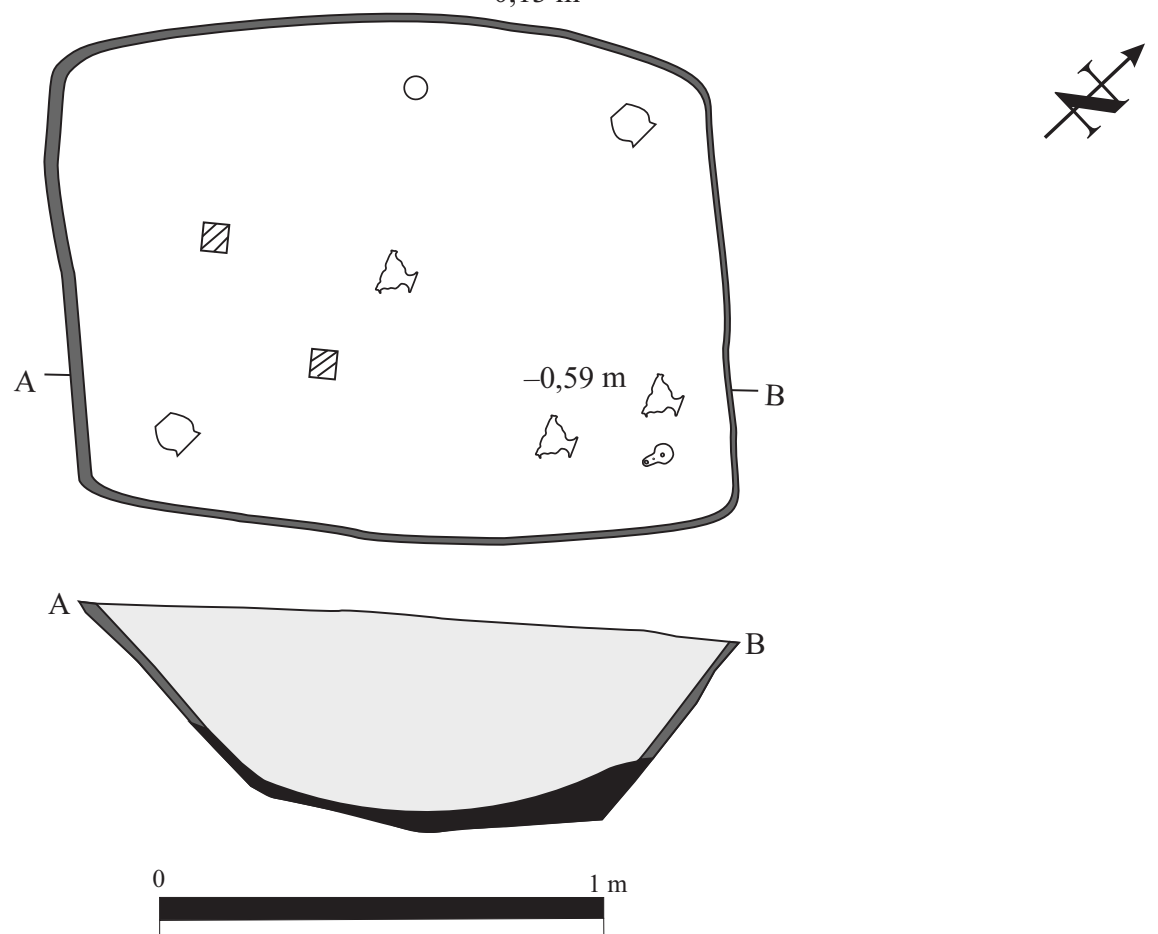

$\square$ Conturul gropii mormântului

Sol ars (roșu/cărămiziu)

Sedimentul (galben-maroniu)

de umplutură al gropii

- Nivel de reziduuri ale cremaţiei
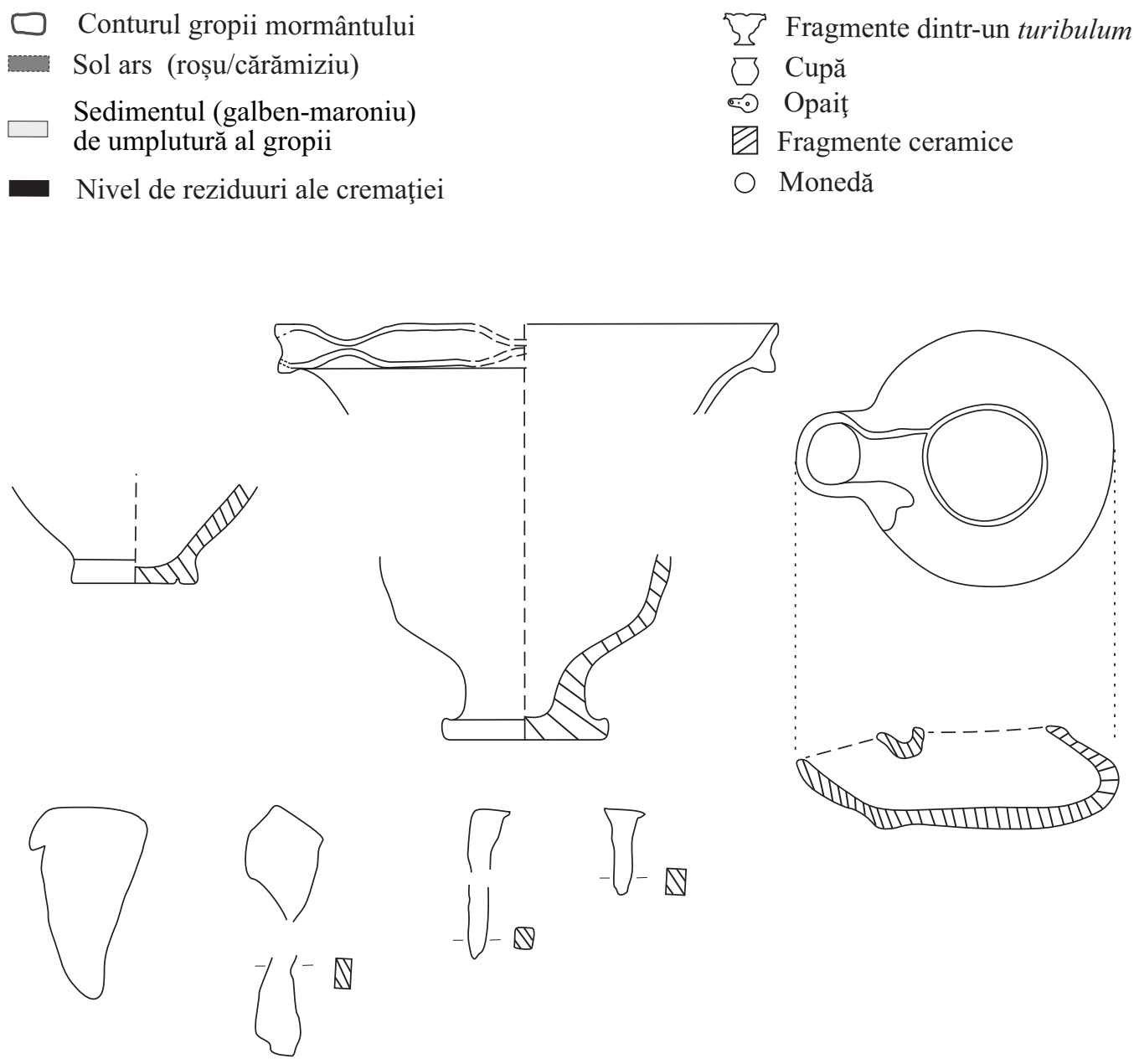

$=3 \mathrm{~cm}$ 


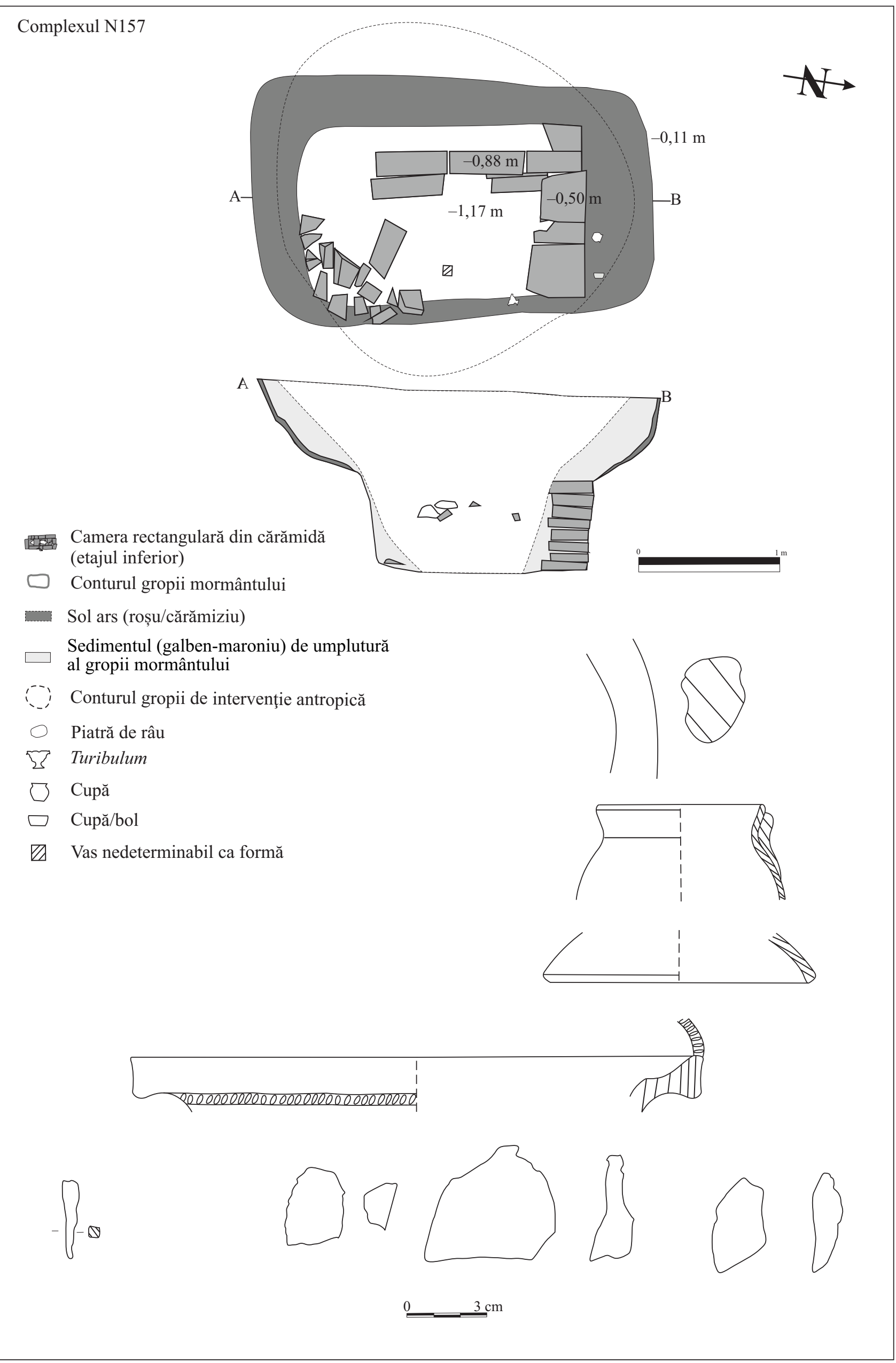

PI. XXVIII 
Complexul N183
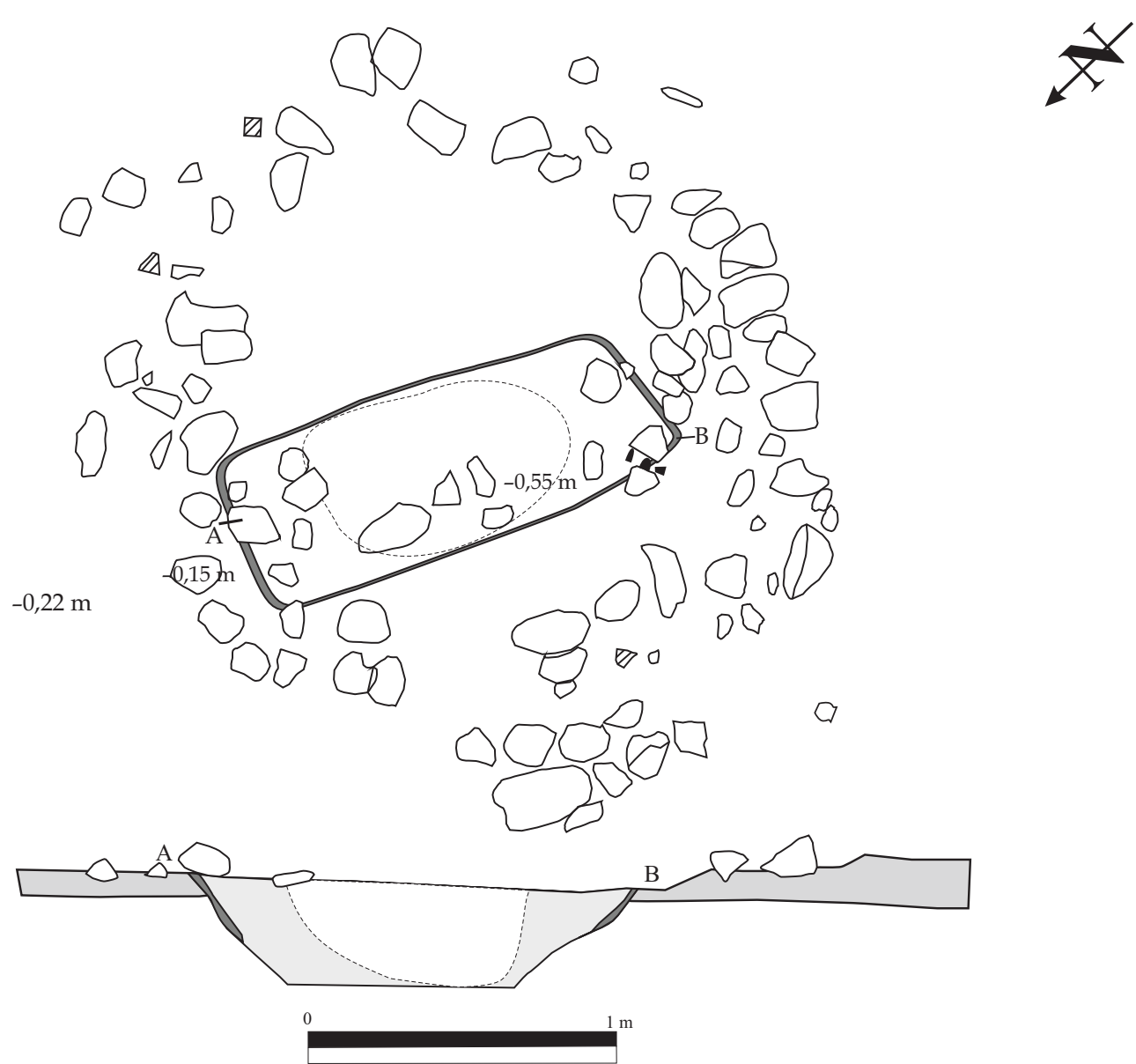

Conturul gropii mormântului

Sol ars (roșu/cărămiziu)

Sedimentul (galben-maroniu) de umplutură

Cupă/bol?

al gropii mormântului

Amenajare circulară din piatră de râu de tipul „ring”

Sediment brun-negricios

Conturul gropii de intervenţie antropică

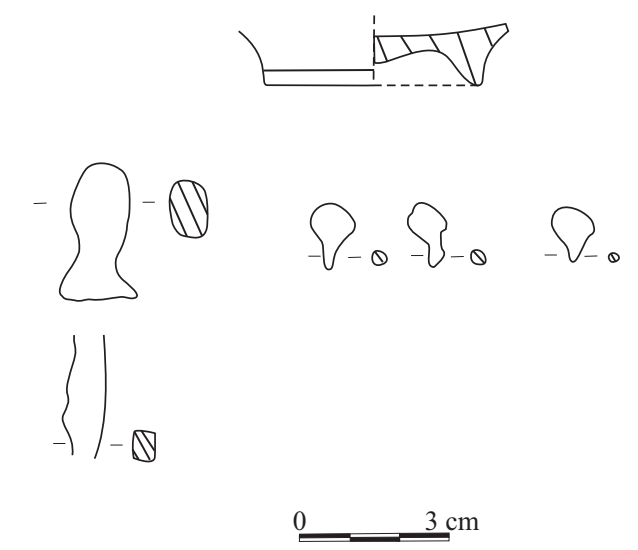

$\oslash \quad$ Fragmente ceramice

PI. XXIX 


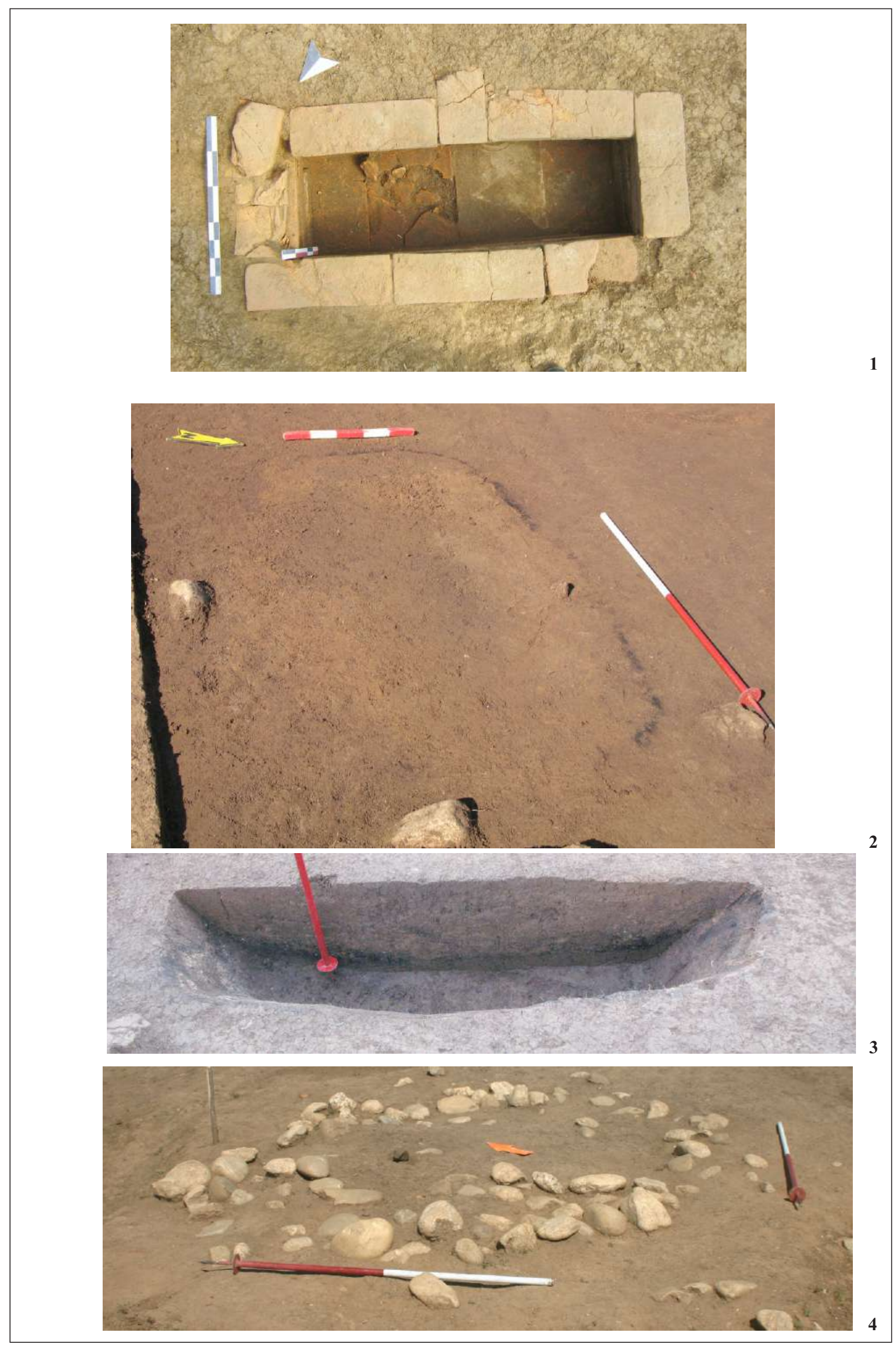

PI. XXX 


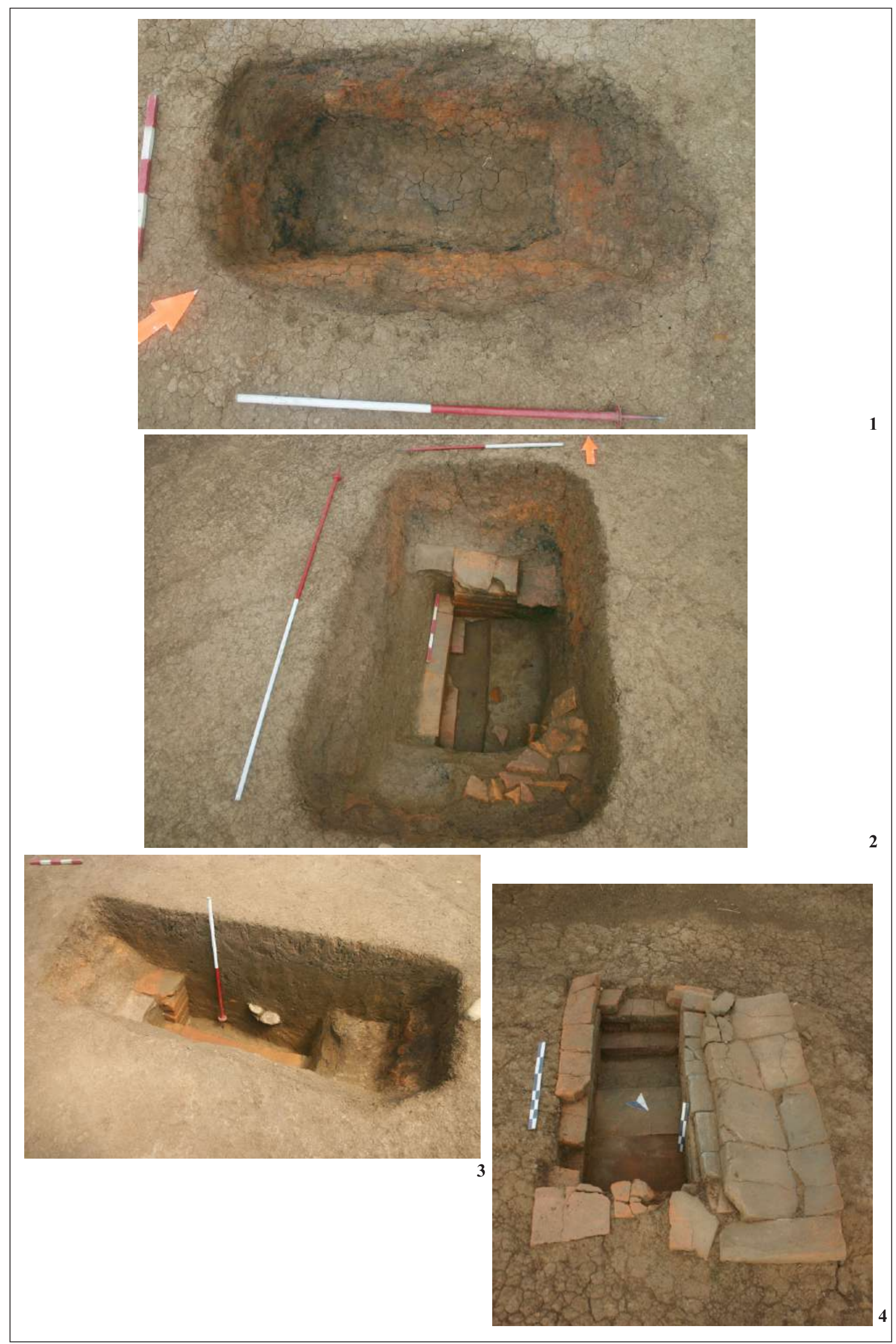

Pl. XXXI 


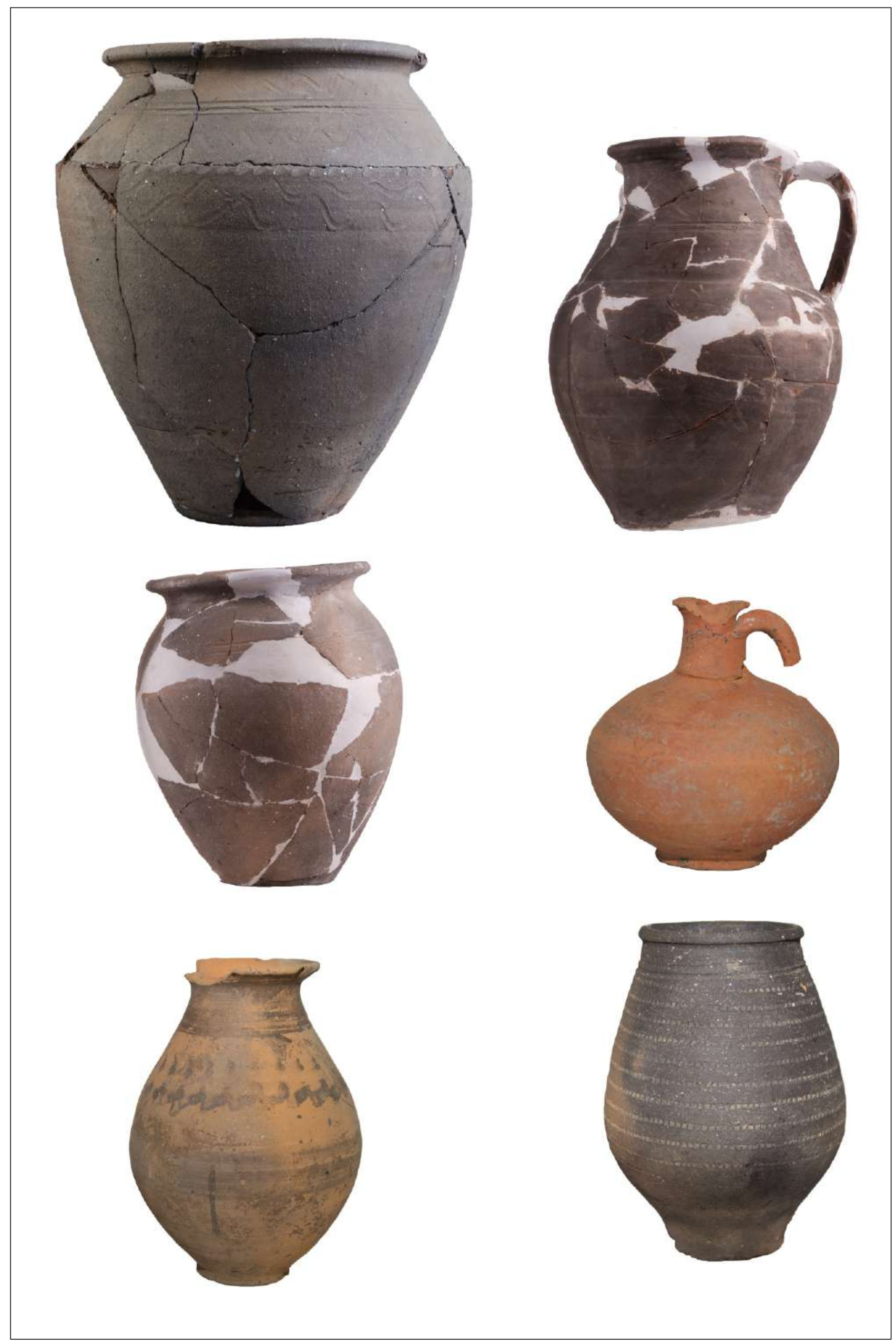

Pl. XXXII 


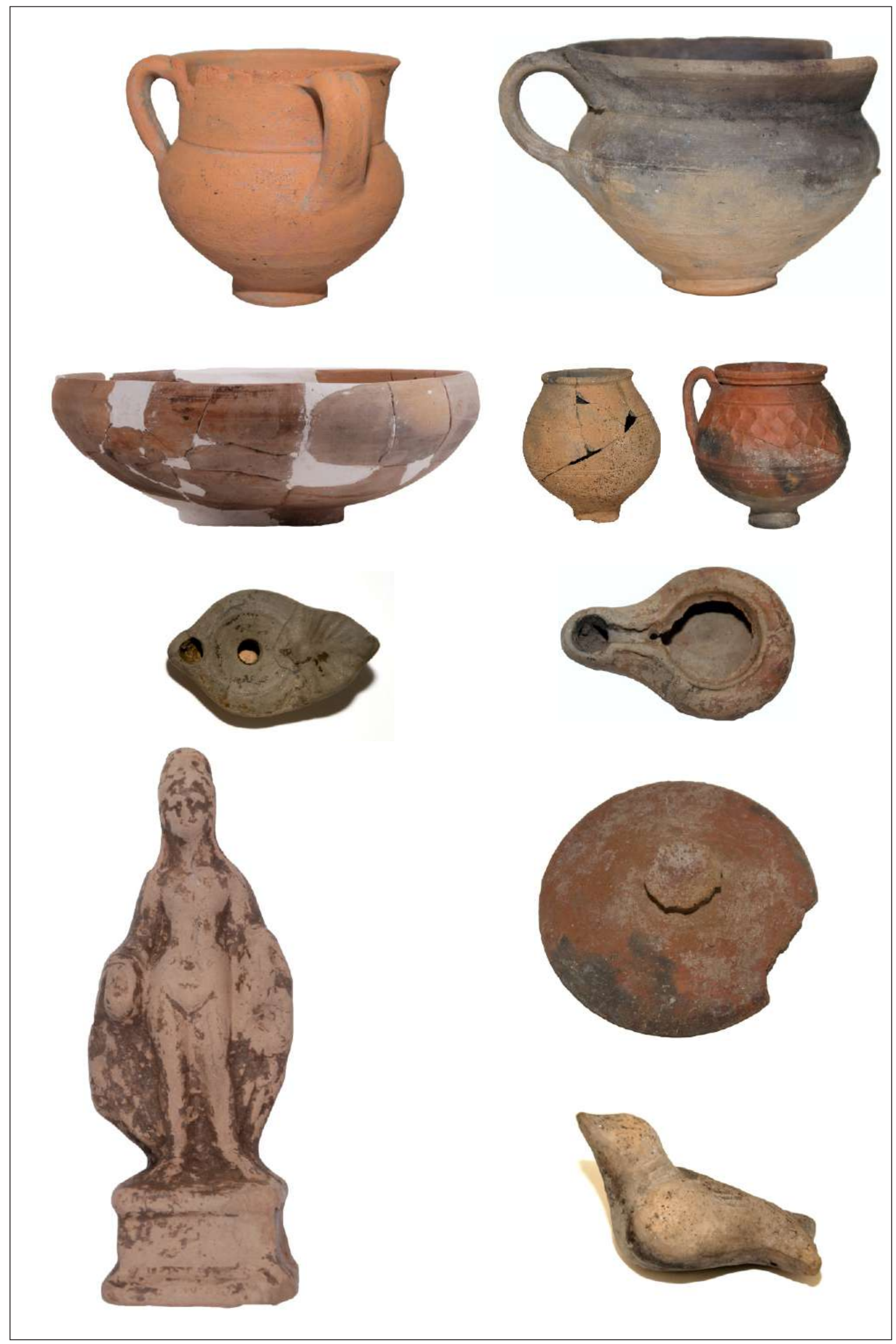

PI. XXXIII 


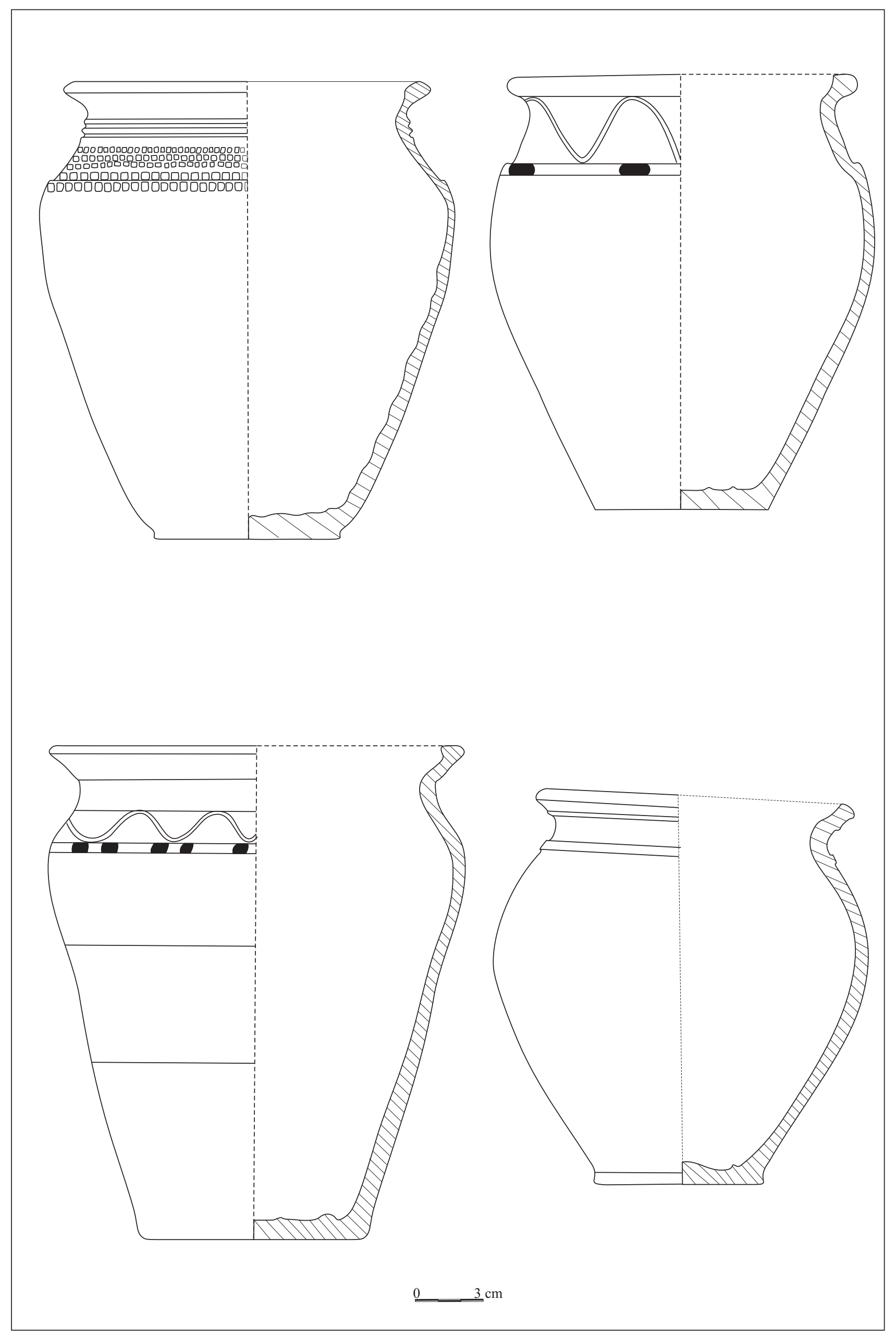

PI. XXXIV 

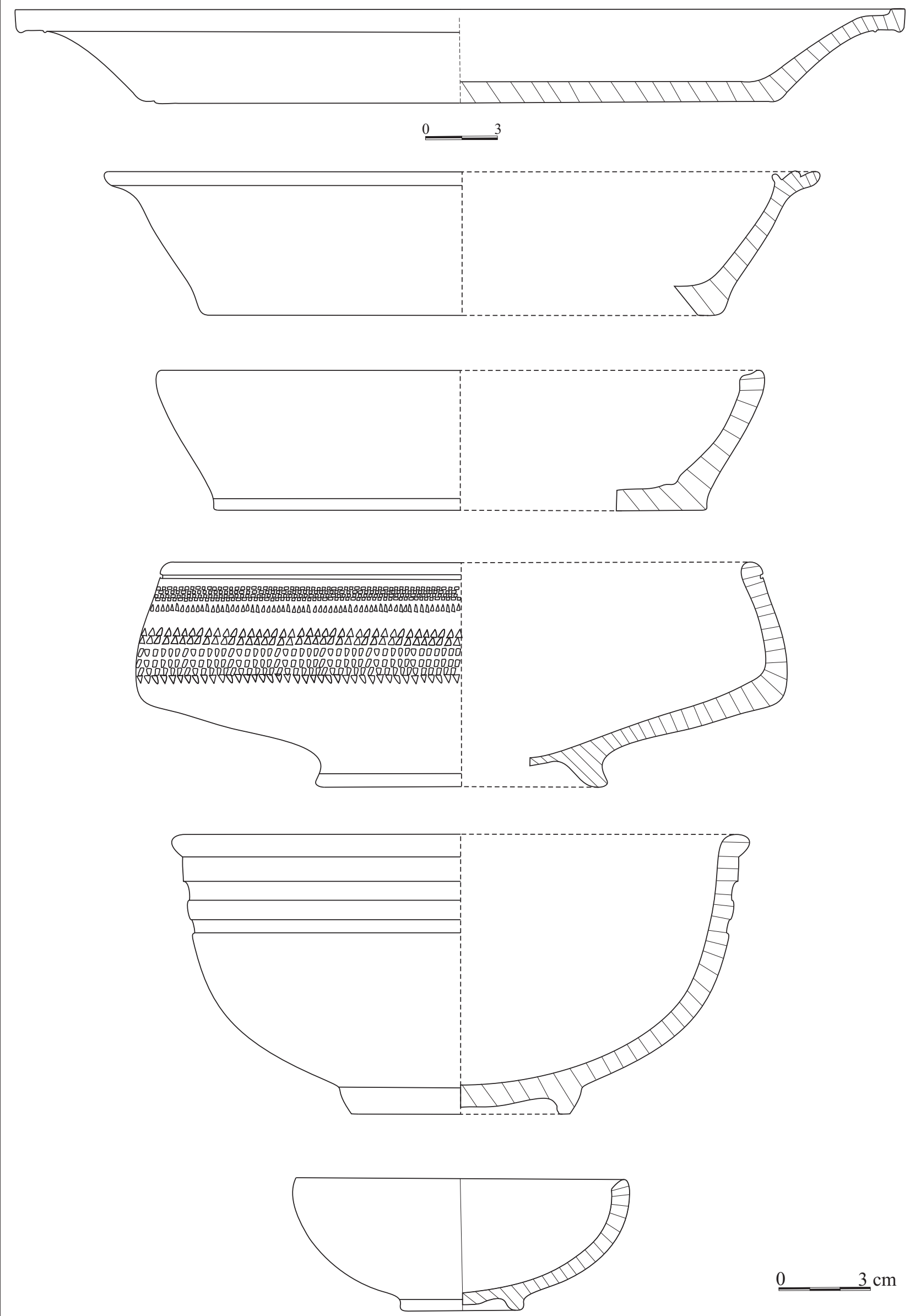

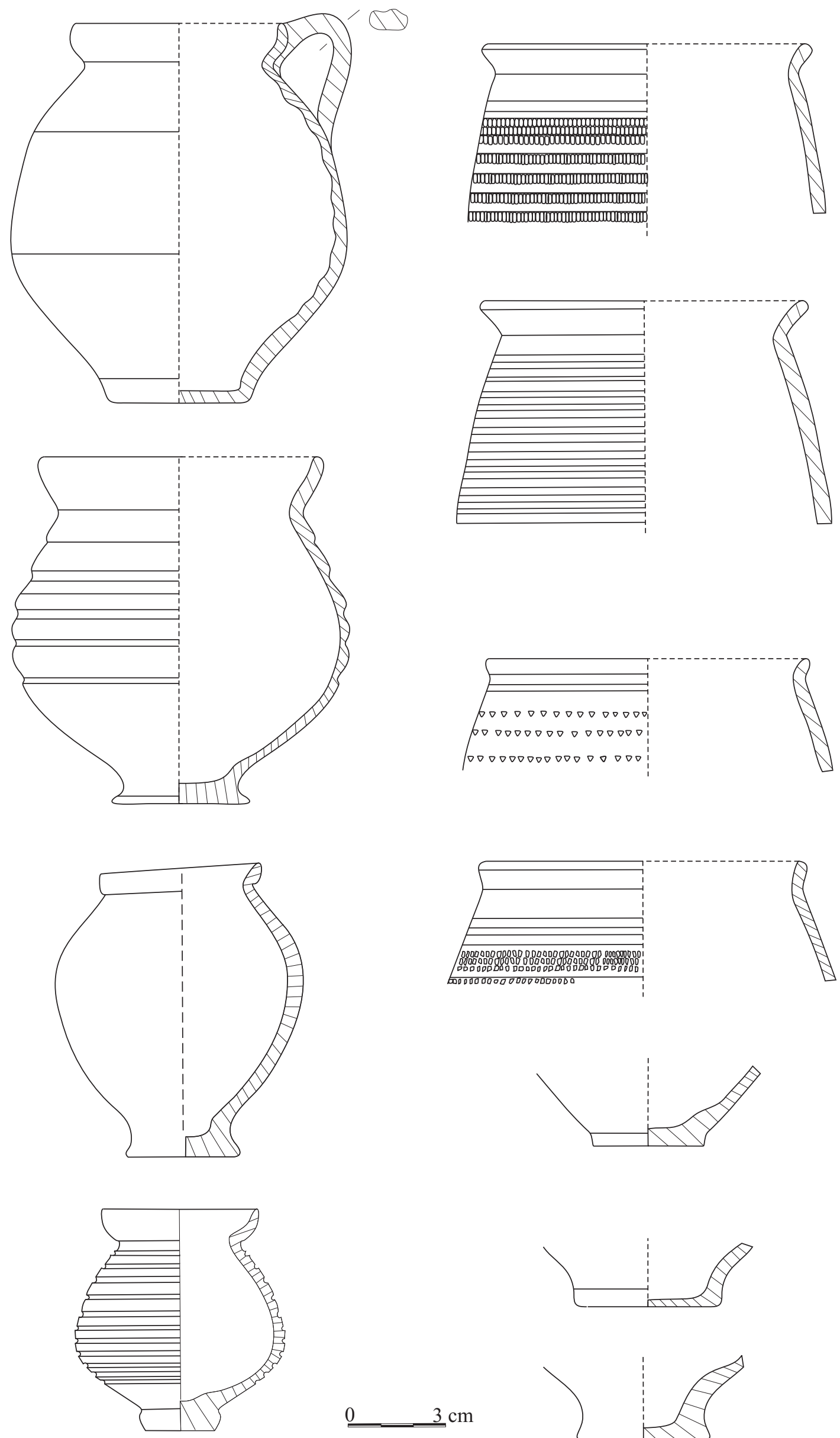

0

$3 \mathrm{~cm}$
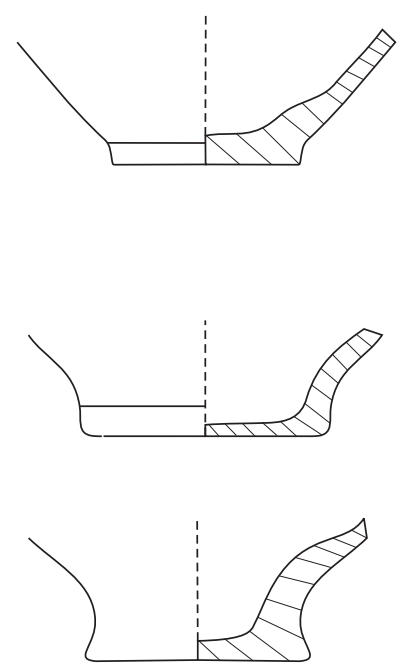

PI. XXXVI 

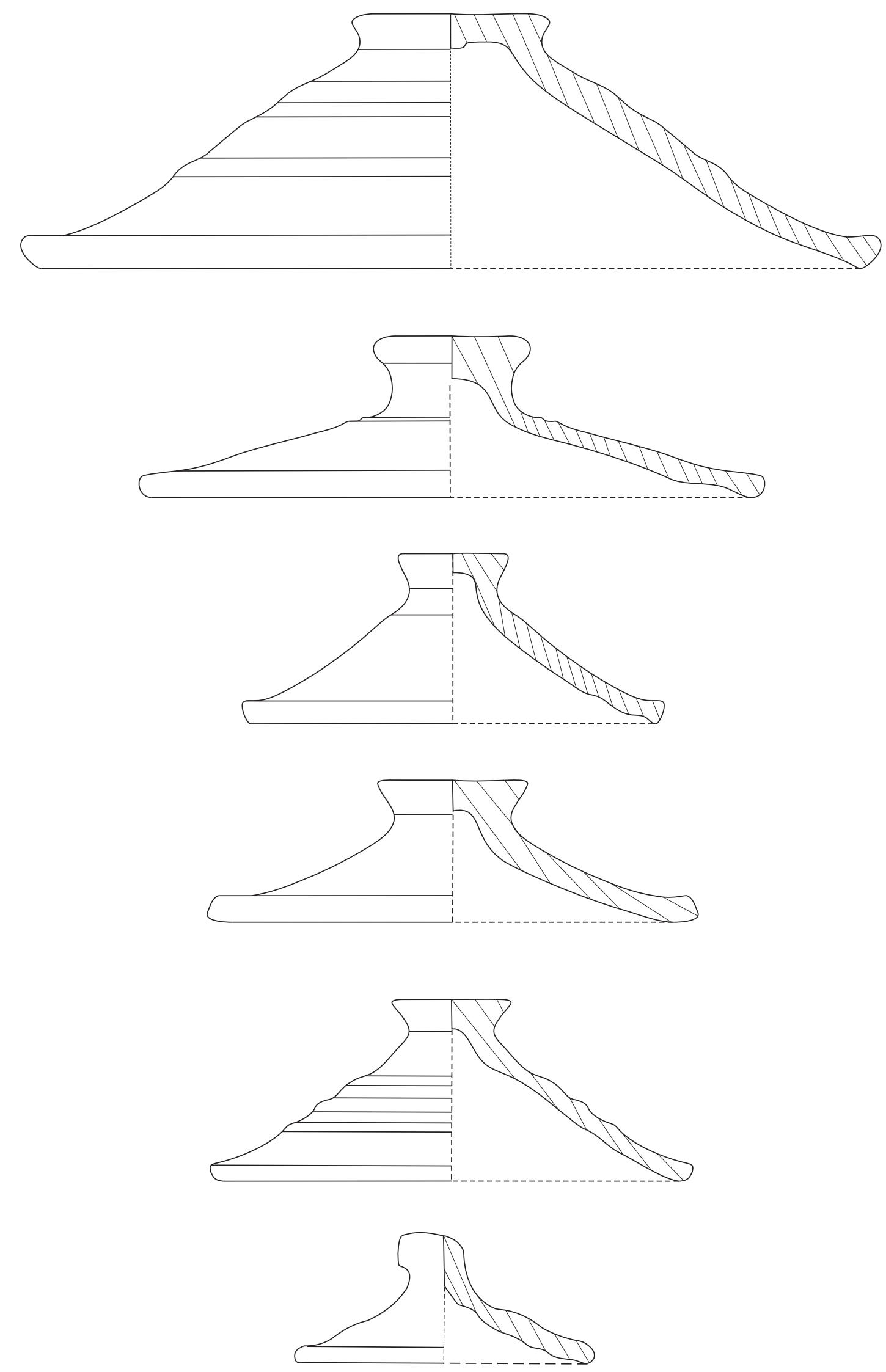

$0 \quad 3 \mathrm{~cm}$

PI. XXXVII 


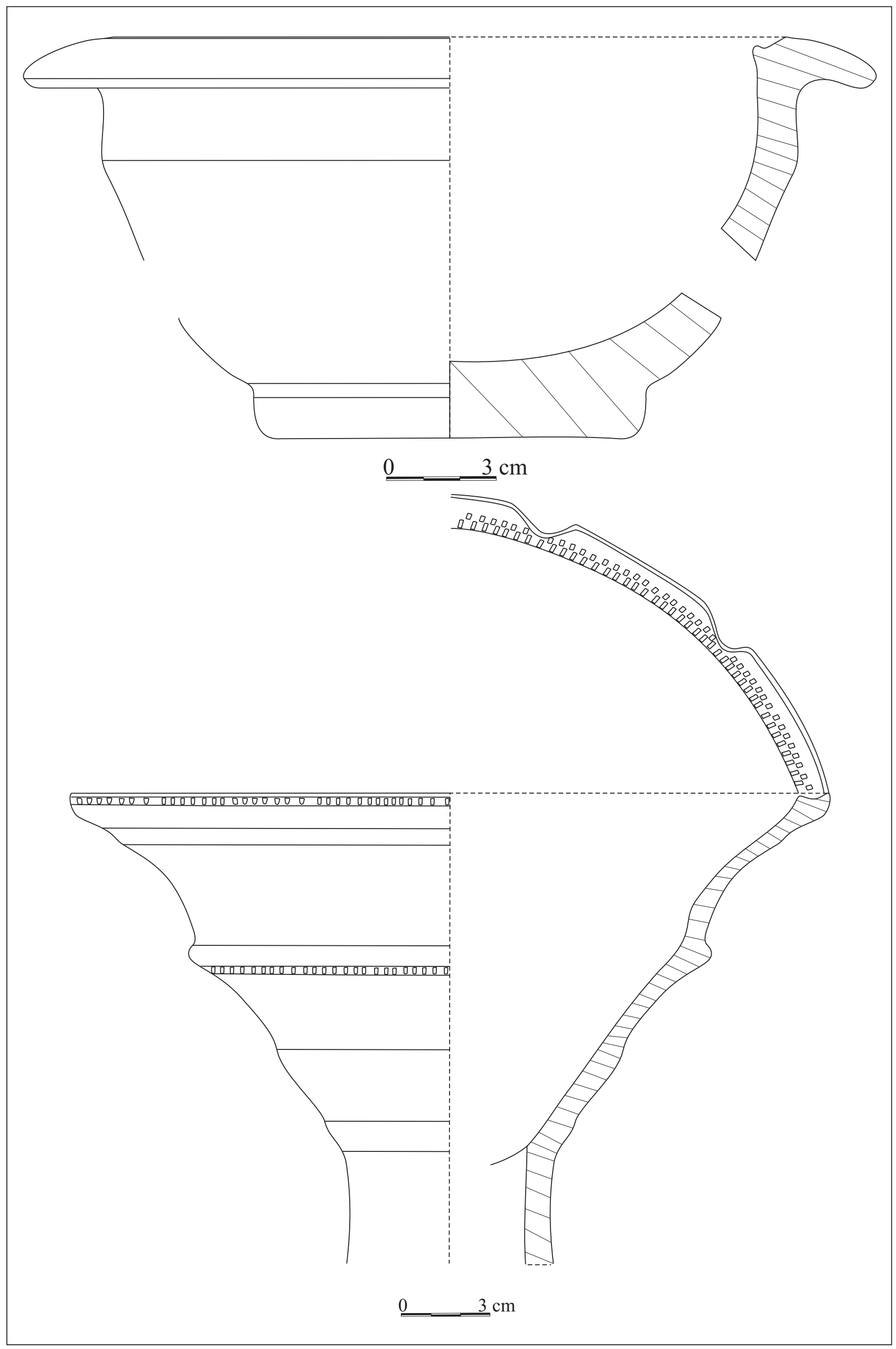

PI. XXXVIII 

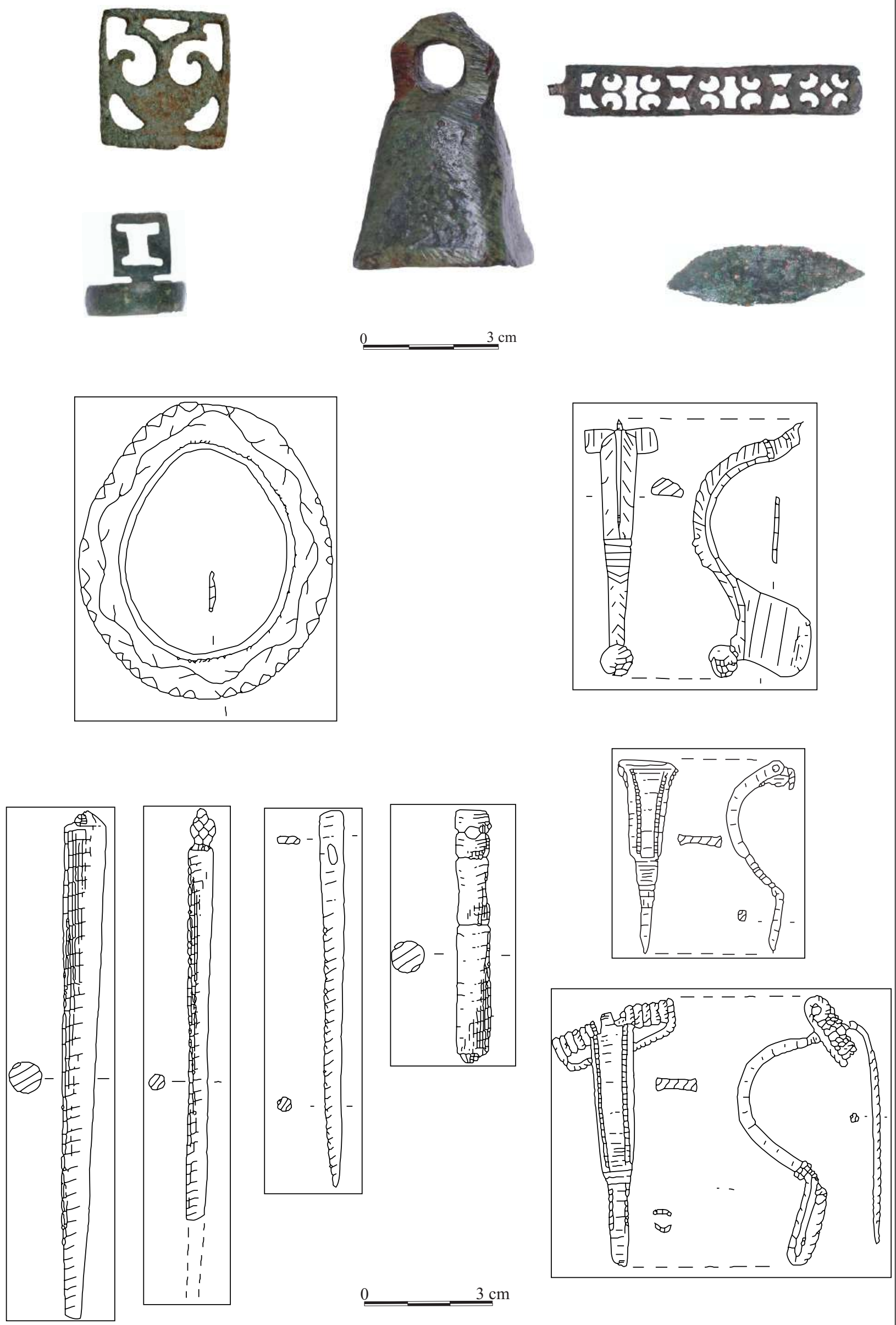

PI. XXXIX 


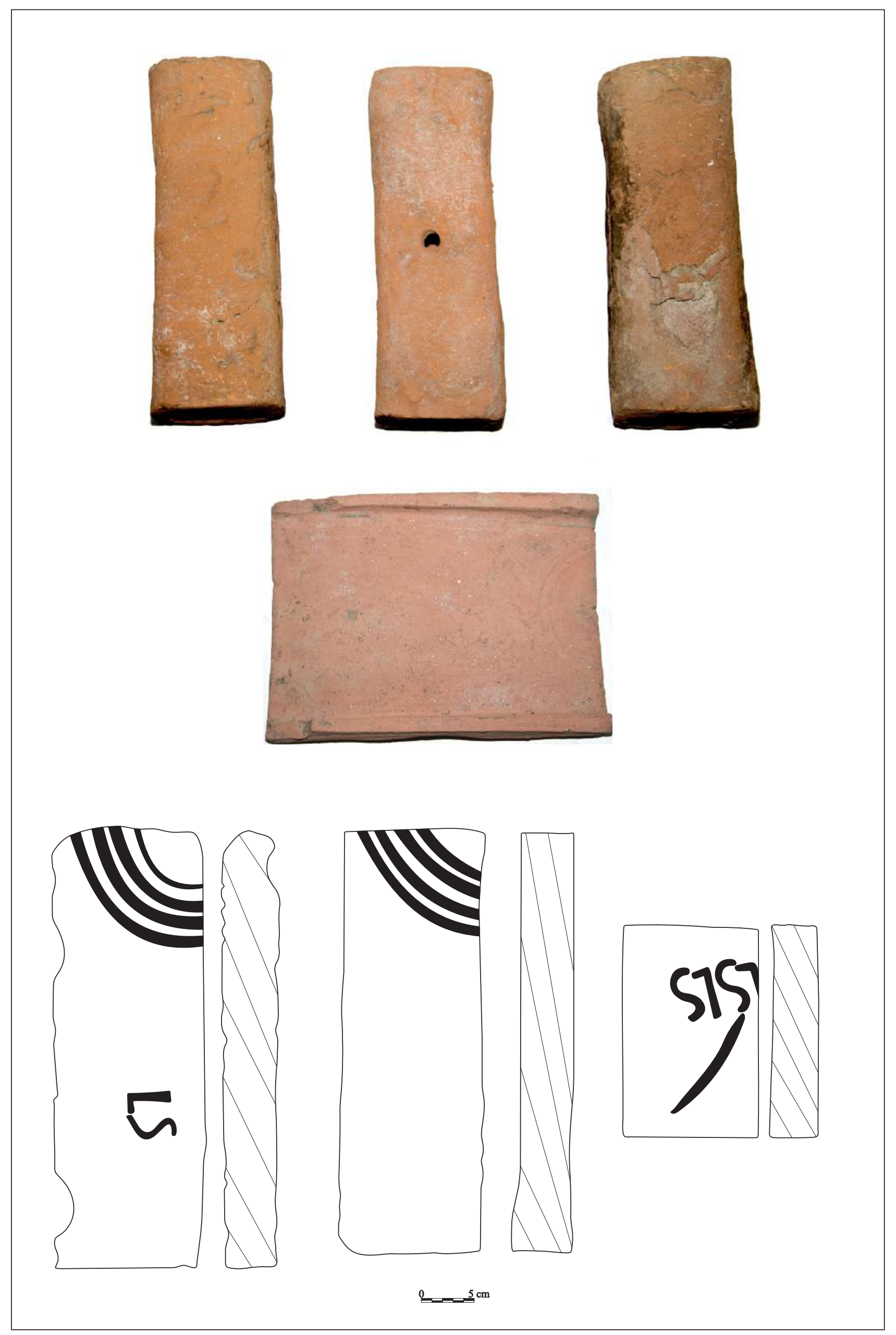

PI. XL 